\title{
Evaluation of Growth and Survival of Hardwood Trees on Brown and Gray Sandstone
}

\author{
Lindsay M. Wilson-Kokes \\ West Virginia University
}

Follow this and additional works at: https://researchrepository.wvu.edu/etd

\section{Recommended Citation}

Wilson-Kokes, Lindsay M., "Evaluation of Growth and Survival of Hardwood Trees on Brown and Gray Sandstone" (2013). Graduate Theses, Dissertations, and Problem Reports. 3620.

https://researchrepository.wvu.edu/etd/3620

This Thesis is protected by copyright and/or related rights. It has been brought to you by the The Research Repository @ WVU with permission from the rights-holder(s). You are free to use this Thesis in any way that is permitted by the copyright and related rights legislation that applies to your use. For other uses you must obtain permission from the rights-holder(s) directly, unless additional rights are indicated by a Creative Commons license in the record and/ or on the work itself. This Thesis has been accepted for inclusion in WVU Graduate Theses, Dissertations, and Problem Reports collection by an authorized administrator of The Research Repository @ WVU. For more information, please contact researchrepository@mail.wvu.edu. 


\title{
Evaluation of Growth and Survival of
}

\section{Hardwood Trees on Brown and Gray Sandstone}

\author{
Lindsay M. Wilson-Kokes \\ Thesis submitted to the College of Agriculture, Natural Resources and Design \\ at West Virginia University \\ in partial fulfillment for the requirements \\ for the degree of \\ Master of Science \\ In \\ Plant and Soil Sciences
}

\author{
Committee: \\ Jeffrey G. Skousen, Ph.D., Chair \\ Louis M. McDonald, Ph.D. \\ Jingjing Liang, Ph.D. \\ Division of Plant and Soil Sciences \\ West Virginia University \\ Morgantown, WV
}

2013

Keywords: brown sandstone, gray sandstone, Forestry Reclamation Approach, compaction, bark mulch, foliar nutrient concentration. 


\title{
ABSTRACT
}

Evaluation of Growth and Survival of Hardwood Trees on Brown and Gray Sandstone

\author{
Lindsay M. Wilson-Kokes
}

Deciduous forests in the Appalachian region have been greatly disrupted due to surface coal mining since the 1930's. After the passage of the Surface Mining Control and Reclamation Act (SMCRA) in 1977, coal mine operators began planting a variety of grasses and legumes as a fast and economical way to re-establish a permanent vegetative cover in order to meet erosion and site stabilization requirements. However, soil compaction and competitive forage species have arrested the re-colonization of native hardwood tree species on these reclaimed sites. In an effort to evaluate tree growth on selected spoils and determine the effects of compaction, three 2.8-ha experimental plots were established at Catenary Coal's Samples Mine in Kanawha County, West Virginia. Two plots were constructed of weathered brown sandstone and the third plot was constructed of un-weathered gray sandstone. Half of each plot was compacted while the other half was non-compacted. Each plot was hydroseeded with a low competition herbaceous cover and planted with eleven hardwood tree species. Soil chemical properties and tree growth have been measured each year since 2005. After eight growing seasons, average tree volume index was nearly ten times greater for trees grown in the brown sandstone treatments, $3853 \mathrm{~cm}^{3}$, compared to $407 \mathrm{~cm}^{3}$ in gray sandstone. Trees growing on compacted treatments had a lower mean volume index, $2281 \mathrm{~cm}^{3}$, than trees growing on non-compacted treatments, $3899 \mathrm{~cm}^{3}$. Average $\mathrm{pH}$ of brown sandstone was 5.2 to 5.7 while gray sandstone was 7.9. The gray sandstone has continued to resist breakdown and had much lower fines content (40\%) compared to brown sandstone $(70 \%)$, which influenced nutrient and water-holding capacity. After eight years, brown sandstone showed significantly greater tree growth and survival, and is a more suitable topsoil substitute than gray sandstone on this site.

The second study site was a 2.8-ha experimental plot established at Arch Coal's Birch River mine in Webster County, WV. Half of the plot was constructed of weathered brown sandstone and half was constructed of unweathered gray sandstone. Bark mulch was applied to a small area covering both sandstone types and the ends of the plot were hydroseeded with a low competition herbaceous cover, resulting in eight soil treatments. The plot was then planted with twelve hardwood tree species and soil chemical properties and tree growth have been measured each year since 2008. After six growing seasons, average tree volume index was consistently higher for trees grown on brown sandstone $\left(5,333 \mathrm{~cm}^{3}\right)$ compared to gray sandstone $\left(3,031 \mathrm{~cm}^{3}\right)$. Trees planted on treatments with bark mulch outperformed trees on non-mulched treatments (volume index of $6,187 \mathrm{~cm}^{3}$ vs. 4,194 $\mathrm{cm}^{3}$ ). Hydroseeding with a tree-compatible mix produced greater ground cover $(80 \%$ vs. $45 \%)$ and resulted in greater tree volume index than nonhydroseeded areas $\left(5,809\right.$ vs. $\left.3,403 \mathrm{~cm}^{3}\right)$. Soil chemical properties of mulched treatments showed little similarity to those of the underlying sandstone, which suggests the bark mulch overcame the poor characteristics of the gray sandstone parent material for tree growth. The average $\mathrm{pH}$ of brown sandstone mine soils was 5.0 to 5.4 and gray sandstone mine soils averaged pH 6.9 to 7.7. The non-mulched gray sandstone material has resisted breakdown and weathering, and still had a high $\mathrm{pH}$ and low percentage of fines after six years resulting in slow growth of trees. The mulch 
treatment on gray sandstone resulted in tree growth similar to brown sandstone alone. After six years, brown sandstone showed about double the growth of trees compared to gray sandstone, and bark mulch was a successful amendment that improved tree growth.

Tree leaves were also collected from three tree species growing on non-hydroseeded treatments at the Birch River mine for nutrient analysis and compared to tree leaves of the same species collected from an un-mined forest within the permitted area of the Birch River mine. Foliar phosphorus was lower in all three tree species on all non-hydroseeded treatments compared to trees growing in the unmined forest. Other nutrients such as potassium were consistently low on the gray sandstone for all species. While many trees growing on these soils, both reclaimed and unmined, are obtaining sufficient amounts of nutrients for growth, the brown sandstone demonstrated many foliar and soil values which were similar to values measured on the unmined forest while the gray treatment seemed to be providing fewer nutrients for adequate growth. 


\section{Acknowledgments}

I would like to start by thanking the members of my graduate committee. First, to my advisor, Jeff Skousen, who took a chance and gave me the amazing opportunity to pursue a higher level of education and to work as his graduate research assistant which allowed me to obtain research experience that is invaluable. Next, to Louis McDonald who saw my potential as a WVU graduate student and persistently encouraged me to apply to the Master's program. Then, to my third committee member, Jingjing Liang, whose dendrology course provided me with knowledge that aided in my graduate research. I thank you all and greatly appreciate the advice and support that each one of you have offered along the way.

Even with the support of an excellent graduate committee I could not have made this journey without the love and support of my dear husband Nathanael. Nathan not only provided emotional support but also helped collect soil samples, listened to countless presentations, and helped me photograph mine sites. For all of these things and so much more, I dedicate this thesis to you.

Moving on, I'd like to thank Joan Wright for all her help with the microwave digestion and analysis on the ICP. Next, to Drs. Phil Turk and George Merovich, thank you both for your help with my statistical analyses. I give a very big thanks to all the graduate students who helped me either with field work or simply helped me with other graduate school tasks; specifically Jessica Odenheimer, Carol Brown, Saraswati Poudel-Acharya, Mike Marra, and Calene Thomas.

I would also like to thank Paul Ziemkiewicz of West Virginia University for assistance in funding forestry research at WVU, Scott Eggerud of the US Office of Surface Mining as well as John McHale, Mitch Kalos, Jonathan Sanchez, and Jeff Andrews of Magnum Coal (now Patriot Coal, Inc.) for financial and construction support during this study. I especially thank Keith O'Dell for his abundant assistance to this study and allowing me to conduct my tree foliar nutrient analysis.

Lastly, I want to thank my parents for all their love and support for the past 29 years. They always encouraged me to pursue a higher education and I know that they were proud to have their only child become a first generation college graduate. I only wish that my father could be here to share my joy in earning a graduate degree. I love and miss you Dad. 


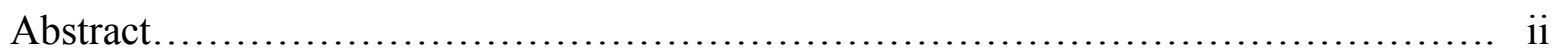

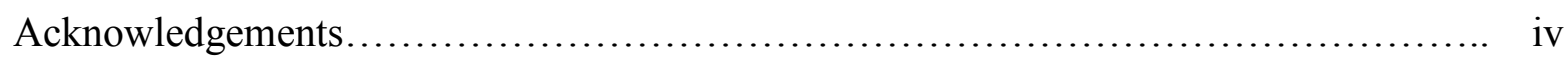

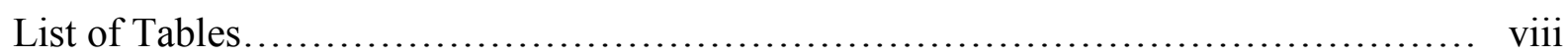

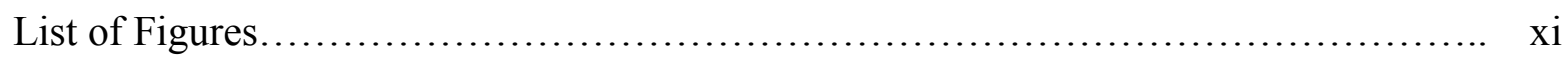

1. Introduction......................................................... 1

1.1. Literature Cited ................................................. 4

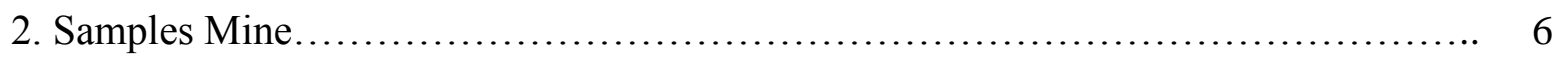

2.1. Literature Review and Objectives............................... 6

2.2. Methods ........................................................ 8

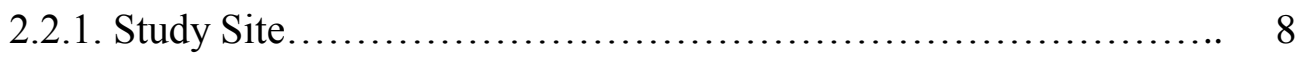

2.2.2. Trees................................................... 11

2.2.3. Soil................................................... 12

2.2.4. Ground Cover........................................... 13

2.2.5. Statistical Analysis...................................... 13

2.3. Results and Discussion........................................ 13

2.3.1. Trees.................................................... 13

2.3.2. Soil............................................... 24

2.3.3. Ground Cover............................................. 27

2.4. Gray Sandstone Study.......................................... 28

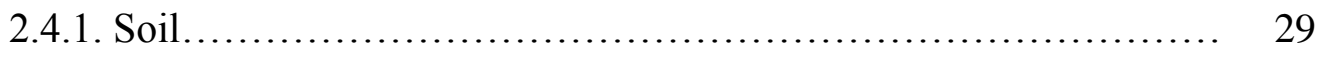

2.4.2. Ground Cover.......................................... 31

2.4.3. Trees.............................................. 32 
2.5. Conclusions ........................................................... $\quad 35$

2.6. Literature Cited......................................................... 37

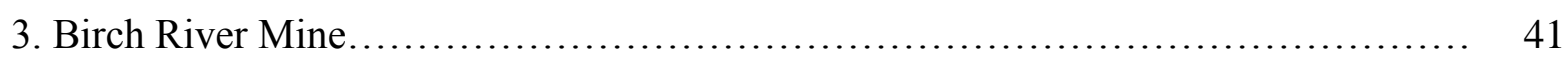

3.1. Literature Review and Objectives...................................... 41

3.2. Methods.............................................................. 43

3.2.1. Study Site ................................................... 43

3.2.2. Trees...................................................... 46

3.2.3. Soil........................................................ 47

3.2.4. Ground Cover.......................................... 47

3.2.5. Statistical Analysis....................................... 48

3.3. Results and Discussion........................................... 48

3.3.1. Trees................................................... 48

3.3.2. Soil........................................................ 60

3.3.3. Ground Cover........................................... 64

3.4. Conclusions.............................................................. 65

3.5. Literature Cited .................................................... 66

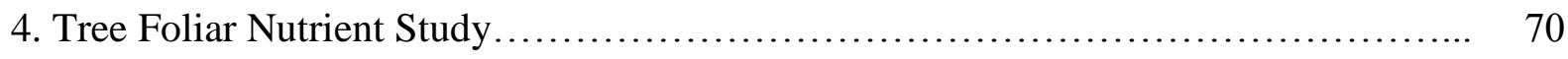

4.1. Literature Review and Objectives.................................... 70

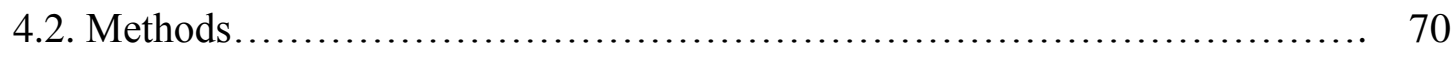

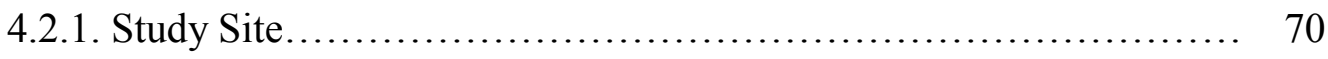

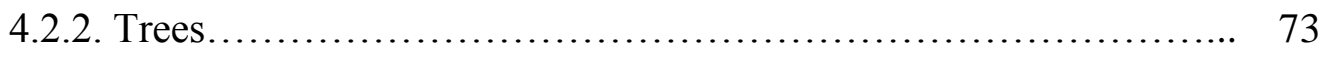

4.2.3. Foliar Nutrient Testing...................................... 73

4.2.4. Soil..................................................... 73

4.2.5. Statistical Analysis........................................... 74

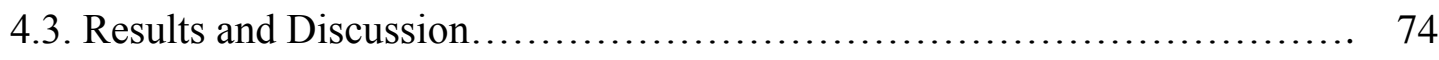


4.3.1. Black Cherry.

4.3.2. Red Oak............................................. 77

4.3.3. Tulip-poplar.......................................... 80

4.4. Conclusions ...................................................... 82

4.5. Literature Cited ..................................................... 84 


\section{List of Tables}

Table

Page No.

Table 2-1. Soil treatment combinations at Catenary Coal's Samples mine in Boone County, WV....

Table 2-2. Species and number of trees planted in 2005 at Catenary Coal's Samples Mine in Boone County, West Virginia..............................

Table 2-3. Species and rates of ground cover hydroseeded in 2007 at Catenary Coal's Samples Mine in Boone County, West Virginia.

Table 2-4. Treatment effects for volume and survival after eight growing seasons in six soil treatments at Catenary Coal's Samples mine in Boone County, WV.

Table 2-5. Mean tree height for 2005, 2009, and 2012 growing seasons in six soil treatments at Catenary Coal's Samples mine in Boone County, WV. 2005 and 2009 data are from Emerson et al. (2009) and DeLong (2010).

Table 2-6. Mean tree volume index ${ }^{¥}$ of tree species in 2012 after eight growing seasons in six soil treatments at Catenary Coal's Samples mine in Boone County, WV.

Table 2-7. Distribution of tree species in 2012 after eight growing seasons in six soil treatments at Catenary Coal's Samples mine in Boone County, WV ...........

Table 2-8. Soil properties of samples from six soil treatments at Catenary Coal's Samples mine in Boone County, WV. 2005 soil data are from Emerson et al.

(2009)

Table 2-9. Soil properties of samples from six treatments at Catenary Coal's Samples mine in Boone County, WV. 2005 soil data are from Emerson et al. (2009)

Table 2-10. Mean ground cover on six soil treatments in 2012 at Catenary Coal's Samples mine in Boone County, WV.

Table 2-11. ANOVA results for selected soil chemical and physical properties, tree volume index, and tree height on the gray sandstone demonstration plot at Catenary Coal's Samples mine, Boone County, West Virginia.

Table 2-12. Unweathered gray sandstone plots at Catenary Coal's Samples mine in Boone County, West Virginia.

Table 2-13. Soil properties of samples from three gray sandstone plots at Catenary Coal's Samples mine in Boone County, WV. 
Table 2-14. Soil properties from three gray sandstone plots at Catenary Coal's

Samples mine in Boone County, WV .....................................

Table 2-15. Mean ground cover on three gray sandstone plots in 2012 at Catenary Coal's Samples mine in Boone County, WV ..................................

Table 2-16. ANOVA results for mean tree volume and mean height on three gray sandstone plots at Catenary Coal's Samples mine in Boone County, WV

Table 2-17. Mean tree volume index ${ }^{¥}$ and height on three gray sandstone plots at Catenary Coal's Samples mine in Boone County, WV ............................

Table 2-18. Distribution of tree species on three gray sandstone plots in 2012 at Catenary Coal's Samples mine in Boone County, WV.

Table 2-19. Mean tree volume index $¥$ of tree species in 2012 on three gray sandstone plots at Catenary Coal's Samples mine in Boone County, WV

Table 3-1. Species and number of trees planted in 2007 at the Arch- Birch River mine in Webster County, West Virginia

Table 3-2. Species and rate of application of ground cover hydroseeded in 2007 at Arch- Birch River mine in Webster County, West Virginia.

Table 3-3. Soil treatment combinations at Arch Coal's Birch River mine in Webster County, WV.

Table 3-4. Treatment effects for volume and survival after six growing seasons in eight soil treatments at Arch Coal's Birch River mine in Webster County, WV......

Table 3-5. Mean tree volume index ${ }^{¥}$ for 2008-2012 growing seasons in eight soil treatments at Arch Coal's Birch River mine in Webster County, WV. 2008 to 2011 data are from DeLong (2010) and Thomas (2012).

Table 3-6. Mean tree volume index ${ }^{¥}$ of each tree species in 2012 after six growing seasons in eight soil treatments at Arch Coal's Birch River mine in Webster County, WV.

Table 3-7. Distribution of tree species in 2012 after six growing seasons in eight soil treatments at Arch Coal's Birch River mine in Webster County, WV...

Table 3-8. 2008-2012 soil properties of samples from eight soil treatments at Arch Coal's Birch River mine in Webster County, WV. 2008 and 2009 data are from DeLong (2010). 2010 and 2011 data are from Thomas (2012)..................

Table 3-9. 2008 and 2012 soil properties of samples from eight treatments at Arch 
Coal's Birch River mine in Webster County, WV. 2008 data are from DeLong (2010).

Table 3-10. Mean ground cover on eight soil treatments in 2012 at Arch Coal's Birch River mine in Webster County, WV

Table 4-1. Soil type descriptions at Arch Coal's Birch River mine in Webster

Table 4-2. Mean foliar nutrient concentrations of black cherry in five soil types....

Table 4-3. Soil chemical properties of five soil types surrounding black cherry at Arch Coal's Birch River mine in Webster County, WV....

Table 4-4. Range of values for foliar nutrient concentrations of black cherry in five

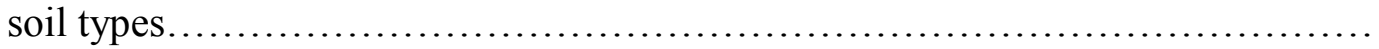

Table 4-5. Mean foliar nutrient concentrations of red oak in five soil types........

Table 4-6. Soil chemical properties of five soil types surrounding red oak at Arch Coal's Birch River mine in Webster County, WV....

Table 4-7. Range of values for foliar nutrient concentrations of red oak in five soil types.

Table 4-8. Mean foliar nutrient concentrations of tulip-poplar in five soil types...

Table 4-9. Range of values for foliar nutrient concentrations of tulip-poplar in five soil types.

Table 4-10. Soil chemical properties of five soil types surrounding tulip-poplar at Arch Coal's Birch River mine in Webster County, WV ............................ 


\section{List of Figures}

Figure 2-1. Location of the compacted new gray plot (GCP) and the ripped gray plot (RIP) in relation to the demonstration plots (outlined in black) at Catenary Coal's Samples mine in Boone County, WV (Google Maps, 2012).......................

Figure 2-2. Average mean volume index 1 with error bars at 5\% after eight growing seasons for six treatments at Catenary Coal's Samples mine in Boone County, WV...

Figure 2-3. Average tree height after eight growing seasons for six treatments at Catenary Coal's Samples mine in Boone County, WV. Means for volume within year with the same letter are not significantly different at $p<0.05 \ldots \ldots \ldots \ldots \ldots \ldots \ldots \ldots$

Figure 2-4. Boxplot of black locust volume index 1 for six treatments at Catenary Coal's Samples mine in Boone County, WV. Black lines within boxes indicate the mean volume index, boxes indicate the upper and lower quartile, and bars outside the box give $99 \%$ of all values (three standard deviations) and circles represent outliers...

Figure 2-5. Boxplot of white oak volume index 1 for six treatments at Catenary Coal's Samples mine in Boone County, WV. Black lines within boxes indicate the mean volume index, boxes indicate the upper and lower quartile, and bars outside the box give $99 \%$ of all values (three standard deviations) and circles represent outliers...

Figure 2-6. Boxplot of white ash volume index 1 on six treatments at Catenary Coal's Samples mine in Boone County, WV. Black lines within boxes indicate the mean volume index, boxes indicate the upper and lower quartile, and bars outside the box give $99 \%$ of all values (three standard deviations) and circles represent outliers...

Figure 2-7. Boxplot of sugar maple volume index 1 for five treatments at Catenary Coal's Samples mine in Boone County, WV. Black lines within boxes indicate the mean volume index, boxes indicate the upper and lower quartile, and bars outside the box give $99 \%$ of all values (three standard deviations) and circles represent outliers...

Figure 2-8. Boxplot of soil $\mathrm{pH}$ in samples from three gray sandstone treatments at Catenary Coal's Samples mine in Boone County, WV. Black lines within boxes indicate the mean volume index, boxes indicate the upper and lower quartile, and bars outside the box give $99 \%$ of all values (three standard deviations).

Figure 2-9. Boxplot of tree heights measured on three gray sandstone treatments in 2012 at Catenary Coal's Samples mine in Boone County, WV. Black lines within boxes indicate the mean volume index, boxes indicate the upper and lower quartile, and bars outside the box give $99 \%$ of all values (three standard deviations) and circles represent outliers

Figure 3-1. Eight treatments were established at the Arch - Birch River mine in 
Webster County, West Virginia. Eleven ("A" to "K") transects were placed to cross the various treatments, and trees and soils were measured within transects.

Figure 3-2. Boxplot of tree volume index on mulched and non-mulched treatments at Arch Coal's Birch River mine in Webster County, WV. Black lines within boxes indicate the mean volume index, boxes indicate the upper and lower quartile, and bars outside the box give $99 \%$ of all values (three standard deviations) and circles represent outliers

Figure 3-3. Mean tree volume index 1 with error bars at 5\% after six growing seasons for eight treatments at Arch Coal's Birch River mine in Webster County, WV

Figure 3-4. Mean tree volume index 1 with error bars at 5\% for black cherry in 2012 on eight treatments at Arch Coal's Birch River mine in Webster County, WV.

Figure 3-5. Mean tree volume index 1 with error bars at 5\% for black locust in 2012 on eight treatments at Arch Coal's Birch River mine in Webster County, WV.........

Figure 3-6. Mean tree volume index 1 with error bars at 5\% for tulip-poplar in 2012 on seven treatments at Arch Coal's Birch River mine in Webster County, WV. No specimens were sampled on the BMH treatment.

Figure 3-7. Mean tree volume index 1 with error bars at 5\% for redbud in 2012 on three treatments at Arch Coal's Birch River mine in Webster County, WV. No specimens were sampled on the $\mathrm{BMH}, \mathrm{BH}, \mathrm{G}, \mathrm{GMH}$, and $\mathrm{GH}$ treatments.

Figure 3-8. Mean tree volume index 1 with error bars at 5\% for sugar maple in 2012 on seven treatments at Arch Coal's Birch River mine in Webster County, WV. No specimens were sampled on the GMH treatment.................................

Figure 4-1. Aerial view of Arch Coal's Birch River mine with close-up views of the experimental plot and the un-mined forested area in Webster County, WV (Google

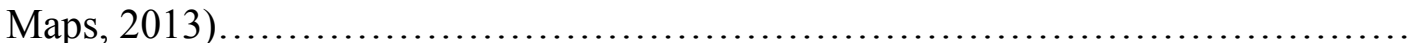




\section{Introduction and Objectives}

Surface coal mining in Appalachia drastically disturbs the surface of the land with the removal of valuable and ecologically diverse eastern deciduous forests (Emerson et al., 2009). The U.S. Office of Surface Mining reports that over 600,000 ha of land have been disturbed in the eastern United States since the enactment of the Surface Mining Control and Reclamation Act in 1977 (USDI OSM, 2008). West Virginia is one of the top coal producing states in the U.S. second only to Wyoming. Overall, West Virginia produced 139,424,080 tons of coal in 2012 from both underground and surface mining operations. Currently, there are 232 active surface mines in West Virginia in 24 counties which produced 48,060,579 tons of coal in 2012 (West Virginia Coal Association, 2012).

In 1977, the Surface Mining Control and Reclamation Act (SMCRA) was developed and enacted because of growing concerns about environmental and safety issues with surface mining. SMCRA mandates standards for coal operators to meet before, during, and after mining operations including restoring the land to its approximate original contour (AOC), minimizing disturbances to the hydrologic system, reclaiming the land in a timely manner, and establishing a permanent vegetative cover (Public Law 95-87, 1977). Many coal operators find that planting a variety of grasses and legumes is the fastest and most economical way to re-establish a permanent vegetative cover. This practice not only benefits the coal operator but it can also provide an economical return to the land owner in the form of hay production or grazing of livestock when properly managed (Emerson et al., 2009). While the establishment of forage crops is quick and economical, often the land is not utilized for hay production or pasture and is not conducive to tree growth when dense, aggressive species such as Kentucky-31 tall fescue (Festuca arundinacea Schreb) and red clover (Trifolium pretense L.) are seeded (Burger, 1999; Emerson et al., 2009). Competition with herbaceous vegetation and compacted soil due to backfilling with heavy equipment create unsuitable conditions for re-establishing forestland on mined surfaces or natural re-colonization of trees on the site (Rodrigue and Burger, 2004). However, if the land is not maintained as hayland or pasture, eventually the natural processes of ecological succession will take over. Decades after mining has ceased, pioneer tree species such as big-toothed aspen (Populus grandidentata Michx.), black birch (Betula lenta L.), black locust (Robinia psuedoacacia L.), Devil's walkingstick (Aralia spinosa L.), pin cherry (Prunus 
pensylvanica L. f.), and red maple (Acer rubrum L.) will colonize the disturbed area and gradually give way to climax species such as northern red oak (Quercus rubra L.), black oak (Quercus velutina L.), sugar maple (Acer saccharum Marsh.), and American basswood (Tilia americana L.) (Johnson and Skousen, 1995). Skousen et al. (1994) reported that mine soils on Abandoned Mine Land (AML) in West Virginia with low $\mathrm{pH}$ were colonized by acid-tolerant grasses and tree species from the surrounding forest.

Recently, regulatory agencies and reclamation scientists have encouraged operators to reestablish hardwood trees on reclaimed surface mines. The Appalachian Regional Reforestation Initiative was started by the Office of Surface Mining, with cooperation from several state agencies and university researchers, and encourages operators to plant more hardwood trees on active and abandoned coal mined lands. The practice of planting hardwood trees and to restore a forest will enhance wildlife habitat, promote soil and water conservation, increase timber value, and provide an economically valuable post mining land use for the landowner (Burger, 2009; Larkin et al., 2008). A recent study found that restoring previously forested mined land to a level of productivity which is equal to or greater than its pre-mining production has great potential to sequester atmospheric $\mathrm{CO}_{2}$ (Amichev et al., 2008). The ARRI Statement of Mutual Intent recommends using Forestry Reclamation Approach (FRA) technology. The five FRA steps are (Burger et al., 2005):

1.) create a suitable rooting medium for tree growth;

2.) loosely grade the topsoil or topsoil substitute;

3.) seed a tree compatible ground cover;

4.) plant early successional tree species and commercially valuable crop trees; and

5.) use proper tree planting techniques.

These techniques have been shown to increase survival and growth rates of trees, increase overall productivity, and promote natural colonization and succession of native plants and wildlife communities (ARRI, 2012; Zipper et al., 2011). 
The objectives of this study were to:

1. Determine tree growth and survival on mined land using two different overburden types as growth media (brown sandstone and gray sandstone) and compacted at two levels at the Samples mine in Boone County, West Virginia.

2. Determine the establishment of herbaceous vegetation cover on the above treatments.

3. Determine tree growth and survival on amended and non-amended (bark mulch vs. no bark mulch and hydroseed vs. no hydroseed) brown and gray sandstone mine soils at the Birch River mine in Webster County, West Virginia.

4. Determine changes in soil chemical properties in treatments at both mine sites.

5. Determine the effect of overburden type (brown sandstone vs. gray sandstone) and amendment (bark mulch vs. no bark mulch) on soil nutrient concentrations and foliar nutrient concentrations in three deciduous hardwood tree species at the Birch River mine in Webster County, West Virginia. 


\subsection{Literature Cited}

Amichev, B.Y., J.A. Burger, J.A. Rodrigue. 2008. Carbon sequestration by forests and soils on mined land in the Midwestern and Appalachian coalfields of the U.S. Forest Ecology and Management 256: 1949-1959.

ARRI. 2012. "Statement of Mutual Intent." Available at http://arri.osmre.gov/SMI/SMI.shtm

Burger, J.A. 1999. Academic research perspective on experiences, trends, constraints and needs related to reforestation of mined land. p. 63-74. In: Proceedings, Enhancement of Reforestation at Surface Coal Mines: Technical Interactive Forum, March 23-24, 1999. Fort Mitchell, KY.

Burger, J.A., D. Graves, P. Angel, V. Davis, C. Zipper. 2005. The Forestry Reclamation Approach. Forest Reclamation Advisory No. 2. p. 1-4. Available at http://arri.osmre.gov/Publications/Publications.shtm. Accessed 1 December 2012.

Burger, J.A. 2009. Restoring the value of forests on reclaimed mined land. Virginia Cooperative Extension Publication 460-138. Available at http://pubs.ext.vt.edu/460/460138/460-138.html Accessed 1 December 2012.

Emerson, P., J. Skousen, and P. Ziemkiewicz. 2009. Survival and growth of hardwoods in brown versus gray sandstone on a surface mine in West Virginia. J. Environ. Qual. 38:18211829

Johnson, C.D., and J.G. Skousen. 1995. Minesoil properties of 15 abandoned mine land sites in West Virginia. J. Environ. Qual. 24: 635-643.

Larkin, J.L., D. Maehr, J. Krupa, J. Cox, K. Alexy, D. Unger, and C. Barton. 2008. Small mammal response to vegetation and spoil conditions on a reclaimed surface mine in Eastern Kentucky. Southeastern Naturalist 7: 401-412.

Public Law 95-87. 1977. Office of Surface Mining. Available at www.osmre.gov/topic/smcra/smcra.shtm Accessed 1 December 2012.

Rodrigue, J.A. and J.A. Burger. 2004. Forest soil productivity of mined land in the Midwestern and Eastern coalfield regions. Soil Sci. Soc. Am. J. 68: 833-844.

Skousen, J.G., C.D. Johnson, and K. Garbutt. 1994. Natural revegetation of 15 abandoned mine land sites in West Virginia. J. Environ. Qual. 23: 1224-1230.

USDI Office of Surface Mining (OSM). 2008. Annual Evaluation Reports for States and Tribes. US Dept. of the Interior, Washington, DC. Available at 
http://www.osmre.gov/reports/annualreport/AnnualReport.shtm. Accessed 1 December 2012.

West Virginia Coal Association. 2012. Coal Facts. Available at http://www.wvcoal.com/docs/Coal\%20Facts\%202012.pdf. Accessed 1 April 2013.

Zipper, C.E., J.A. Burger, J.G. Skousen, P.N. Angel, C.D. Barton, V. Davis, J.A. Franklin. 2011. Restoring forests and associated ecosystem services on Appalachian coal surface mines. Environmental Management 47: 751-765. 
2. Tree Survival and Growth at the Samples Mine

\subsection{Literature Review and Objectives}

The designation of forestry and commercial forestry post-mining land uses in West Virginia requires operators to place 4 or 5 feet $(1.2$ or $1.5 \mathrm{~m})$ of weathered brown sandstone and topsoil on the surface. This performance standard was established in the West Virginia surface mining regulations to optimize the growth of commercially valuable trees and to re-establish a forest ecosystem. In some cases, brown sandstone and topsoil are not available in sufficient quantities to meet this standard. Therefore, coal operators in Appalachia must make use of topsoil substitutes to achieve required depths of soil material. Natural soils are often too shallow to recover or are lost during preliminary mining preparations (timbering and road and drilling construction) to be saved, stockpiled, and redistributed during reclamation to a sufficient depth required by the regulations (Torbert et al., 1990; Emerson et al., 2009). In West Virginia, the predominant overburden rock type is sandstone. When overburden is removed, two types of sandstone are revealed: brown sandstone, which is weathered, contains little pyrite and siderite, and is moderately acidic; and gray sandstone, which is unweathered, potentially contains high levels of pyrite, and is slightly- to moderately-alkaline (Emerson et al., 2009).

Studies have shown that selecting the appropriate material from the overburden to create mine soils is important when forestry is designated as the post mining land use. Finely-textured soils that develop from siltstone and shale contain elevated levels of soluble salts, which can negatively impact the growth and survival of tree seedlings (Torbert et al., 1988; McFee et al., 1981). Torbert et al. (1990) reported that sandstone-derived mine soils produced five times more stem volume than siltstone-derived mine soils. Showalter et al. (2010) reported that weathered sandstone was more conducive to native hardwood tree growth than unweathered sandstone or unweathered shale. It was concluded that the lower $\mathrm{pH}$ and higher water retention of the weathered sandstone were the major contributors to better growth. Emerson et al. (2009) found that tree growth and volume were five times higher after three years on brown sandstone than gray sandstone.

The Forestry Reclamation Approach (which is slightly more lenient in the growth media requirement than the West Virginia regulations) recommends using weathered brown sandstone 
mixed with pre-mining forest soil during reclamation to achieve a depth of at least four feet (1.2 m). In the event of inadequate quantities of weathered brown sandstone and forest soil, researchers who developed the FRA recommend mixing unweathered gray sandstone with the available weathered brown sandstone and/or forest soil (Skousen et al., 2011).

When reclaiming lands to a forestry post-mining land use, highly compacted mine soils can make reforestation very difficult (Burger, 1999). Soil compaction can result in root restriction, reductions in soil nutrient and water movement, increased resistance to root penetration, and poor aeration (Brady and Weil, 2002). Some studies have reported bulk densities on reclaimed mine soils to be as high as $1.84 \mathrm{Mg} \mathrm{m}^{-3}$ (DeLong et al., 2012). Many hardwood tree species experience root growth limitations at bulk densities of $1.4 \mathrm{Mg} \mathrm{m}^{-3}$ for clayey soils and $1.55 \mathrm{Mg} \mathrm{m}^{-3}$ for loamy soils (Coder, 1998). Tyner et al. (1948) reported that compacted surface layers down to $45 \mathrm{~cm}$ created survival problems for tree seedlings and some grasses during dry periods. Conlin (1996) found that root growth in both Douglas-fir (Pseudotsuga menziesii (Mirb.) Franco) and lodgepole pine (Pinus contorta Douglas ex Loudon) decreased in response to increasing levels of compaction. Another study found that seedling growth of red oak (Quercus rubra L.) and scarlet oak (Quercus coccinea Muench.) was severely hindered by soil compaction (Jordon et al., 2003). In particular, they reported a decrease in seedling height and total dry matter (roots, stems, and leaves). Minimizing soil compaction on surface mines through decreased grading improved the survival and height of tulip-poplar (Liriodendron tulipifera L.), northern red oak (Quercus rubra L.), white oak (Quercus alba L.), and eastern white pine (Pinus strobus L.) (Angel et al., 2006).

In an effort to ameliorate the effects of compaction, one study ripped a compacted mine soil and found that ripping significantly improved tree growth on a reclaimed surface mine in Kentucky (Burger and Evans, 2010). Ashby (1996) reported that percent survival, height, and diameter at breast height (DBH) of red oak (Quercus rubra L.) and black walnut (Juglans nigra L.) were significantly greater on ripped mine soils in Illinois compared to non-ripped mine soils. A similar study also reported higher percent survival and tree height for native hardwood tree species on ripped mine soils (Ashby, 1997). Skousen et al. (2009) found that ripping reclaimed grasslands to $1 \mathrm{~m}$ in depth improved survival and growth of black cherry (Prunus serotina Ehrh.), red oak, tulip-poplar, white oak, and black walnut. However, due to the detrimental 
effects of soil compaction, the Forestry Reclamation Approach recommends lightly grading the soil surface when forestry is the assigned post-mining land use.

The objective of this study was to determine tree growth and survival on weathered brown sandstone and unweathered gray sandstone with and without compaction. Herbaceous ground cover and soil chemical properties were also determined on all treatments.

\subsection{Methods}

\subsubsection{Study Site}

The Samples Mine is located approximately $50 \mathrm{~km}$ south of Charleston, WV and is owned by Patriot Coal and operated by the Catenary Coal Company. The mine crosses the boundaries of Kanawha, Raleigh, and Boone Counties with the study area being located in Boone County.

In January 2005, Catenary Coal Company constructed three 2.8-ha demonstration plots at the Samples Mine in Boone County, West Virginia (38 05'28" N 081 26'37" W), to evaluate the growth and survival of commercially valuable hardwood trees on unweathered gray sandstone and weathered brown sandstone. The first plot was composed of $1.5 \mathrm{~m}$ of weathered brown sandstone placed on the surface, the second plot was composed of $1.2 \mathrm{~m}$ of weathered brown sandstone placed on the surface, and the third plot was composed of $1.5 \mathrm{~m}$ of unweathered gray sandstone placed on the surface.

One half of each plot was compacted with several passes of a bulldozer and the other half was not compacted with only one or two passes of a bulldozer (Figure 2-1). Overall, six treatments were created (Table 2-1). In March 2005, eleven species of 2-year-old tree seedlings were professionally planted on 2.3 by $2.3-\mathrm{m}$ centers (Table 2-2). In the fall of 2007, the plots were hydroseeded with a mixture of tree compatible vegetation (Table 2-3) at a rate of $15.4 \mathrm{~kg}$ ha $^{-1}$. 
Table 2-1. Soil treatment combinations at Catenary Coal's Samples mine in Boone County, WV.

\begin{tabular}{lc}
\hline Treatment & Abbreviation \\
\hline $1.2-\mathrm{m}$ weathered brown sandstone compacted & $1.2 \mathrm{BC}$ \\
$1.2-\mathrm{m}$ weathered brown sandstone non-compacted & $1.2 \mathrm{BNC}$ \\
$1.5-\mathrm{m}$ weathered brown sandstone compacted & $1.5 \mathrm{BC}$ \\
$1.5-\mathrm{m}$ weathered brown sandstone non-compacted & $1.5 \mathrm{BNC}$ \\
$1.5-\mathrm{m}$ unweathered gray sandstone compacted & $\mathrm{GC}$ \\
$1.5-\mathrm{m}$ unweathered gray sandstone non-compacted & $\mathrm{GNC}$ \\
\hline
\end{tabular}

Table 2-2. Species and number of trees planted in 2005 at Catenary Coal's Samples Mine in Boone County, West Virginia.

\begin{tabular}{lcc}
\hline Species & Number of trees planted & Percent of trees planted \\
\hline Red oak (Quercus rubra L.) & 3400 & 22 \\
White oak (Quercus alba L.) & 2500 & 16 \\
White ash (Fraxinus americana L.) & 2500 & 16 \\
Sugar maple (Acer saccharum Marsh.) & 1500 & 10 \\
Chestnut oak (Quercus prinus L.) & 1250 & 8 \\
Tulip-poplar (Liriodendron tulipifera & 1250 & 8 \\
L.) & 1250 & 8 \\
White pine (Pinus strobus L.) & 465 & 3 \\
Black cherry (Prunus serotina Ehrh.) & 465 & 3 \\
Dogwood (Cornus alternifolia L.) & 465 & 3 \\
Eastern Redbud (Cercis canadensis L.) & 465 & 3 \\
Blacklocust (Robinia pseudoacacia L.) & & \\
& 15,510 & 100 \\
\hline
\end{tabular}


Table 2-3. Species and rates of ground cover hydroseeded in 2007 at Catenary Coal's Samples Mine in Boone County, West Virginia.

\begin{tabular}{lc}
\hline Species & Rate \\
\hline & $\mathrm{kg} \mathrm{ha}^{-1}$ \\
\hline Redtop (Agrostis gigantea Roth) & 2.2 \\
Perennial ryegrass (Lolium perenne L.) & 2.2 \\
Birdsfoot trefoil (Lotus corniculatus L.) & 11.0 \\
& \\
Total & 15.4 \\
\hline
\end{tabular}

As a comparison to tree performance on the unweathered gray sandstone demonstration plot, which appeared to have exceptionally poor tree growth during our initial studies, two other gray sandstone areas adjacent to the demonstration plots and reclaimed similarly in 2005 were measured for chemical properties and mean tree volume index in 2012. One site was compacted (GCP) while the other site was compacted and then ripped (RIP); each plot is 2.8-ha (Figure 2$1)$. 


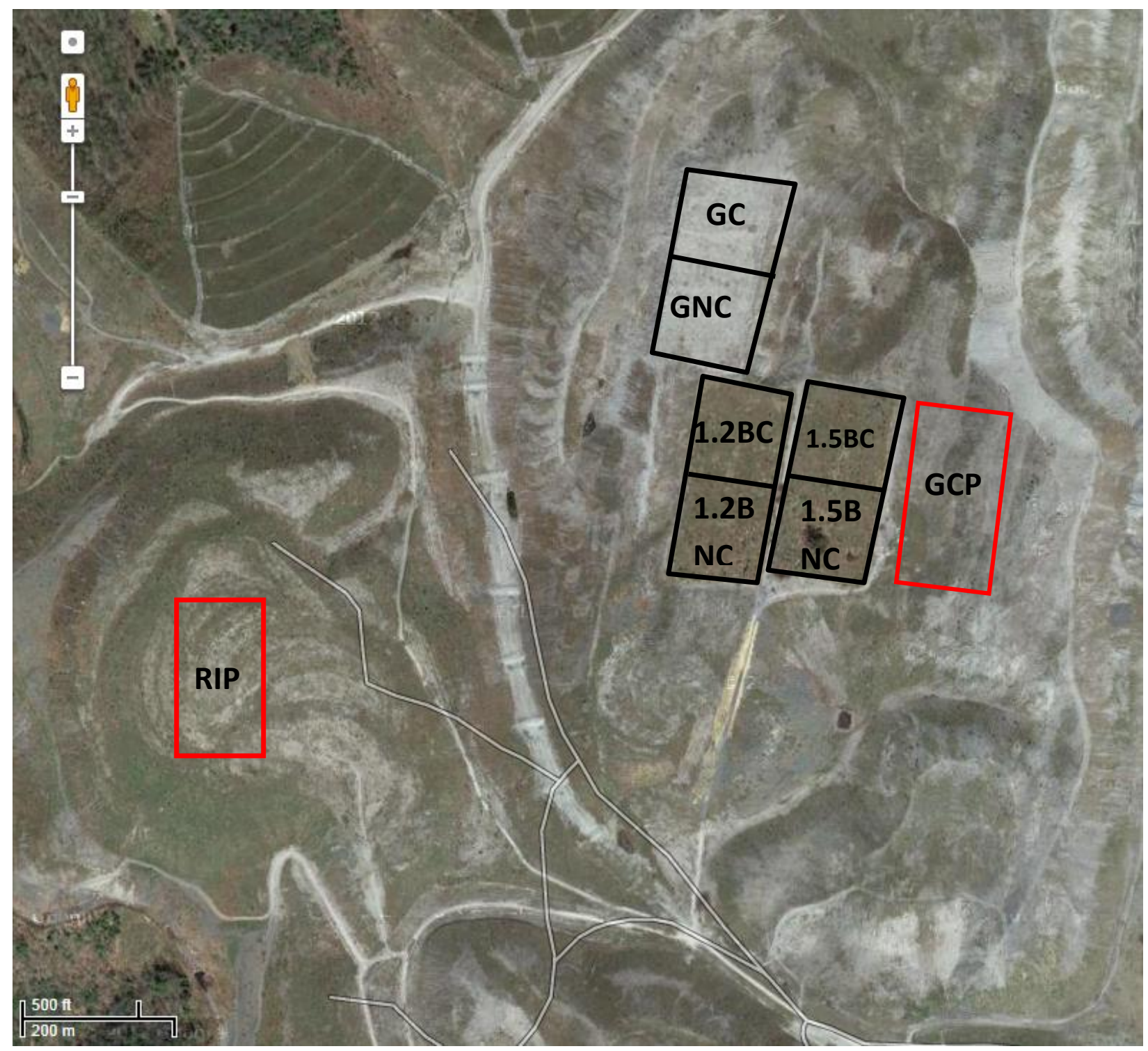

Figure 2-1. Location of the compacted new gray plot (GCP) and the ripped gray plot (RIP) in relation to the demonstration plots (outlined in black) at Catenary Coal's Samples mine in Boone County, WV (Google Maps, 2012).

\subsubsection{Trees}

Two, 2.7-m wide by 195-m long transects were established in an " $\mathrm{X}$ " pattern across each of the 2.8-ha plots. Any tree within the 2.7-m wide transect was identified by species, and measured for height and diameter. Tree height was measured to highest live growth and tree stem diameter was measured approximately $2.5 \mathrm{~cm}$ above the soil surface. Tree growth was assessed using the formula: 
Tree volume index $\left(\mathrm{cm}^{3}\right)=$ Height $(\mathrm{cm}) \times$ Stem diameter ${ }^{2}\left(\mathrm{~cm}^{2}\right) \quad$ (Emerson et al., 2009)

Tree survival for the demonstration plots was calculated by finding the difference between the number of trees measured in 2005 and the number of trees measured in 2012. Tree survival was not determined on the two new gray plots because no original tree planting data on numbers and species were available. Tree sampling was conducted during late July to early August every year.

Beginning in summer 2012, tree diameter was measured at $10 \mathrm{~cm}$ and $2.5 \mathrm{~cm}$ above the soil surface. Foresters use the standard procedure diameter at breast height (DBH; 1.37-m or 4.5 feet) to measure diameter for mature trees. However, the tree seedlings growing at the experimental site were too small to be measured using DBH. In previous years, tree seedlings at the demonstration plots were measured for diameter at $2.5 \mathrm{~cm}$, but as the trees grew taller diameter should be measured at a higher point on the tree stem until they reach the appropriate height to begin using DBH. For the purpose of this study, all references to volume index will specifically refer to volume index measured at $2.5 \mathrm{~cm}$ (Volume Index 1) although volume indices measured at $10 \mathrm{~cm}$ (Volume Index 2) are included in Table 2-4.

\subsubsection{Soil}

Soil samples were collected in June of each year to a depth of $15 \mathrm{~cm}$ from five randomlyselected points along each transect within each treatment. Soil samples were air dried and sieved to pass through a 2-mm screen. The fine soil fraction was used to determine $\mathrm{pH}$, extractable nutrients, and electrical conductivity. Soil $\mathrm{pH}$ was determined with a 1:1 mixture in DDI water using a Fisher Scientific Accumet pH meter model 915 (Thermo Fisher Scientific Inc. Pittsburgh, PA). Electrical conductivity (EC) was determined using a 1:2 mixture comprised of 5 grams of soil and $10 \mathrm{~mL}$ of DDI water using a Mettler Toledo S230 EC meter (Mettler-Toledo International Inc. Columbus, OH). Nutrient availability was determined using the Mehlich 1 extracting solution $\left(0.025 \mathrm{~N} \mathrm{H}_{2} \mathrm{SO}_{4}+0.05 \mathrm{~N} \mathrm{HCl}\right)$. The extracted solution was analyzed for available potassium, calcium, magnesium, phosphorus, iron, and aluminum using a Perkin Elmer Optima DV 2100 emission spectrophotometer (Perkin-Elmer Corp. Norwalk, CT). 


\subsubsection{Ground Cover}

Percent ground cover was evaluated within a $1-\mathrm{m}^{2}$ quadrat. The quadrat was placed at twenty random locations within each treatment. Percent live herbaceous cover, litter cover, live tree cover, standing water, bare soil, and rocks were estimated to the nearest $5 \%$. Ground cover was evaluated during early August.

\subsubsection{Statistical Analysis}

Tree data were analyzed using one-way ANOVA ( $\mathrm{R}$ language) by sandstone type, compaction, depth, interactions, and species (R Development Core Team, 2012). Tukey's Honest Significant Difference (HSD) test was used to separate means at the level $p<0.05$. Tree volume index data contained unequal variances so volume data were log transformed to equalize the variances. Box plots were used to illustrate the trends for volume indices of selected tree species across treatments.

Soil data were analyzed by one-way ANOVA (R language) by treatment combinations within year for $\mathrm{pH}$, electrical conductivity, extractable nutrients, and percent fines. Tukey's HSD test was used to separate means at the level $\mathrm{p}<0.05$.

Percent ground cover data were analyzed using a one-way ANOVA (R language) to compare cover types (herbaceous, tree, bare soil or rock, water, and total cover) by soil treatment combinations for 2012. Tukey's HSD test was used to separate means at $p<0.05$. All statistical analyses were performed using the statistical program R (R Development Core Team, 2012).

\subsection{Results and Discussion}

\subsubsection{Trees}

Average tree survival was greater on brown sandstone treatments (76\%) than gray sandstone treatments (55\%) (Table 2-4). Average tree survival on compacted treatments was $79 \%$ compared to $62 \%$ on non-compacted treatments. Black locust had the highest survival at $100 \%$ followed by white ash with a survival rate of $66 \%$. Black cherry and sugar maple had the lowest survival rates at 11 and $27 \%$, respectively. 
Previous research studies on this site (Emerson et al., 2009 and DeLong, 2010) showed that tree survival was similar between brown sandstone and gray sandstone treatments. This result was also shown in other studies where gray and brown sandstone gave similar tree survival values during early years after planting (Skousen et al., 2011; Angel et al., 2008). This was the first time during this 8-yr study that survival was greater on brown sandstone vs. gray sandstone. Clearly the non-compacted gray sandstone treatment was the reason for the difference with only $31 \%$ survival, while the compacted gray treatment had $83 \%$ survival, similar to the other brown treatments. One explanation for this result is that the greater percentage of fines on the brown sandstone allowed for the soil to hold more plant-available water and nutrients than the low percentage of fines in the gray sandstone (Miller et al., 2010). Plus, compaction of the gray sandstone treatment may have broken up the rocks more than in the non-compacted gray sandstone treatment resulting in a more fine-textured surface material.

Brown sandstone treatments had significantly higher mean tree volume indices (3853 $\mathrm{cm}^{3}$ ) than gray sandstone treatments $\left(407 \mathrm{~cm}^{3}\right)$ (Table 2-4). Non-compacted treatments had significantly higher tree volume indices with an average tree volume index of $3899 \mathrm{~cm}^{3}$ compared to $2281 \mathrm{~cm}^{3}$ on compacted treatments. Depth of brown sandstone treatment was not statistically significant at $\mathrm{p}<0.05$ (Table 2-4), which indicates at this stage of development the tree roots have sufficient rooting volume in both $1.2-\mathrm{m}$ and $1.5-\mathrm{m}$ depths of soil material.

Table 2-4. Treatment effects for volume and survival after eight growing seasons in six soil treatments at Catenary Coal's Samples mine in Boone County, WV.

\begin{tabular}{|c|c|c|c|c|c|c|}
\hline \multirow{2}{*}{\multicolumn{2}{|c|}{ Substrate }} & Survival & $\begin{array}{l}\text { Volume } \\
\text { Index } 1^{\ddagger}\end{array}$ & SE & $\begin{array}{l}\text { Volume } \\
\text { Index } 2^{\epsilon}\end{array}$ & $\begin{array}{c}\text { Volume } \\
\text { Difference }^{\dagger}\end{array}$ \\
\hline & & $-\%-$ & $-\mathrm{cm}^{3}-$ & & $-\mathrm{cm}^{3}-$ & $-\%-$ \\
\hline & Brown & 76 & $3853^{a} \mathrm{f}$ & 759 & $3161^{\mathrm{a}}$ & 18 \\
\hline & Gray & 55 & $407^{\mathrm{b}}$ & 69 & $291^{\mathrm{b}}$ & 29 \\
\hline
\end{tabular}

Compaction

$\begin{array}{lccccc}\text { Compacted } & 79 & 2281^{\mathrm{a}} & 498 & 1816^{\mathrm{a}} & 20 \\ \begin{array}{l}\text { Non- } \\ \text { compacted }\end{array} & 62 & 3899^{\mathrm{b}} & 1107 & 3239^{\mathrm{b}} & 17\end{array}$

Depth 


$\begin{array}{lrrrrr}1.2 \mathrm{~m} & 73 & 3314 & 969 & 2789^{\mathrm{a}} & 16 \\ 1.5 \mathrm{~m} & 80 & 4354 & 1157 & 3507^{\mathrm{b}} & 19\end{array}$

Interaction

$\begin{array}{lccccc}1.2 \mathrm{BC} \S & 69 & 2550^{\mathrm{a}} & 825 & 2050^{\mathrm{a}} & 20 \\ 1.2 \mathrm{BNC} & 77 & 3913^{\mathrm{a}} & 1605 & 3369^{\mathrm{a}} & 14 \\ 1.5 \mathrm{BC} & 84 & 3556^{\mathrm{a}} & 1104 & 2842^{\mathrm{a}} & 20 \\ 1.5 \mathrm{BNC} & 75 & 5182^{\mathrm{a}} & 2064 & 4196^{\mathrm{a}} & 19 \\ \text { GC } & 83 & 449^{\mathrm{b}} & 93 & 335^{\mathrm{b}} & 25 \\ \text { GNC } & 31 & 309^{\mathrm{b}} & 76 & 211^{\mathrm{b}} & 32\end{array}$

Species

\begin{tabular}{|c|c|c|c|c|c|}
\hline Black cherry & 11 & $1456^{\mathrm{ab}}$ & 525 & $1070^{\mathrm{abc}}$ & 28 \\
\hline Black locust & 100 & $5443^{\mathrm{ab}}$ & 1805 & $4603^{\mathrm{bc}}$ & 28 \\
\hline Dogwood & 44 & $2517^{\mathrm{ab}}$ & 1017 & $2202^{\mathrm{abc}}$ & 23 \\
\hline Redbud & 33 & $1390^{\mathrm{a}}$ & 279 & $1132^{\mathrm{a}}$ & 26 \\
\hline Red oak & 60 & $1923^{\mathrm{ab}}$ & 362 & $1470^{\mathrm{ab}}$ & 32 \\
\hline Sugar maple & 27 & $314^{\mathrm{b}}$ & 116 & $218^{\mathrm{c}}$ & 35 \\
\hline Tulip-poplar & 52 & $1238^{\mathrm{ab}}$ & 401 & $915^{\mathrm{abc}}$ & 33 \\
\hline White ash & 66 & $1166^{\mathrm{ab}}$ & 198 & $915^{\mathrm{abc}}$ & 27 \\
\hline White oak & 65 & $3147^{\mathrm{ab}}$ & 644 & $2443^{\mathrm{abc}}$ & 26 \\
\hline White pine & 51 & $2942^{\mathrm{ab}}$ & 1184 & $2403^{\mathrm{abc}}$ & 20 \\
\hline
\end{tabular}

$\S$ see Table 2-1 for treatment descriptions.

${ }^{¥}$ diameter measured at $2.5 \mathrm{~cm}$ above soil surface.

${ }^{€}$ diameter measured at $10 \mathrm{~cm}$ above soil surface.

$\dagger$ percent difference between volume index 1 and volume index 2 .

${ }^{\mathrm{I}}$ means for each treatment within column group with the same letter are not significantly different at $\mathrm{p}<$ 0.05 .

Overall, trees growing on brown sandstone treatments displayed superior performance than those on gray sandstone treatments (Figure 2-2). Average tree volume index across all 
species on brown sandstone was nearly 10 times greater than average tree volume index on gray sandstone. These results were consistent with similar studies (Emerson et al., 2009; Torbert et al., 1990). In a study by Showalter et al. (2010), white ash (Fraxinus americana L.) and northern red oak displayed greater stem and root biomass on weathered sandstone than on unweathered sandstone or unweathered shale. Improved tree performance was attributed to the lower $\mathrm{pH}$ and higher percent fines. Showalter et al. (2010) concluded that weathered sandstone was the best topsoil substitute and more closely mimicked the native forest soil of the Appalachian region.

Compaction had a statistically significant influence on tree volume index. This is the first year since this study began in 2005 where tree volume indices were significantly lower in compacted treatments vs. non-compacted treatments. Soil compaction can limit water and air infiltration, increases resistance to root penetration, and constricts root growth resulting in a shallow root space. Burger and Fannon (2009) reported that trees growing on mined soils reclaimed using traditional grading practices were less productive than tree stands at pre-mining levels. On a surface mine site in eastern Kentucky, Burger and Evans (2010) found that sweetgum (Liquidambar styraciflua L.), tulip-poplar, loblolly pine (Pinus taeda L.), and white pine planted on compacted mine soils grew poorly. 


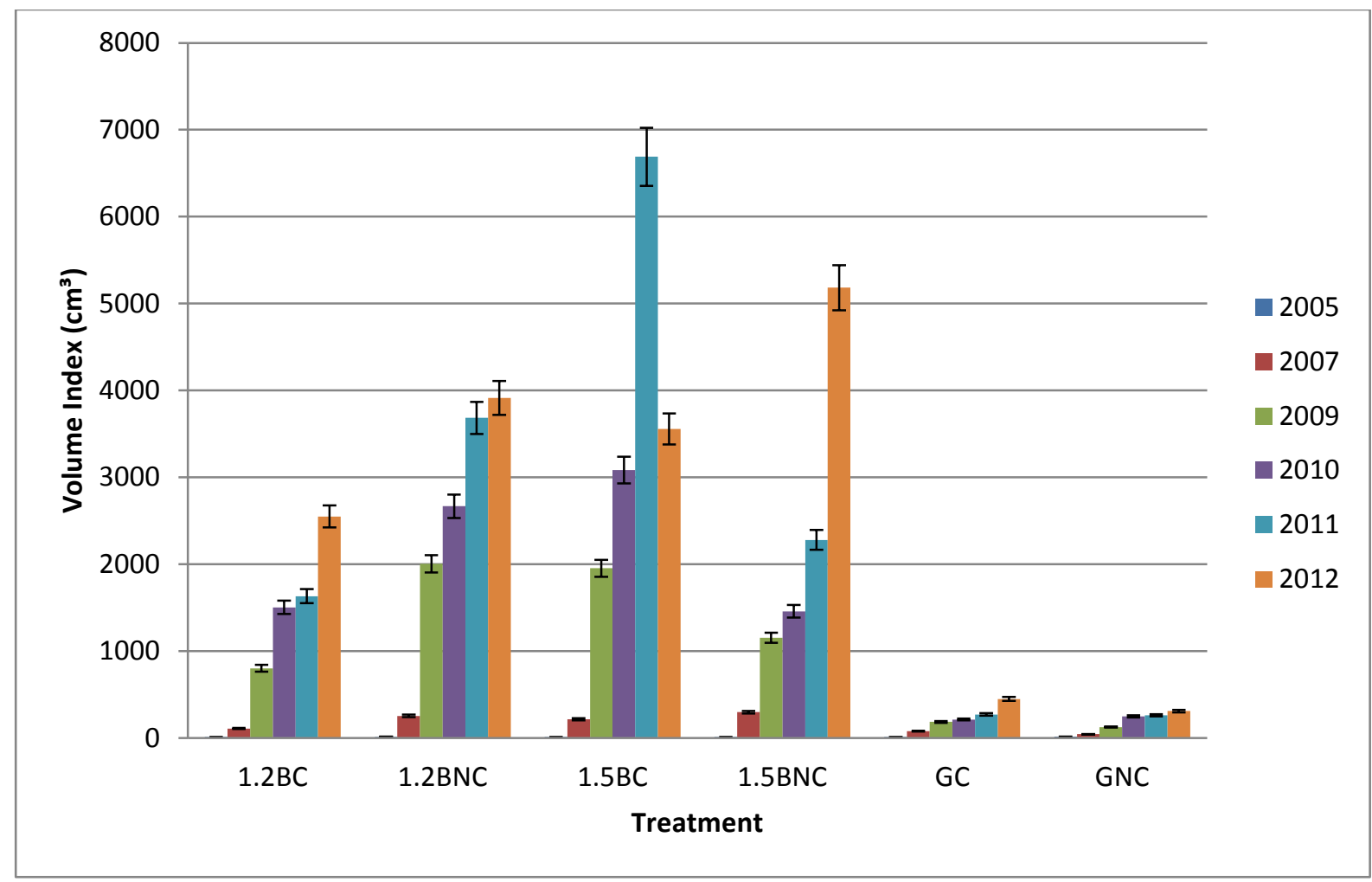

Figure 2-2. Average mean volume index 1 with error bars at $5 \%$ after eight growing seasons for six treatments at Catenary Coal's Samples mine in Boone County, WV.

Average tree height was also significantly higher on brown sandstone than on gray sandstone treatments in 2012 (Figure 2-3). In 2012, brown sandstone treatments had an average height of 131 to $166 \mathrm{~cm}$ compared to a range of 66 to $72 \mathrm{~cm}$ on gray sandstone treatments (Table 2-5). Average tree height has been significantly greater on brown sandstone treatments than on gray sandstone treatments since 2009 (Table 2-5).

Table 2-5. Mean tree height for 2005, 2009, and 2012 growing seasons in six soil treatments at Catenary Coal's Samples mine in Boone County, WV. 2005 and 2009 data are from Emerson et al. (2009) and DeLong (2010).

\begin{tabular}{|c|c|c|c|c|c|c|}
\hline \multirow[b]{2}{*}{ Year } & \multicolumn{6}{|c|}{ Treatments $\S$} \\
\hline & $1.2 \mathrm{BC}$ & 1.2BNC & $1.5 \mathrm{BC}$ & 1.5BNC & GC & GNC \\
\hline 2005 & $37^{\mathrm{a} i}$ & $40^{\mathrm{a}}$ & $37^{\mathrm{a}}$ & $40^{\mathrm{a}}$ & $38^{\mathrm{a}}$ & $40^{\mathrm{a}}$ \\
\hline 2009 & $99^{\mathrm{ab}}$ & $131^{\mathrm{a}}$ & $108^{\mathrm{ab}}$ & $86^{\mathrm{b}}$ & $56^{\mathrm{c}}$ & $43^{c}$ \\
\hline 2012 & $131^{\mathrm{a}}$ & $157^{\mathrm{a}}$ & $142^{\mathrm{a}}$ & $166^{\mathrm{a}}$ & $72^{b}$ & $66^{\mathrm{b}}$ \\
\hline
\end{tabular}

$\S$ see Table 2-1 for treatment descriptions

${ }^{\mathrm{t}}$ means for height within rows with the same letter are not significantly different at $\mathrm{p}<0.05$ 


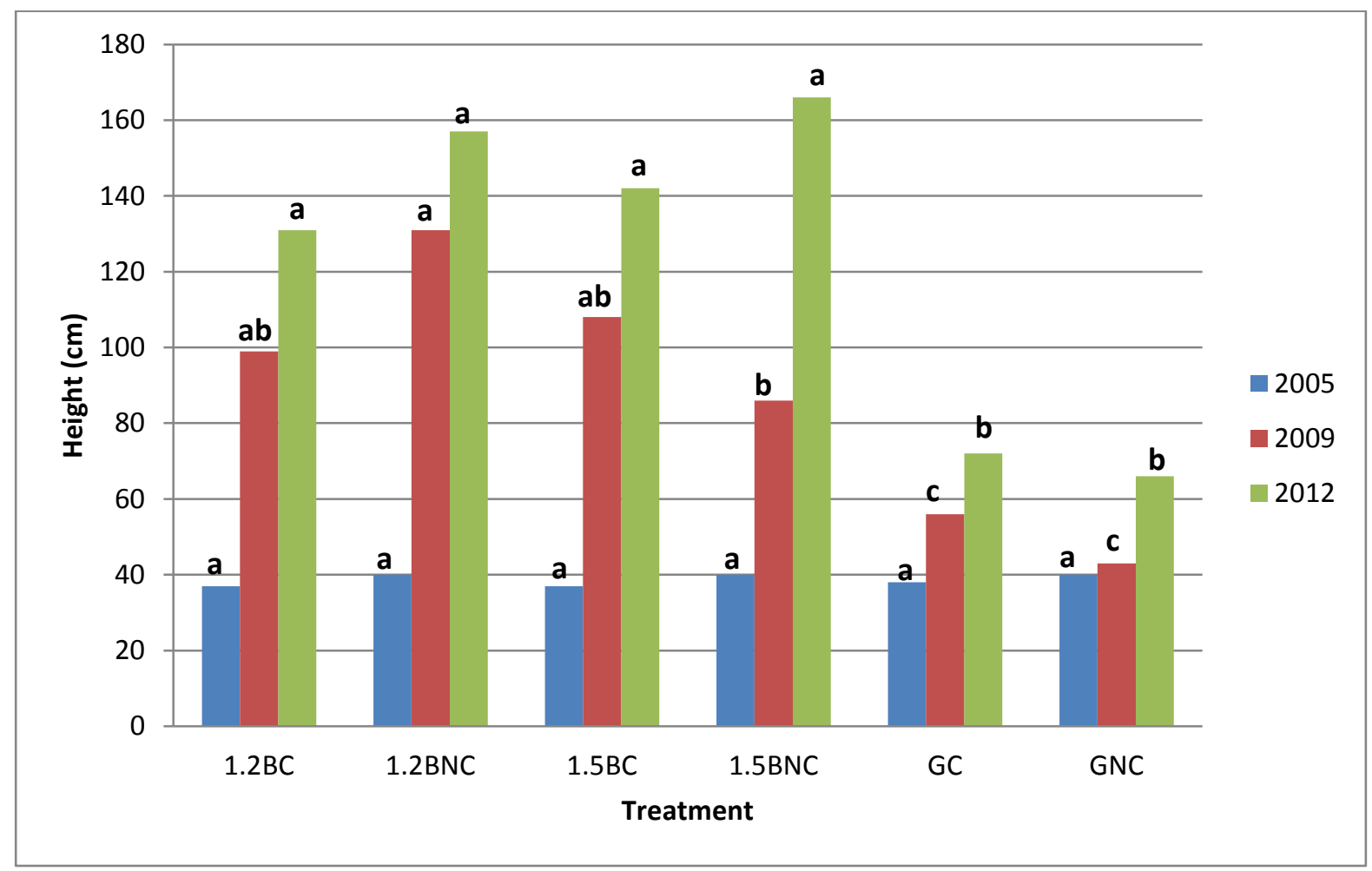

Figure 2-3. Average tree height after eight growing seasons for six treatments at Catenary Coal's Samples mine in Boone County, WV. Means for height within year (same column color) with the same letter are not significantly different at $p<0.05$.

Black locust had the highest average tree volume index at $5443 \mathrm{~cm}^{3}$ and white oak was second with $3147 \mathrm{~cm}^{3}$ (Table 2-4). Sugar maple displayed the lowest growth with an average volume index of $314 \mathrm{~cm}^{3}$. Redbud behaved similarly to sugar maple with a mean volume index of $1390 \mathrm{~cm}^{3}$ and a survival rate of only $33 \%$. In this study, black locust had the widest range of values for tree volume index (Figure 2-4).

In general, tulip-poplar displayed a mean volume index, $1238 \mathrm{~cm}^{3}$, which was statistically similar to white ash, $1166 \mathrm{~cm}^{3}$. Dogwood and white pine also behaved similarly with mean volume indices of $2517 \mathrm{~cm}^{3}$ and $2942 \mathrm{~cm}^{3}$, respectively. Overall, red oak had a similar survival rate, $60 \%$, as white oak, $65 \%$, but had a lower mean volume index of $1923 \mathrm{~cm}^{3}$ although it was not significantly different from white oak. 


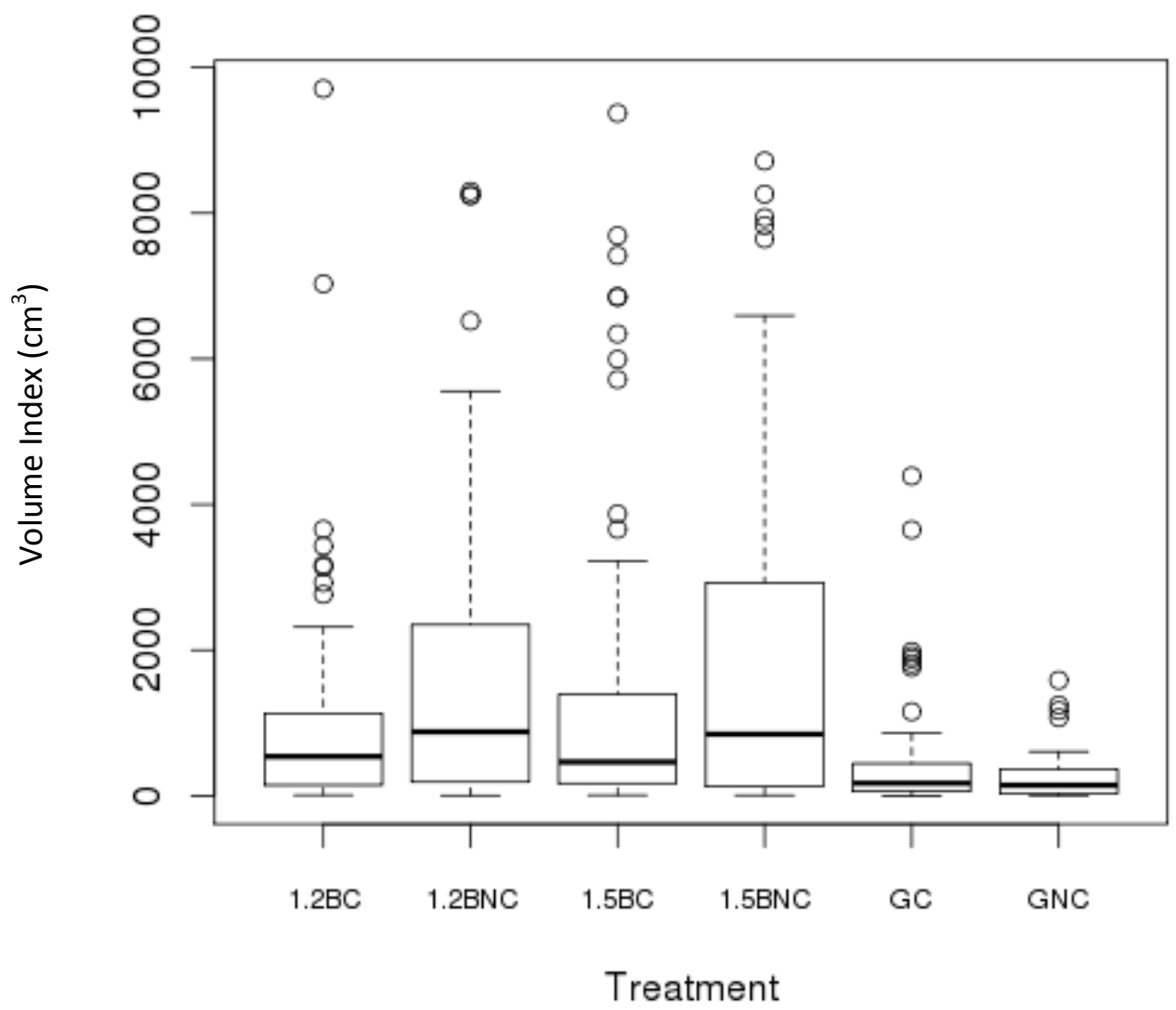

Figure 2-4. Boxplot of black locust volume index 1 for six treatments at Catenary Coal's Samples mine in Boone County, WV in 2012. Black lines within boxes indicate the mean volume index, boxes indicate the upper and lower quartile, and bars outside the box give 99\% of all values (three standard deviations) and circles represent outliers.

Black locust is an early-successional tree that has repeatedly performed well on mined soils (Emerson et al., 2009; Miller et al., 2010). Its excellent performance on mined soils most likely due to its ability to grow on a variety of soil types and its tolerance to a $\mathrm{pH}$ range of 4.6 to 8.2 (Huntley, 1990). Black locust is ecologically important to forest ecosystems because it provides shelter for many animals as well as food for mammals and birds (Larkin et al., 2008). Black locust is also a nitrogen-fixer which helps its own nutrition and provides benefits to drastically disturbed lands by increasing the levels of nitrogen in the soil. 
White oak grows well on a variety of soils derived from many different parent materials and is tolerant of slightly acidic soils (USDA NRCS Plant Guide, 2012). However, it does not grow well on extremely dry, shallow soils (Minkler, 1965). The brown sandstone treatments had a higher percentage of fines than gray sandstone treatments which may increase the water- and nutrient-holding capacity. Miller et al. (2010) found that brown sandstone treatments with fewer coarse rock fragments had more plant-available water than gray sandstone treatments. Soils with more available water have a positive influence on tree productivity which may explain why white oak performed well on the brown sandstone (Table 2-6 and Figure 2-5) (Rodrigue and Burger, 2004).

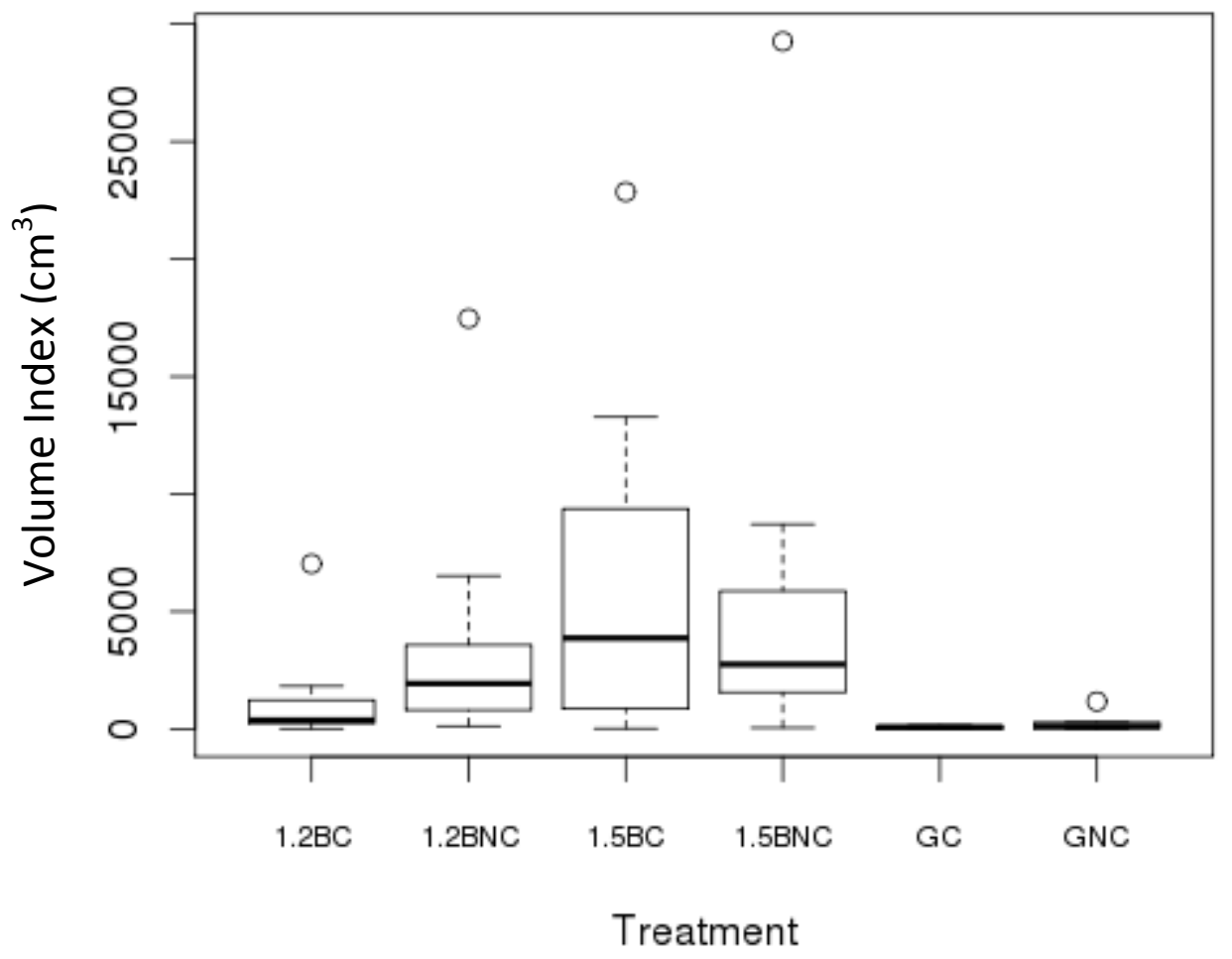

Figure 2-5. Boxplot of white oak volume index 1 for six treatments at Catenary Coal's Samples mine in Boone County, WV in 2012. Black lines within boxes indicate the mean volume index, boxes indicate the upper and lower quartile, and bars outside the box give 99\% of all values (three standard deviations) and circles represent outliers. 
Initially, white pine in this study displayed the lowest survival and the lowest volume across all treatments (Emerson et al., 2009). However, with time it has shown improved growth and persistence on some treatments. White pine has been extensively planted on reclaimed mine sites because of its tolerance to acidic soil $\mathrm{pH}$, however it is intolerant of high levels of soluble salts and shallow soils (Torbert et al., 1988).

White ash had the second highest survival of all species in this study. Similar studies also found that white ash exhibited high survival rates on a variety of mined soils in Kentucky and West Virginia (Miller et al., 2010; Emerson et al., 2009; Zeleznik and Skousen, 1996). Miller et al. (2010) reported that white ash displayed the greatest tree height in brown sandstone treatments vs. gray sandstone, mixed brown-gray sandstone, and shale treatments. In this study, white ash had the highest tree volume on brown sandstone compared to gray sandstone (Table 26 and Figure 2-6).

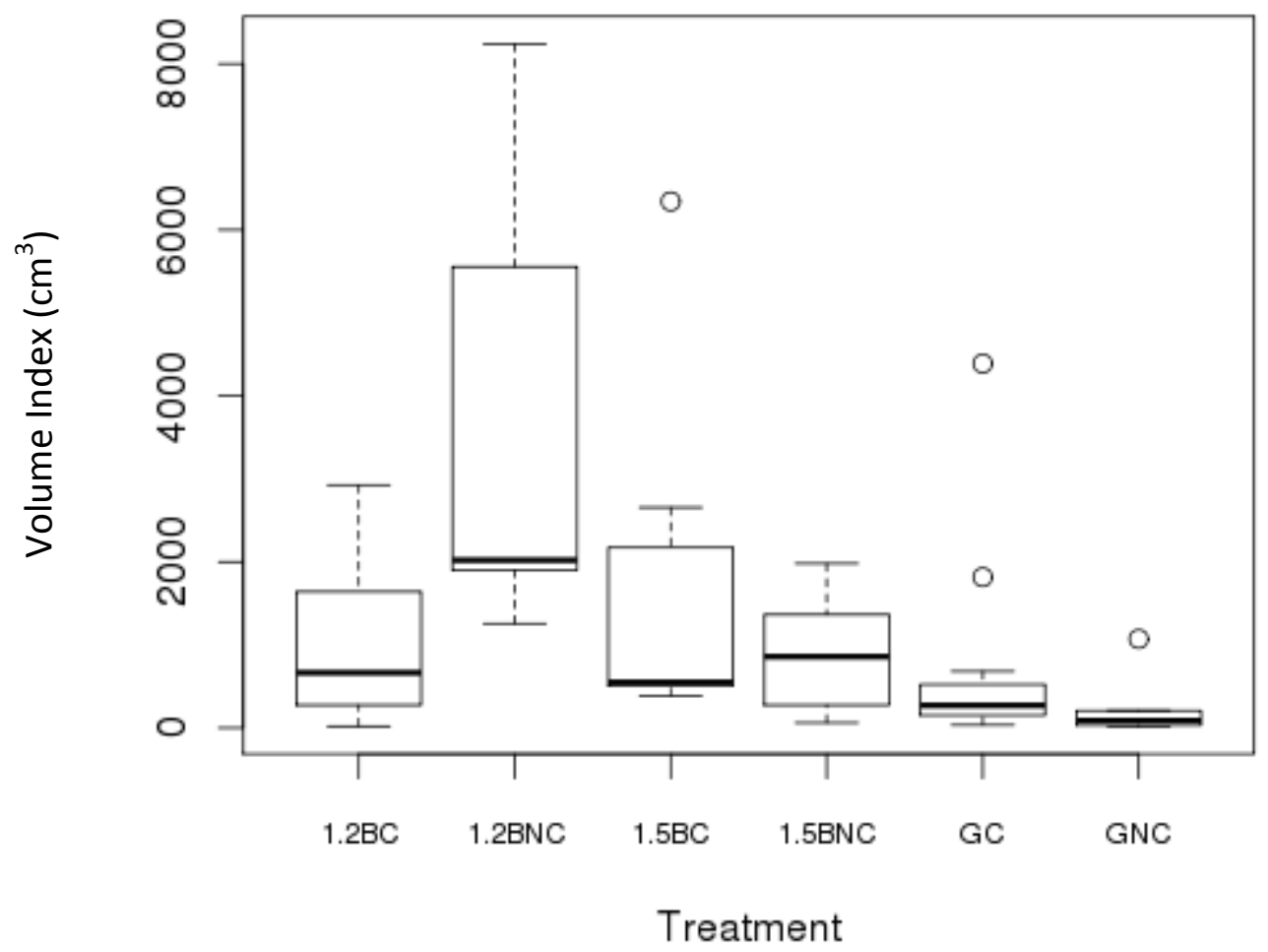

Figure 2-6. Boxplot of white ash volume index 1 on six treatments at Catenary Coal's Samples mine in Boone County, WV in 2012. Black lines within boxes indicate the mean volume index, boxes indicate the upper and lower quartile, and bars outside the box give 99\% of all values (three standard deviations) and circles represent outliers. 
Sugar maple performed the most poorly of all species, with the lowest tree volume index and a very low survival rate. Sugar maple has consistently exhibited poor growth across all treatment combinations in this study (Figure 2-7). While sugar maple trees can tolerate a $\mathrm{pH}$ range of 3.7 to 7.3 , it grows best on soils with $\mathrm{pH} 5.5$ to 7.3. Sugar maples also prefer to grow on deep, moist, and well-drained fine-textured soils (Emerson et al., 2009). Miller et al. (2010) reported that sugar maple grew poorly on both brown sandstone and gray sandstone mine spoils, which was consistent with our findings.

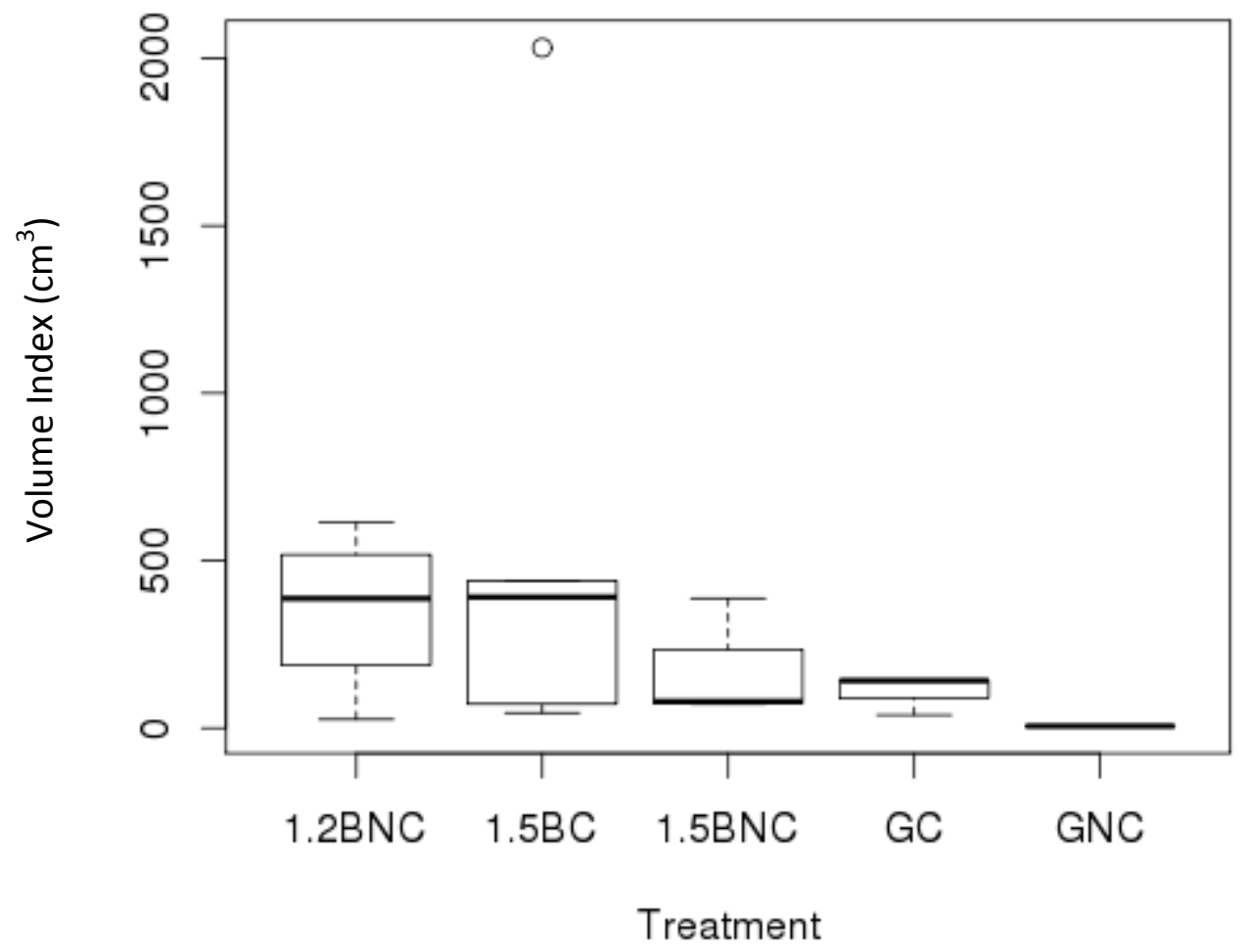

Figure 2-7. Boxplot of sugar maple volume index 1 for five treatments at Catenary Coal's Samples mine in Boone County, WV in 2012. Black lines within boxes indicate the mean volume index, boxes indicate the upper and lower quartile, and bars outside the box give $99 \%$ of all values (three standard deviations) and circles represent outliers. 
After eight growing seasons, trees planted on brown sandstone continued to display significantly higher volume indices than trees planted on gray sandstone. This trend became apparent after the third year (Emerson et al., 2009). All tree species showed a wide range of volume indices within each treatment type. Black locust displayed a wide range of volume indices from 328 to $7407 \mathrm{~cm}^{3}$ while sugar maple had the smallest variation of average tree volume indices ranging from 6 to $596 \mathrm{~cm}^{3}$ (Table 2-6).

Due to planting strategy of the commercial planters, tree species were unevenly distributed among treatments. This uneven distribution of trees among treatments could have misrepresented tree growth in specific treatments because some trees grew larger than others (Table 2-7). If large-growing trees were planted more and over-represented in a particular treatment, the average volume index for that particular treatment may have been significantly higher than another simply because it had more large-growing trees planted within its boundaries. For example, black locust, one of the largest growing trees, had much higher numbers planted in the brown treatment (n from 21 to 40) compared to 7 or less in gray treatments (Table 2-7). A better comparison across treatments to show growth effects may be to look at species with similar numbers across treatments like red oak and white ash. With red oak, clearly all treatments with brown sandstone showed a 10-fold greater tree volume index compared to gray sandstone treatment. For white ash, the trend is not nearly as strong, with only one of the brown sandstone plots (1.2BNC) showing a much greater volume index and noncompacted gray showing a substantially lower index. Overall, however, similar treatments gave similar volume indices. Volume indices for white oak and white pine both show the same trend as red oak with brown sandstone being much greater than gray sandstone. 
Table 2-6. Mean tree volume index ${ }^{¥}$ of tree species in 2012 after eight growing seasons in six soil treatments at Catenary Coal's Samples mine in Boone County, WV.

\begin{tabular}{|c|c|c|c|c|c|c|c|}
\hline \multirow[b]{2}{*}{ Species } & \multicolumn{6}{|c|}{ Treatments § } & \multirow[b]{2}{*}{ Average } \\
\hline & $1.2 \mathrm{BC}$ & 1.2BNC & $1.5 B C$ & 1.5BNC & GC & GNC & \\
\hline & \multicolumn{7}{|c|}{ 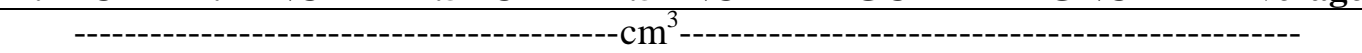 } \\
\hline Black cherry & --- & --- & --- & 930 & 1981 & --- & 1456 \\
\hline Black locust & 4943 & 5324 & 4618 & 7407 & 328 & 413 & 5443 \\
\hline Dogwood & 812 & 2534 & 1027 & 8491 & 1064 & --- & 2517 \\
\hline Redbud & --- & 2058 & 1400 & 358 & 1762 & 376 & 1390 \\
\hline Red oak & 2999 & 3609 & 1838 & 3181 & 397 & 301 & 1923 \\
\hline Sugar maple & --- & 354 & 596 & 154 & 108 & 6 & 314 \\
\hline Tulip-poplar & 687 & 3910 & 154 & 1682 & 284 & 908 & 1238 \\
\hline White ash & 1009 & 3500 & 1487 & 880 & 711 & 218 & 1166 \\
\hline White oak & 1167 & 3027 & 6427 & 5392 & 74 & 285 & 3147 \\
\hline White pine & 2121 & 762 & 6820 & 4646 & 154 & 114 & 2942 \\
\hline Average & 2550 & 3913 & 3556 & 5182 & 449 & 309 & \\
\hline
\end{tabular}

$\S$ see Table 2-1 for treatment descriptions

$¥$ diameter measured at 2.5 -cm above soil surface.

Table 2-7. Distribution of tree species in 2012 after eight growing seasons in six soil treatments at Catenary Coal's Samples mine in Boone County, WV.

\begin{tabular}{|c|c|c|c|c|c|c|c|}
\hline \multirow[b]{2}{*}{ Species } & \multicolumn{6}{|c|}{ Treatments § } & \multirow[b]{2}{*}{ Total } \\
\hline & $1.2 \mathrm{BC}$ & 1.2BNC & $1.5 \mathrm{BC}$ & 1.5BNC & GC & GNC & \\
\hline Black cherry & --- & --- & --- & 1 & 1 & --- & 2 \\
\hline Black locust & 21 & 35 & 29 & 40 & 7 & 1 & 133 \\
\hline Dogwood & 1 & 2 & 3 & 2 & 4 & --- & 12 \\
\hline Redbud & --- & 4 & 2 & 1 & 1 & 2 & 10 \\
\hline Red oak & 8 & 14 & 14 & 10 & 19 & 9 & 74 \\
\hline Sugar maple & --- & 4 & 5 & 4 & 3 & 1 & 17 \\
\hline Tulip-poplar & 5 & 5 & 2 & 4 & 10 & 2 & 28 \\
\hline White ash & 15 & 6 & 13 & 8 & 13 & 8 & 63 \\
\hline White oak & 13 & 17 & 13 & 12 & 8 & 6 & 69 \\
\hline White pine & 6 & 1 & 5 & 1 & 4 & 1 & 18 \\
\hline Total & 69 & 88 & 86 & 83 & 70 & 30 & 426 \\
\hline
\end{tabular}

$\S$ see Table 2-1 for treatment descriptions.

\subsubsection{Soil}

The average $\mathrm{pH}$ for unweathered gray sandstone $(\mathrm{pH}$ 7.9) was significantly higher than the $\mathrm{pH}$ of weathered brown sandstone ( $\mathrm{pH} 5.2$ to 5.7) (Table 2-8). There were no statistically 
significant differences in $\mathrm{pH}$ between compaction treatments, nor were there differences in average $\mathrm{pH}$ when comparing $\mathrm{pH}$ values from 2005 to 2012 within each treatment (Table 2-8). The mean $\mathrm{pH}$ ranges for both sandstone types in this study fell within the typical ranges for weathered and unweathered sandstones in the Appalachian coal region. Weathered brown sandstones typically range in $\mathrm{pH}$ from 4.5 to 5.5 while unweathered gray sandstones fall between 7.5 and 8.0 (Angel et al., 2008; Haering et al., 2004; Thomas and Skousen, 2011).

Electrical conductivity (EC) values for 2012 were all very low, ranging from $0.03 \mathrm{dS} \mathrm{m}^{-1}$ to $0.06 \mathrm{dS} \mathrm{m}^{-1}$ across all treatments (Table 2-8). No significant differences in EC were found for sandstone type, compaction, or treatment interactions. However, the average EC values in 2005 for brown sandstone treatments were significantly higher than average EC values for brown sandstone treatments in 2012 (Table 2-8).

Percent fines were significantly higher in brown sandstone compared to gray sandstone. Average percent fines for brown sandstone plots ranged from 68 to $76 \%$ while gray sandstone ranged from 36 to $41 \%$ (Table 2-8). For compaction, the only significant difference in percent fines between 2005 and 2012 was for the 1.2-m brown sandstone compacted treatment, which gave percent values of 47 in 2005 and 76 in 2012 (Table 2-8).

Table 2-8. Soil properties of samples from six soil treatments at Catenary Coal's Samples mine in Boone County, WV. 2005 soil data are from Emerson et al. (2009).

\begin{tabular}{|c|c|c|c|c|c|c|}
\hline \multirow[b]{2}{*}{ Properties } & \multicolumn{6}{|c|}{ Treatments § } \\
\hline & $1.2 \mathrm{BC}$ & $1.2 \mathrm{BNC}$ & $1.5 \mathrm{BC}$ & $1.5 \mathrm{BNC}$ & GC & GNC \\
\hline $\mathrm{pH}$ & & & & --su--- & & \\
\hline 2005 & $4.7^{\mathrm{c}} \mathrm{f}$ & $5.1^{\mathrm{c}}$ & $5.8^{\mathrm{bc}}$ & $4.6^{\mathrm{c}}$ & $7.3^{\mathrm{a}}$ & $8.2^{\mathrm{a}}$ \\
\hline 2012 & $5.2^{\mathrm{b}}$ & $5.3^{\mathrm{b}}$ & $5.6^{\mathrm{b}}$ & $5.7^{\mathrm{b}}$ & $7.9^{\mathrm{a}}$ & $7.9^{\mathrm{a}}$ \\
\hline $\mathrm{EC}$ & & & & & & \\
\hline 2005 & $* 0.65^{\mathrm{a}}$ & $* 0.29^{\mathrm{ab}}$ & $* 0.46^{\mathrm{ab}}$ & $* 0.48^{\mathrm{ab}}$ & $0.18^{\mathrm{b}}$ & $0.23^{b}$ \\
\hline 2012 & 0.04 & 0.04 & 0.05 & 0.03 & 0.04 & 0.06 \\
\hline Fines & & & & & & \\
\hline 2005 & $* 47^{\mathrm{abc}}$ & $49^{\mathrm{abc}}$ & $53^{\mathrm{ab}}$ & $57^{\mathrm{a}}$ & $40^{\mathrm{bc}}$ & $38^{\mathrm{c}}$ \\
\hline 2012 & $76^{\mathrm{a}}$ & $69^{\mathrm{a}}$ & $69^{\mathrm{a}}$ & $68^{\mathrm{a}}$ & $41^{\mathrm{b}}$ & $36^{\mathrm{b}}$ \\
\hline
\end{tabular}

$\S$ see Table 2-1 for treatment descriptions.

${ }^{\mathrm{t}}$ means for each treatment combination within rows with the same letter are not significantly different at $\mathrm{p}<0.05$.

* denotes significantly different with that property between 2005 and 2012. 
For extractable elements, aluminum, phosphorus, and potassium concentrations were significantly different between brown sandstone and gray sandstone. As expected, compaction was not a significant factor in extractable element concentrations within treatments in 2012 (Table 2-9). The significantly higher levels of aluminum in brown sandstone treatments may be due to the highly weathered nature of the brown sandstone prior to its application in this study compared to the gray sandstone which experienced little weathering. Gray sandstone treatments displayed significantly lower levels of potassium compared to brown sandstone treatments (Table 2-9). While unweathered sandstones are generally thought to provide a long term source of potassium, this study found that the gray sandstone had significantly lower levels of potassium than brown sandstone treatments (Skousen et al., 2011) (Table 2-9). Low levels of potassium in gray sandstone may be due to leaching (Bradshaw, 1997). Extractable phosphorus was significantly greater in gray sandstone than brown sandstone, however, this phosphorus is likely unavailable to plants due to the sorption of phosphorus by the fine soil fractions (Bolland et al., 2003). Extractable nutrients showed significant differences between those measured in 2005 and 2012 and the nutrient levels were not significantly different between years for all treatment combinations. No clear patterns were found for those treatments significantly different between years. 
Table 2-9. Soil properties of samples from six treatments at Catenary Coal's Samples mine in Boone County, WV. 2005 soil data are from Emerson et al. (2009).

\begin{tabular}{|c|c|c|c|c|c|c|}
\hline \multirow[b]{2}{*}{ Elements } & \multicolumn{6}{|c|}{ Treatments $\S$} \\
\hline & $1.2 \mathrm{BC}$ & $1.2 \mathrm{BNC}$ & $1.5 \mathrm{BC}$ & 1.5BNC & GC & GNC \\
\hline & --- & . & $-----c n$ & $\mathrm{~kg}^{-1}-\cdots$ & -- & ---- \\
\hline \multicolumn{7}{|l|}{$\mathrm{Mg}$} \\
\hline 2005 & $* 9.6^{\mathrm{f}}$ & 7.7 & $* 10.3$ & 6.8 & 7.8 & 7.6 \\
\hline 2012 & 4.0 & 4.6 & 4.9 & 5.3 & 6.7 & 6.1 \\
\hline \multicolumn{7}{|l|}{$\mathrm{K}$} \\
\hline 2005 & 0.20 & 0.19 & 0.17 & 0.18 & $* 0.17$ & $* 0.16$ \\
\hline 2012 & $0.37^{\mathrm{a}}$ & $0.51^{\mathrm{a}}$ & $0.50^{\mathrm{a}}$ & $0.42^{\mathrm{a}}$ & $0.07^{\mathrm{b}}$ & $0.03^{\mathrm{b}}$ \\
\hline \multicolumn{7}{|l|}{$\mathrm{Ca}$} \\
\hline 2005 & 2.3 & 2.3 & 2.8 & $* 1.8$ & 3.2 & $* 2.8$ \\
\hline 2012 & 4.7 & 4.9 & 7.1 & 6.8 & 8.4 & 8.9 \\
\hline \multicolumn{7}{|l|}{$\mathrm{Al}$} \\
\hline 2005 & $708^{\mathrm{a}}$ & $626^{\mathrm{ab}}$ & $452^{\mathrm{ab}}$ & $* 593^{\mathrm{ab}}$ & $* 302^{\mathrm{ab}}$ & $* 202^{\mathrm{b}}$ \\
\hline 2012 & $356^{\mathrm{a}}$ & $289^{\mathrm{a}}$ & $256^{\mathrm{a}}$ & $229^{\mathrm{a}}$ & $76^{\mathrm{b}}$ & $81^{\mathrm{b}}$ \\
\hline \multicolumn{7}{|l|}{$\mathrm{Fe}$} \\
\hline 2005 & 430 & $* 873$ & 322 & 357 & 617 & *1054 \\
\hline 2012 & 149 & 134 & 137 & 149 & 203 & 243 \\
\hline \multicolumn{7}{|l|}{$\mathrm{P}$} \\
\hline 2005 & $22^{\mathrm{c}}$ & $23^{\mathrm{c}}$ & $36^{\mathrm{b}}$ & $* 20^{\mathrm{c}}$ & $* 59^{\mathrm{a}}$ & $* 63^{\mathrm{a}}$ \\
\hline 2012 & $44^{\mathrm{b}}$ & $39^{\mathrm{b}}$ & $71^{\mathrm{b}}$ & $56^{\mathrm{b}}$ & $176^{\mathrm{a}}$ & $191^{\mathrm{a}}$ \\
\hline
\end{tabular}

\subsubsection{Ground cover}

After eight growing seasons, vegetative ground cover in 2012 was significantly higher on brown sandstone (70\%) compared to gray sandstone (10\%) (Table 2-10). Inversely, bare soil and rock cover was significantly higher in unweathered gray sandstone treatments (90\%) compared to 22 to $40 \%$ in brown sandstone treatments (Table 2-10). Ground cover was composed of more than just the seeded species on the brown sandstone treatments because this overburden material allowed native plants to re-colonize the site either through the seed bank in the small amount of topsoil in the material or because it provided a better environment for wind-blown or deposited seeds to germinate and establish. The gray sandstone did not provide conditions that allowed invading plants to establish nor did it have a native seed bank. 
Table 2-10. Mean ground cover on six soil treatments in 2012 at Catenary Coal's Samples mine in Boone County, WV.

\begin{tabular}{lcccccc}
\hline & \multicolumn{7}{c}{ Treatment $\$$} \\
\cline { 2 - 7 } Cover & $\mathbf{1 . 2 B C}$ & $\mathbf{1 . 2 B N C}$ & $\mathbf{1 . 5 B C}$ & $\mathbf{1 . 5 B N C}$ & GC & GNC \\
\hline \multirow{2}{*}{ Herbaceous } & $58^{\mathrm{a}} \mathrm{C}$ & $52^{\mathrm{a}}$ & $72^{\mathrm{a}}$ & $58^{\mathrm{a}}$ & $5^{\mathrm{b}}$ & $9^{\mathrm{b}}$ \\
Litter & $1^{\mathrm{b}}$ & $6^{\mathrm{ab}}$ & $1^{\mathrm{b}}$ & $10^{\mathrm{a}}$ & $0^{\mathrm{b}}$ & $0^{\mathrm{b}}$ \\
Tree & 6 & 2 & 5 & 6 & 6 & 1 \\
Total Cover & $65^{\mathrm{a}}$ & $60^{\mathrm{a}}$ & $78^{\mathrm{a}}$ & $74^{\mathrm{a}}$ & $11^{\mathrm{b}}$ & $10^{\mathrm{b}}$ \\
Bare/Rock & $35^{\mathrm{b}}$ & $40^{\mathrm{b}}$ & $22^{\mathrm{b}}$ & $26^{\mathrm{b}}$ & $89^{\mathrm{a}}$ & $90^{\mathrm{a}}$ \\
\hline
\end{tabular}

$\S$ see Table 2-1 for treatment descriptions.

${ }^{\mathrm{f}}$ means for each plot within rows with the same letter are not significantly different at $\mathrm{p}<0.05$.

\subsection{Gray Sandstone Study}

Analysis of tree data for the gray demonstration plot from 2005 to 2011 indicated that growth was extremely poor. When looking at adjacent sites composed of gray sandstone, trees on these sites appeared to be taller and healthier and we wondered if there was a difference between the growth of tress on the gray demonstration plot and nearby areas reclaimed with the same gray sandstone. Therefore, additional areas near our demonstration sites were selected and measured for tree growth. One of the sites was graded and planted, while the other was graded, ripped and planted. All of these sites were planted at the same time and with the same tree species as the demonstration plots. For the purpose of the gray sandstone study, data collected from the compacted and non-compacted sides of the gray sandstone demonstration plot were combined and averaged to represent one 2.8-ha plot to compare to the other two new gray sandstone plots. This was done because data analysis of trees growing on the gray demonstration plot revealed that compaction did not affect soil chemical and physical properties or tree volume index and tree height. Table 2-11 shows the analysis of variance results for selected chemical and physical properties, tree volume index, and tree height between the compacted and non-compacted gray sandstone demonstration plot. As a result of this analysis, tree growth of the two halves of the demonstration plot were combined (2.8-ha area) to compare to the other two 2.8-ha gray plots. The three gray sandstone plots will be referred to as GSS, GCP, and RIP (Table 2-12). 
Table 2-11. ANOVA results for selected soil chemical and physical properties, tree volume index, and tree height on the gray sandstone demonstration plot at Catenary Coal's Samples mine, Boone County, West Virginia.

\begin{tabular}{lcccc}
\hline Category & DF & Sum of Squares & F value & P > F \\
\hline $\mathrm{pH}$ & 1 & 0.00900 & 0.1289 & 0.7288 \\
Electrical conductivity & 1 & 0.0010241 & 0.6132 & 0.4561 \\
Percent fines & 1 & 67.85 & 0.3531 & 0.5688 \\
Tree volume index & 1 & 0.91 & 0.2736 & 0.6021 \\
Tree height & 1 & 0.028 & 0.054 & 0.8168 \\
\hline
\end{tabular}

Table 2-12. Unweathered gray sandstone plots at Catenary Coal's Samples mine in Boone County, West Virginia.

\begin{tabular}{lc}
\hline Plot & Abbreviation \\
\hline Combined gray sandstone demonstration plot & GSS \\
Gray sandstone compacted & GCP \\
Ripped gray sandstone & RIP \\
\hline
\end{tabular}

\subsubsection{Soil}

Average $\mathrm{pH}$ and $\mathrm{EC}$ were not significantly different between the two new gray sandstone plots (GCP and RIP) and the original gray sandstone demonstration plot (GSS) although pH for the GCP and RIP plots displayed a range of values (Figure 2-8). Average $\mathrm{pH}$ for the new gray sandstone plots ranged from 7.3 to 7.4 compared to 7.9 on the GSS (Table 2-13). Electrical conductivity ranged from $0.08 \mathrm{dS} \mathrm{m}^{-1}$ to $0.12 \mathrm{dS} \mathrm{m}^{-1}$ on the new gray plots compared to $0.05 \mathrm{dS}$ $\mathrm{m}^{-1}$ on GSS (Table 2-13). The average percent fines on the RIP plot was 76 while the percent fines on the GSS and the GCP plot ranged from 30 to $41 \%$, respectively (Table 2-13). The significantly greater percent fines was most likely caused by the extra ripping during the reclamation process. Miller et al. (2010) found that gray sandstone rocks exhibited a higher durability in a slake-durability test and were highly resistant to weathering during the freezethaw test. Zipper et al. (2011) reported that soils derived from gray sandstone would continue to have coarse fragments as they age and many hard-grained sandstones have slow decomposition. 
Table 2-13. Soil properties of samples from three gray sandstone plots at Catenary Coal's Samples mine in Boone County, WV.

\begin{tabular}{|c|c|c|c|}
\hline \multirow[b]{2}{*}{ Properties } & \multicolumn{3}{|c|}{ Treatments $\S$} \\
\hline & GSS & GCP & RIP \\
\hline \multirow[t]{2}{*}{$\mathrm{pH}$} & ------- & ---su-- & ----- \\
\hline & $8.0^{\mathrm{a} \mathrm{f}}$ & $7.4^{\mathrm{a}}$ & $7.4^{\mathrm{a}}$ \\
\hline \multirow[t]{2}{*}{$\mathrm{EC}$} & ----- & $---d S_{1}$ & o \\
\hline & $0.05^{\mathrm{a}}$ & $0.12^{\mathrm{a}}$ & $0.08^{\mathrm{a}}$ \\
\hline \multirow[t]{2}{*}{ Fines } & ---- & $\%$ & ------ \\
\hline & $39^{\mathrm{a}}$ & $30^{\mathrm{a}}$ & $76^{\mathrm{b}}$ \\
\hline
\end{tabular}

$\S$ see Table 2-12 for treatment descriptions.

${ }^{\mathrm{t}}$ means for each treatment combination within rows with the same letter are not significantly different at $\mathrm{p}<0.05$.

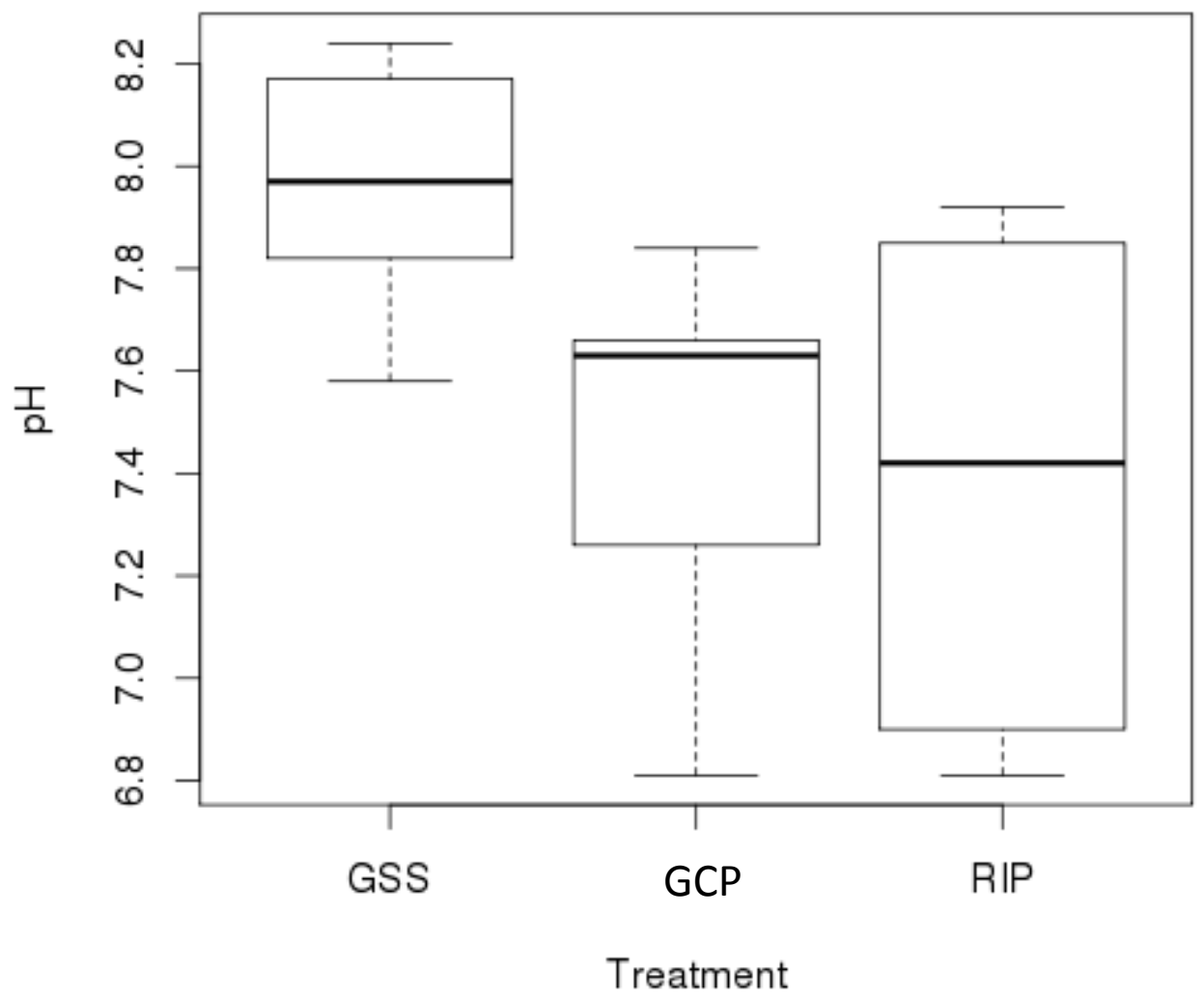

Figure 2-8. Boxplot of soil $\mathrm{pH}$ in samples from three gray sandstone treatments at Catenary Coal's Samples mine in Boone County, WV. Black lines within boxes indicate the mean volume index, boxes indicate the upper and lower quartile, and bars outside the box give $99 \%$ of all values (three standard deviations). 
Aluminum, potassium, and zinc concentrations were significantly different at $\mathrm{p}<0.05$. Aluminum concentrations averaged from 100 to $149 \mathrm{mg} \mathrm{kg}^{-1}$ on the new gray plots compared to $79 \mathrm{mg} \mathrm{kg}^{-1}$ on GSS (Table 2-14). Average potassium concentrations for the new gray plots ranged from 0.18 to $0.55 \mathrm{cmol}_{\mathrm{c}} \mathrm{kg}^{-1}$ and $0.05 \mathrm{cmol}_{\mathrm{c}} \mathrm{kg}^{-1}$ on the gray demonstration plot (Table 214). Zinc concentrations were lower on the new gray plots, 5 to $10 \mathrm{mg} \mathrm{kg}^{-1}$, than on the gray demonstration plot, $16 \mathrm{mg} \mathrm{kg}^{-1}$ (Table 2-14).

Table 2-14. Soil properties from three gray sandstone plots at Catenary Coal's Samples mine in Boone County, WV.

\begin{tabular}{lccc}
\hline & \multicolumn{3}{c}{ Treatments $\$$} \\
\cline { 2 - 4 } Element & GSS & GCP & RIP \\
\hline & $-0.4^{\mathrm{f}}$ & 8.6 & 8.4 \\
$\mathrm{Mg}$ & $0.05^{\mathrm{a}}$ & $0.18^{\mathrm{b}}$ & $0.55^{\mathrm{c}}$ \\
$\mathrm{K}$ & $8.7^{\mathrm{b}}$ & $13.2^{\mathrm{a}}$ & $12.4^{\mathrm{ab}}$ \\
$\mathrm{Ca}$ & $79^{\mathrm{b}}$ & $100^{\mathrm{b}}$ & $149^{\mathrm{a}}$ \\
& 223 & 214 & 322 \\
$\mathrm{Al}$ & 189 & 242 & 272 \\
$\mathrm{Fe}$ & $183^{\mathrm{b}}$ & $273^{\mathrm{a}}$ & $162^{\mathrm{b}}$ \\
$\mathrm{Mn}$ & $16^{\mathrm{a}}$ & $10^{\mathrm{ab}}$ & $5^{\mathrm{b}}$ \\
$\mathrm{P}$ & $\mathrm{yn}$ & & \\
$\mathrm{Zn}$
\end{tabular}

$\S$ see Table 2-12 for treatment descriptions.

${ }^{\mathrm{I}}$ means for each treatment combination within rows with the same letter are not significantly different at $\mathrm{p}<0.05$.

\subsubsection{Ground cover}

Total vegetative cover was significantly higher on the new gray plots than on the gray demonstration plot. Average total vegetative cover ranged from 36 to $47 \%$ on the new gray plots compared to $11 \%$ on the gray demonstration plot (Table 2-15). The gray demonstration plot had the highest percentage of bare soil and rock cover at $89 \%$ while the new gray plots had a bare soil and rock cover at 53 to $64 \%$ (Table 2-15). The gray demonstration plot showed poorer growth conditions than the surrounding gray areas using herbaceous cover as the indicator, which confirmed our observations. 
Table 2-15. Mean ground cover on three gray sandstone plots in 2012 at Catenary Coal's Samples mine in Boone County, WV.

\begin{tabular}{lccc}
\hline Cover & GSS & $\begin{array}{c}\text { Treatments } \S \\
\text { GCP }\end{array}$ & RIP \\
\hline Herbaceous & $7^{\mathrm{b}}$ & $32^{\mathrm{a}}$ & $40^{\mathrm{a}}$ \\
Litter & $0^{\mathrm{b}}$ & $3^{\mathrm{a}}$ & $5^{\mathrm{a}}$ \\
Tree & 4 & 1 & 2 \\
Total Cover & $11^{\mathrm{b}}$ & $36^{\mathrm{a}}$ & $47^{\mathrm{a}}$ \\
Bare/Rock & & & $53^{\mathrm{a}}$ \\
\hline
\end{tabular}

$\S$ see Table 2-12 for treatment descriptions.

${ }_{\mathrm{t}}$ means for each plot within rows with the same letter are not significantly different at $\mathrm{p}<0.05$.

\subsubsection{Trees}

Average tree volume indices for the new gray sandstone plots and the gray sandstone demonstration plot were not significantly different at $\mathrm{p}<0.05$ (Table 2-16). However, average tree volume for the new gray plots (GCP and RIP) ranged from 885 to $909 \mathrm{~cm}^{3}$ while the gray demonstration plot (GSS) averaged $407 \mathrm{~cm}^{3}$ (Table 2-17), essentially a doubling of the tree volume index. However, average tree heights displayed a slight significant difference. The average tree height on the new gray plots was higher, 83 to $91 \mathrm{~cm}$, compared to the gray demonstration plot, $70 \mathrm{~cm}$ (Table 2-17). The GCP and RIP plots had slightly wider range of tree heights than the GSS plot (Figure 2-9).

Table 2-16. ANOVA results for mean tree volume and mean height on three gray sandstone plots at Catenary Coal's Samples mine in Boone County, WV.

\begin{tabular}{lcccc}
\hline Category & DF & Sum of Squares & F value & P > F \\
\hline Tree volume index & 2 & 0.46 & 0.0689 & 0.9334 \\
Tree height & 2 & 21074 & 2.944 & 0.0495 \\
\hline
\end{tabular}


Table 2-17. Mean tree volume index ${ }^{¥}$ and height on three gray sandstone plots at Catenary Coal's Samples mine in Boone County, WV.

\begin{tabular}{lccc}
\hline & \multicolumn{3}{c}{ Treatment $\S$} \\
\cline { 2 - 4 } & GSS & GCP & RIP \\
\hline Volume Index $\left(\mathrm{cm}^{3}\right)$ & $407^{\mathrm{a} \mp}$ & $909^{\mathrm{a}}$ & $885^{\mathrm{a}}$ \\
& $70^{\mathrm{b}}$ & & $93^{\mathrm{ab}}$ \\
\hline
\end{tabular}

$\S$ see Table 2-12 for treatment descriptions

$¥$ tree diameter measured at 2.5 -cm above soil surface

${ }^{\mathrm{f}}$ means for each volume and height within columns with the same letter are not significantly different at $\mathrm{p}<0.05$

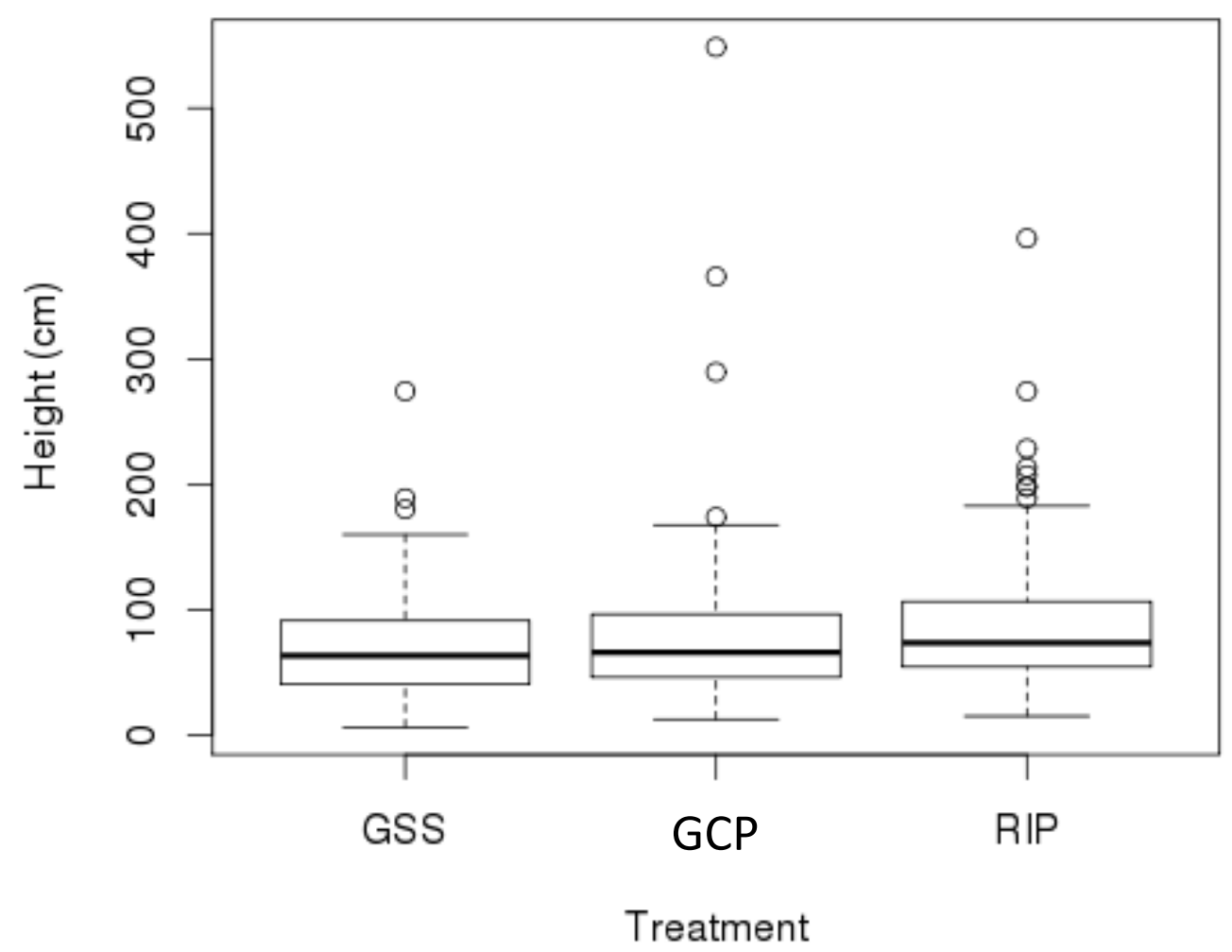

Figure 2-9. Boxplot of tree heights measured on three gray sandstone treatments in 2012 at Catenary Coal's Samples mine in Boone County, WV. Black lines within boxes indicate the mean height, boxes indicate the upper and lower quartile, and bars outside the box give $99 \%$ of all values (three standard deviations) and circles represent outliers. 
Without knowing the number of trees that were originally planted on the two new gray plots, it is impossible to determine the survival rate of tree species or to make a comparison between numbers of trees measured on the new gray plots compared to numbers of trees measured on the original gray demonstration plot. Again, not all species are represented in each plot. Table 2-18 shows the distribution of tree species within each gray sandstone plot and Table 2-19 shows average tree volume index for individual species within each gray sandstone plot.

White ash was the only species which had a reasonable number of live specimens on each plot (> 20). Mean tree volume index was almost identical on the GSS and RIP plots, $523 \mathrm{~cm}^{3}$ and $530 \mathrm{~cm}^{3}$, respectively. The GCP plot had a mean volume index of only $298 \mathrm{~cm}^{3}$ although it is unclear as to why the volume index is lower on this plot compared to the GSS and RIP plots.

Table 2-18. Distribution of tree species on three gray sandstone plots in 2012 at Catenary Coal's Samples mine in Boone County, WV.

\begin{tabular}{lcccc}
\hline & \multicolumn{3}{c}{ Treatments $\$$} & Total \\
\cline { 2 - 4 } Species & GSS & GCP & RIP & 8 \\
\hline Black cherry & 1 & 6 & 21 & 37 \\
Black locust & 8 & 8 & --- & 4 \\
Dogwood & 4 & --- & 2 & 5 \\
Redbud & 3 & --- & 6 & 59 \\
Red oak & 28 & 25 & 8 & 12 \\
Sugar maple & 4 & --- & 22 & 39 \\
Tulip-poplar & 12 & 5 & 28 & 73 \\
White ash & 21 & 24 & 8 & 47 \\
White oak & 14 & 25 & 2 & 9 \\
White pine & 5 & 2 & 98 & 293 \\
Total & 100 & 95 & & \\
\hline
\end{tabular}

$\S$ see Table 2-12 for treatment descriptions 
Table 2-19. Mean tree volume index ${ }^{¥}$ of tree species in 2012 on three gray sandstone plots at Catenary Coal's Samples mine in Boone County, WV.

\begin{tabular}{|c|c|c|c|c|}
\hline \multirow[b]{2}{*}{ Species } & \multicolumn{3}{|c|}{ Treatments $\S$} & \multirow[b]{2}{*}{ Average } \\
\hline & GSS & GCP & RIP & \\
\hline Black cherry & 1981 & 149 & 289 & 395 \\
\hline Black locust & 338 & 7664 & 2407 & 3096 \\
\hline Dogwood & 1064 & --- & --- & 1064 \\
\hline Redbud & 837 & --- & 1127 & 953 \\
\hline Red oak & 366 & 468 & 217 & 394 \\
\hline Sugar maple & 82 & -- & 71 & 75 \\
\hline Tulip-poplar & 388 & 78 & 285 & 290 \\
\hline White ash & 523 & 298 & 530 & 452 \\
\hline White oak & 164 & 187 & 1112 & 338 \\
\hline White pine & 146 & 146 & 874 & 308 \\
\hline Average & 407 & 909 & 885 & \\
\hline
\end{tabular}

$\S$ see Table 2-12 for treatment descriptions

$\stackrel{*}{*}$ tree diameter measured at 2.5 -cm above soil surface

With time, tree growth on the RIP plot may surpass tree growth on the GCP plot and the original GSS demonstration plot based on the results of Burger and Evans (2010) who studied the effects of ripping on tree growth 18 years after reclamation. The higher percentage of fines could increase the soil's plant-available water which would positively influence the site's productivity (Rodrigue and Burger, 2004). Skousen et al. (2009) found that black walnut seeds had a significantly greater establishment and survival on a ripped surface mine in West Virginia vs. a non-ripped treatment on the same site. On a surface coal mine in eastern Kentucky, Burger and Evans (2010) found that tree survival and tree volume were greatly improved by ripping. However, while ripping helps alleviate some of the physical limitations associated with traditional reclamation processes, compaction during soil placement should be avoided whenever possible (Burger and Evans, 2010).

\subsection{Conclusions}

Trees grown on weathered brown sandstone exhibited a higher level of performance than trees grown on unweathered gray sandstone over an 8-year period. Results during the previous seven years of this study found no differences in tree survival between brown and gray sandstone plots, but data from 2012 found tree survival to be higher on brown compared to gray sandstone 
plots. Weathered brown sandstone is more conducive to the growth and survival of native hardwood tree species than unweathered gray sandstone at this stage of development and is a more suitable topsoil substitute than gray sandstone when reforestation is the post-mining land use. Although previous reports on this study found that compaction did not significantly impact tree volume index, the data collected in 2012 suggested that compaction has begun to limit tree growth. The chemical properties of the brown sandstone are more conducive for supporting a variety of tree species than chemical properties associated with gray sandstone.

The gray sandstone comparative study revealed that there was no significant difference between the two adjacent plots and the original gray sandstone plot with respect to tree growth thus reinforcing that brown sandstone is a more suitable rooting medium for hardwood trees. 


\subsection{Literature Cited}

Angel, P.N., D.H. Graves, C. Barton, R.C. Warner, P.W. Conrad, R.J. Sweigard, and C. Agouridis. 2006. Surface mine reforestation research: Evaluation of tree response to low compaction reclamation techniques. p. 45-58. In: Barnhisel, R. (ed.), Proceedings, 2006 American Society of Mining and Reclamation. March 26-30, 2006, St. Louis, MO.

Angel, P., C. Barton, R. Warner, C. Agouridis, T. Taylor, and S. Hall. 2008. Forest establishment and water quality characteristics as influenced by spoil type on a loosegraded surface mine in eastern Kentucky. p. 28-65. In: Barnhisel, R. (ed.), Proceedings, 2008 American Society of Mining and Reclamation. June 4-8, 2008. Richmond, VA.

Ashby, W.C. 1996. Red oak and black walnut growth increased with mine soil ripping. International J. Surface Mining, Recl. Environ., 10: 113-116.

Ashby, W.C. 1997. Soil ripping and herbicides enhance tree and shrub restoration on stripmines. Restoration Ecol. 5: 169-177.

Bolland, M.D.A., D.G. Allen, and N.J. Barrow. 2003. Sorption of phosphorus by soils. Dept. of Ag. Gov. of Western Australia. ISSN 1448-0352. Bunbury, Western Australia.

Bradshaw, A. 1997. Restoration of mined lands using natural processes. Ecol. Engineering 8: $255-269$.

Brady, N.C. and R.R. Weil. 2002. The nature and properties of soil. Thirteenth ed. Prentice Hall, Upper Saddle River, N.J.

Burger, J.A. 1999. Academic research perspective on experiences, trends, constraints and needs related to reforestation of mined land. p. 63-74. In: Proceedings, Enhancement of Reforestation at Surface Coal Mines: Technical Interactive Forum, March 23-24, 1999. Fort Mitchell, KY.

Burger, J.A. and A.G. Fannon. 2009. Capability of reclaimed mined land for supporting reforestation with seven Appalachian hardwood species. p. 176-191. In: Barnhisel, R. (ed), Proceedings, 2009 American Society of Mining and Reclamation, May 30 - June 5, 2009. Billings, MT. 
Burger, J.A. and D.M. Evans. 2010. Ripping compacted mine soils improved tree growth 18 years after planting. p. 55-69. In: Barnhisel, R. (ed), Proceedings, 2010 American Society of Mining and Reclamation, June 5-11, 2010. Pittsburgh, PA.

Coder, K.D. 1998. Tree root growth control series: Soil constraints on root growth. University of Georgia Cooperative Extension Service, Forest Resources Publication FOR 98-10. Athens, GA.

Conlin, T.S.S. 1996. Soil compaction studies. FRDA Rep. No. 264. Canadian Forest Service, Victoria, BC. Available at http://www.openlibrary.org/works/OL12325828W. Accessed 28 March 2013.

DeLong, C. 2010. Evaluation of reforestation efforts on two reclaimed surface mines in West Virginia. M.S. Thesis, West Virginia University, Morgantown, WV.

DeLong, C., J. Skousen, E. Pena-Yewtukhiw. Bulk density of rocky mine soils in forestry reclamation. Soil Sci. Soc. Am. J. 76: 1810-1815.

Emerson, P., J. Skousen, and P. Ziemkiewicz. 2009. Survival and growth of hardwoods in brown versus gray sandstone on a surface mine in West Virginia. J. Environ. Qual. 38: 18211829.

Google Maps. 2012. Commonwealth of Virginia. DigitalGlobe, GeoEye. USDA Farm Service Agency. Available at http://maps.google.com/maps?hl=en\&tab=wl. Accessed 25 March 2013.

Haering, K.C., W.L. Daniels, and J.M. Galbraith. 2004. Appalachian mine soil morphology and properties: Effects of weathering and mining method. Soil Sci. Soc. Am. J. 68: 13151325.

Huntley, J. C. 1990. Robinia pseudoacacia L. black locust. p. 755-761. In: Burns, R.M.; Honkala, B.H., (eds.), Silvics of North America. Volume 2. Hardwoods. Agric. Handb. 654. U.S. Department of Agriculture, Forest Service, Washington, DC. 
Jordon, D., J.F. Ponder, and V.C. Hubbard. 2003. Effects of soil compaction, forest leaf litter and nitrogen fertilizer on two oak species and microbial activity. Appl. Soil Ecol. 23: $33-41$.

Larkin, J.L., D. Maehr, J. Krupa, J. Cox, K. Alexy, D. Unger, and C. Barton. 2008. Small mammal response to vegetation and spoil conditions on a reclaimed surface mine in Eastern Kentucky. Southeastern Naturalist 7: 401-412.

McFee, W.W., W.R. Byrnes, and J.G. Stockton. 1981. Characteristics of coal mine overburden important to plant growth. J. Environ. Qual. 10: 300-308.

Miller, J., C. Barton,C. Agourdis, A. Fogel, T. Dowdy, and P. Angel. 2010. Evaluating soil genesis and reforestation success on a surface coal mine in Appalachia. Soil Sci. Soc. Am. J. 76: 950-960.

Minkler, L.S. 1965. White oak (Quercus alba L.). p. 632-637. In: Silvics of Forest Trees of the United States. Agric. Handb 271. U.S. Department of Agriculture, Forest Service, Washington, DC.

R Development Core Team. 2012. R: A language and environment for statistical computing, reference index version 2.13.0. R Foundation for Statistical Computing, Vienna, Austria. ISBN 3-90051-08-9, URL http://www.R-project.org. Accessed 15 February 2013.

Rodrigue, J.A. and J.A. Burger. 2004. Forest soil productivity of mined land in the midwestern and eastern coalfield regions. Soil Sci. Soc. Am. J. 68: 833-844.

Showalter, J.M., J.A. Burger, and C.E. Zipper. 2010. Hardwood seedling growth on different mine spoil types with and without amendment. J. Environ. Qual. 39: 483-491.

Skousen, J., J. Gorman, E. Pena-Yewtukhiw, J. King, J. Stewart, P. Emerson, and C. DeLong. 2009. Hardwood tree survival in heavy ground cover on reclaimed land in West Virginia: mowing and ripping effects. J. Environ. Qual. 38: 1400-1409.

Skousen, J., C. Zipper, J. Burger, P. Angel, and C. Barton. 2011. Selecting topsoil substitutes for forestry mine soils. p. 591-609. In: Barnhisel, R. (ed), Proceedings, 2011 American Society of Mining and Reclamation, June 11-16, 2011. Bismarck, ND. 
Skousen, J., C. Zipper, J. Burger, C. Barton, and P. Angel. 2011. Selecting materials for mine soil construction when establishing forests on Appalachian mine sites. Forest Reclamation Advisory No. 8. July 2011. Available at http://arri.osmre.gov/Publications/Publications.shtm. Accessed 28 March 2013.

Thomas, C., and J. Skousen. 2011. Hardwood tree performance on amended brown and gray mine spoils after four years. p. 655-675. In: Barnhisel, R. (ed.), Proceedings, 2011 American Society of Mining and Reclamation, June 12-16, 2011. Bismarck, ND.

Torbert, J.L., A.R. Tuladhar, J.A. Burger, and J.C. Bell. 1988. Mine soil property effects on the height of 10-year-old white pine. J. Environ. Qual. 17: 189-192.

Torbert, J.L., J.A. Burger, and W.L. Daniels. 1990. Pine growth variation with overburden rock type on a reclaimed surface mine in Virginia. J. Environ. Qual. 19: 88-92.

Tyner, E.H., R.M. Smith, and S.L. Galpin. 1948. Reclamation of strip-mined areas in West Virginia. J. Am. Soc. Agron. 40: 313-323.

United States Department of Agriculture, Natural Resources Conservation Service. 2012. PLANTS Database. Available at http://plants.usda.gov/java/. Accessed 28 March 2013.

Zeleznik, J., and J. Skousen. 1996. Survival of three tree species on old reclaimed surface mines in Ohio. J. Environ. Qual. 25: 1429-1435.

Zipper, C.E., J.A. Burger, J.M. McGrath, J.A. Rodrigue, G.I. Holtzman. 2011. Forest restoration potentials of coal-mined lands in the eastern United States. J. Environ. Qual. 40: 1567-1577. 


\section{Birch River mine}

\subsection{Literature Review and Objectives}

The addition of organic soil amendments has been a common practice in agriculture dating back to the Roman Empire (Parr and Hornick, 1992). Organic soil amendments were and are used to improve soil physical properties, such as water retention, permeability, water infiltration, drainage, aeration and structure as well as add organic matter and nutrients. Many surface-mined sites lack sufficient organic matter to support optimum soil function (Bendfeldt et al., 2001). Several studies have shown that mine soils exhibit limited nitrogen and phosphorus availability, micronutrient imbalances, high electrical conductivity, and low water holding capacity (Daniels and Zipper, 1988; Torbert et al., 1989; Torbert et al., 1988), all of which are influenced by the low amount of organic matter in these soils.

The application of soil amendments to reclaimed mine sites can improve tree growth. Bark mulch helps to deter erosion, provides soil nutrients, protects seeds and seedlings, and helps retain moisture for plant uptake (Conrad et al., 2008). Angel et al. (2006) found the addition of organic soil supplements (hardwood bark mulch and composted straw and manure) improved tree growth by adding nutrients to the soil. Showalter et al. (2010) found the addition of forest topsoil to unweathered shale improved the growth of native hardwood trees. It was reported that forest topsoil significantly increased mineralizable nitrogen from 0.35 to $4.24 \mathrm{mg} \mathrm{kg}^{-1}$ compared with unweathered shale. Thomas and Skousen (2011) reported that the application of bark mulch to brown and gray sandstone doubled the overall tree volume index on brown sandstone and increased tree volume index four times on gray sandstone. In addition to providing soil nutrients, the application of soil amendments such as bark mulch to mine soils may reduce levels of iron by forming metal complexes with the organic matter (Harman et al., 2007).

Aside from soil amendments, organic matter inputs from herbaceous vegetation can have a positive influence on mine soil properties. Bendfeldt et al. (2001) reported that a lowcompetition herbaceous vegetation planted 16 years previously on a reclaimed surface mine in Virginia resulted in organic matter and $\mathrm{N}$ mineralization potential values comparable to levels in organically-amended plots on the same site. Another reason for establishing an herbaceous cover for reforestation is that it protects the soil from sunlight allowing for the development of soil fauna (Neumann, 1973). Herbaceous vegetation also helps control erosion on surface mined 
sites. Loch (2000) demonstrated that a minimum ground cover of 50\% drastically reduced runoff and erosion when compared to bare soil. Fields-Johnson et al. (2010) reported that plots on a surface mine in Virginia hydroseeded with a conventional mix experienced a surface soil loss of $7 \mathrm{~mm}$ over two growing seasons compared to a surface soil accumulation of $2 \mathrm{~mm}$ in plots hydroseeded with a tree compatible mix. Therefore, it is important to establish a permanent vegetative ground cover on mined lands to add organic matter, aid in the establishment of soil fauna, and deter soil erosion.

It has been observed in other studies, however, that aggressive herbaceous species planted on mined soils, while improving soils with organic matter additions, can impede the growth and survival of tree seedlings (Rodrigue and Burger, 2004; Holl, 2002). The FRA recommends using tree-compatible ground cover such as birdsfoot trefoil (Lotus corniculatus L.), ladino clover (Trifolium repens L.), redtop (Agrostis gigantea Roth), and perennial ryegrass (Lolium perenne L.) when reforestation is the assigned post-mining land use in order to minimize soil moisture competition and to allow for sufficient light penetration for tree seedling growth (Fields-Johnson et al., 2010; Franklin et al., 2012). One study found that planting lowcompetition herbaceous species promoted the colonization of volunteer, native, non-invasive herbaceous species on a reclaimed surface mine in Virginia (Fields-Johnson et al., 2012). This study suggested that the colonization of native species allows for accelerated natural succession. Thomas and Skousen (2011) found that when hydroseeding a mined site with a tree-compatible ground cover at a rate of $35.8 \mathrm{~kg} \mathrm{ha}^{-1}$, there were no negative effects on tree growth after four years. Fields-Johnson et al. (2010) reported a higher tree survival rate in areas seeded with a treecompatible mix $(71 \%)$ versus a conventional mix $(65 \%)$.

The objectives of this study were to determine the effects of a soil amendment and hydroseeding to topsoil substitutes on tree growth and survival. Over a six-year period, soil chemical properties were determined on all treatments and the establishment and growth of 12 hardwood species were determined on brown and gray plots with and without bark mulch, and with and without hydroseeding. 


\subsection{Methods}

\subsubsection{Study Site}

The study site is located near Cowen, West Virginia in Webster County approximately $200 \mathrm{~km}$ southwest of Morgantown, WV (38²6'33.324" N 080 36'41.4" W). The Birch River mine is approximately 1,620 ha and is operated by Arch Coal. In November 2006, a 2.8-ha experimental plot was established using two different substrates. Half of the plot was constructed with approximately $1.5 \mathrm{~m}$ of brown sandstone and the other half with approximately $1.5 \mathrm{~m}$ of gray sandstone. Measures were taken to limit compaction via one pass of the bulldozer which resulted in a 1.2-m depth of roughly graded material throughout the plot. The following spring, a 15-cm layer of bark mulch was applied to a small area over the top of both sandstone substrates. Twelve tree species were then planted on 2.4-m centers by a professional planting crew for a stocking rate of about 1,450 trees per ha (Table 3-1). In the fall of 2007, both ends of the plot were hydroseeded with a mix of tree compatible herbaceous vegetation at a rate of $35.7 \mathrm{~kg} \mathrm{ha}^{-1}$ (Table 3-2) and then fertilized with 10-20-10 NPK at a rate of $336 \mathrm{~kg} \mathrm{ha}^{-1}$. Overall, eight treatments were created (Table 3-3). Figure 3-1 illustrates the treatments and transects used for sampling. 
Table 3-1. Species and number of trees planted in 2007 at the Arch- Birch River mine in Webster County, West Virginia.

\begin{tabular}{lcc}
\hline Species & Number of trees planted & Percent of trees planted \\
\hline Black cherry (Prunus serotina Ehrh.) & 425 & 11 \\
Northern red oak (Quercus rubra L.) & 425 & 11 \\
Sugar maple (Acer saccharum Marsh.) & 425 & 11 \\
White ash (Fraxinus americana L.) & 425 & 11 \\
White oak (Quercus alba L.) & 425 & 11 \\
Black locust (Robinia psuedoacacia L.) & 400 & 10 \\
Pitch X loblolly pine (Pinus X rigitaeda) & 400 & 10 \\
Tulip-poplar (Liriodendron tulipifera L.) & 300 & 8 \\
Sycamore (Platanus occidentalis L.) & 225 & 6 \\
Eastern white pine (Pinus strobus L.) & 200 & 5 \\
Dogwood (Cornus alternifolia L.) & 175 & 4 \\
Eastern redbud (Cercis canadensis L.) & 175 & 4 \\
Total & 4,000 & 100 \\
\hline
\end{tabular}

Table 3-2. Species and rate of application of ground cover hydroseeded in 2007 at Arch- Birch River mine in Webster County, West Virginia.

\begin{tabular}{lc}
\hline Species & Rate \\
\hline & $\mathrm{kg} \mathrm{ha}^{-1}$ \\
Birdsfoot trefoil (Lotus corniculatus L.) & 11.2 \\
Kobe lespedeza (Kummerowia striata Maxim.) & 5.6 \\
Ladino clover (Trifolium repens L.) & 3.3 \\
Orchard grass (Dactylis glomerata L.) & 5.6 \\
Perennial ryegrass (Lolium perenne L.) & 5.6 \\
Redtop (Agrostis gigantea Roth) & 2.2 \\
Weeping lovegrass (Eragrostis curvula Schra.) & 2.2 \\
Total & 35.7 \\
\hline
\end{tabular}


Table 3-3. Soil treatment combinations at Arch Coal's Birch River mine in Webster County, WV.

\begin{tabular}{lc}
\hline Treatment & Abbreviation \\
\hline Brown sandstone & $\mathrm{B}$ \\
Brown sandstone with mulch & $\mathrm{BM}$ \\
Brown sandstone with mulch and hydroseeding & $\mathrm{BMH}$ \\
Brown sandstone with hydroseeding & $\mathrm{BH}$ \\
Gray sandstone & $\mathrm{G}$ \\
Gray sandstone with mulch & $\mathrm{GM}$ \\
Gray sandstone with mulch and hydroseeding & $\mathrm{GMH}$ \\
Gray sandstone with hydroseeding & $\mathrm{GH}$ \\
\hline
\end{tabular}




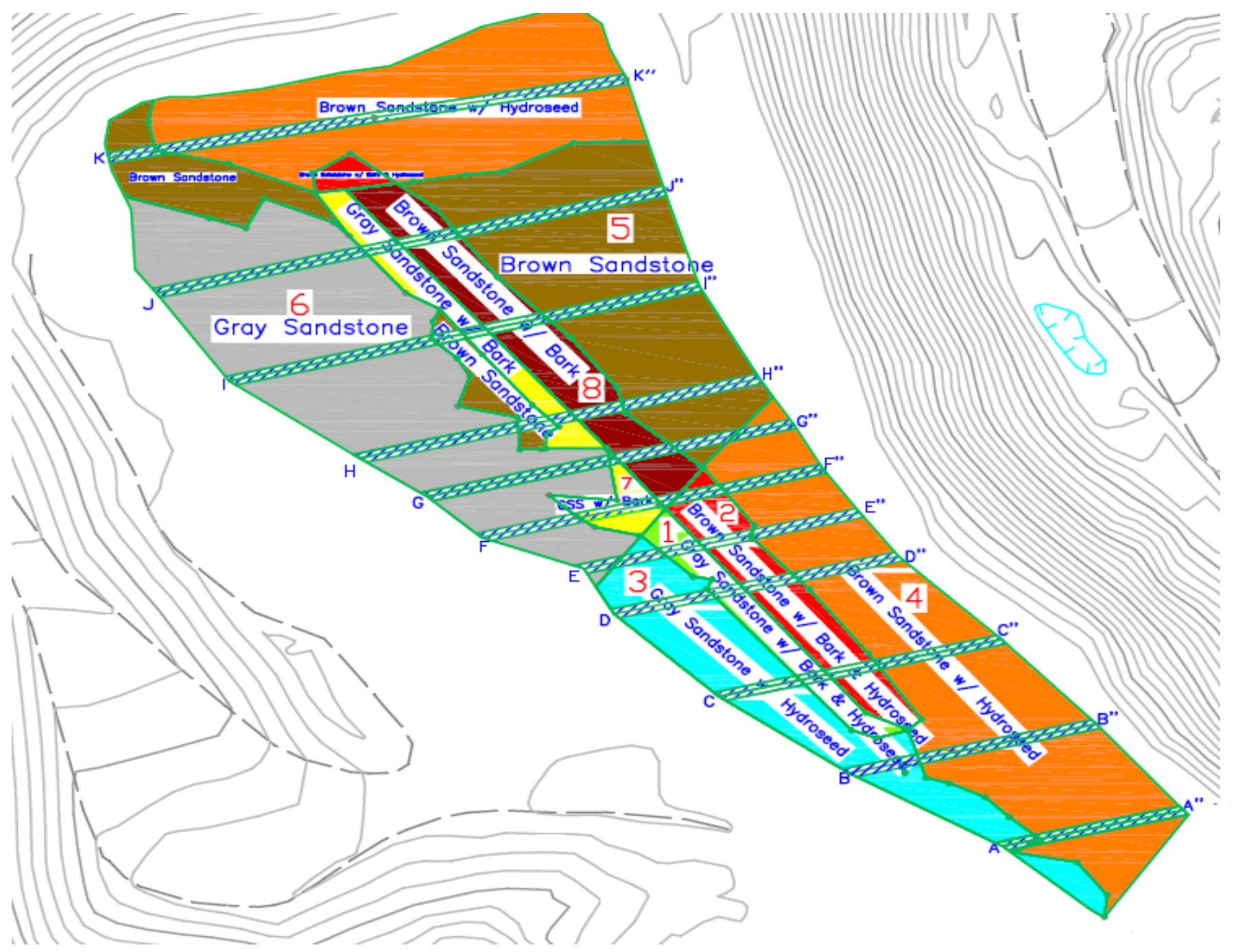

Figure 3-1. Eight treatments were established at the Arch - Birch River mine in Webster County, West Virginia. Eleven ("A" to " $K$ ") transects were placed to cross the various treatments, and trees and soils were measured within transects.

\subsubsection{Trees}

Tree volume index and survival were determined with the use of eleven 2.7-m wide transects spanning the width of the plot. All trees within the 2.7-m wide transect were identified and measured for height and diameter. Tree height was measured to highest live growth and diameter was measured at $2.5 \mathrm{~cm}$ above the soil surface. Tree growth was assessed using a tree volume index with the formula:

Tree volume index $\left(\mathrm{cm}^{3}\right)=$ Tree height $(\mathrm{cm})$ x Stem diameter $\left(\mathrm{cm}^{2}\right)($ Emerson et al., 2009) 
Percent tree survival was determined by finding the difference between the number of trees samples in the first year, 2008, and the current year, 2012. Tree sampling was conducted during late July to early August each year.

During summer 2012, tree diameter was measured at $10 \mathrm{~cm}$ and $2.5 \mathrm{~cm}$ above the soil surface. In previous years, tree seedlings at the experimental site were measured for diameter at $2.5 \mathrm{~cm}$ but as the trees grow taller, diameter should be measured at a higher point on the tree stem until they reach the appropriate height to begin using DBH. For the purpose of this study, all references to volume index will specifically refer to volume index measured at $2.5 \mathrm{~cm}$ (Volume Index 1) although volume indices measured at $10 \mathrm{~cm}$ (Volume Index 2) are included in Table 3-4.

\subsubsection{Soil}

Soil samples were collected from the top $15 \mathrm{~cm}$ at four randomly selected points along transects within each treatment type for a total of 32 samples every year beginning in 2008 . The collected soil samples were air dried, weighed, and sieved to pass through a 2-mm screen. The fine soil fraction $(<2 \mathrm{~mm})$ was used to determine $\mathrm{pH}$, extractable nutrients, and electrical conductivity.

Soil $\mathrm{pH}$ was determined using $5 \mathrm{~g}$ of soil with $5 \mathrm{ml}$ of DDI water with a Fisher Scientific Accumet pH meter model 915 (Thermo Fisher Scientific Inc., Pittsburgh, PA). Electrical conductivity (EC) was determined using a 1:2 mixture comprised of $5 \mathrm{~g}$ of soil and $10 \mathrm{~mL}$ of DDI water on a Mettler Toledo S230 EC Meter (Mettler-Toledo International Inc., Columbus, $\mathrm{OH})$. Extractable nutrients were determined using a Mehlich 1 extracting solution (0.025 N $\mathrm{H}_{2} \mathrm{SO}_{4}+0.05 \mathrm{~N} \mathrm{HCl}$ ). The extracted solution was analyzed for potassium, calcium, magnesium, manganese, phosphorus, iron, aluminum, and zinc using a Perkin Elmer Optima DV 2100 emission spectrophotometer (Perkin-Elmer Corp., Norwalk, CT).

\subsubsection{Ground Cover}

Percentage of ground cover was evaluated within a $1-\mathrm{m}^{2}$ quadrat which was placed at five randomly selected points along transects within each treatment type. Percent herbaceous cover, 
litter cover, tree cover, standing water, bare soil, and rocks were estimated to the nearest five percent.

\subsubsection{Statistical Analysis}

Data for tree volume index were analyzed using a General Linear Model to compare substrate, amendment, interactions, and species. Tukey's Honest Significant Difference (HSD) was used to separate treatment means at $\mathrm{p}<0.05$. Tree volume index data contained unequal variances so volume data were log transformed to equalize the variances. Soil data were analyzed by one-way ANOVA by treatment combinations within year for $\mathrm{pH}$, EC, extractable elements, and percent fines. Tukey's HSD test was used to determine significant differences at a level of $\mathrm{p}<0.05$. Percent ground cover data were analyzed by one-way ANOVA by treatment type. Tukey's HSD test was used to determine significant differences at a level of $p<0.05$. All statistical analyses were performed using the statistical program R (R Development Core Team, 2012).

\subsection{Results and Discussion}

\subsubsection{Trees}

Analysis of variance indicated significant differences for all main effects. Brown sandstone treatments had a significantly higher mean tree volume index $\left(5,333 \mathrm{~cm}^{3}\right)$ than gray sandstone $\left(3,031 \mathrm{~cm}^{3}\right)$ (Table 3-4). The mean tree volume index on mulched treatments was significantly higher at $6,187 \mathrm{~cm}^{3}$ than non-mulched treatments at 4,194 $\mathrm{cm}^{3}$ (Figure 3-2). Treatments which received a hydroseed application had a mean tree volume index of $5,809 \mathrm{~cm}^{3}$ while trees grown on non-hydroseeded treatments averaged $3,403 \mathrm{~cm}^{3}$. 
Table 3-4. Treatment effects for volume and survival after six growing seasons in eight soil treatments at Arch Coal's Birch River mine in Webster County, WV.

\begin{tabular}{|c|c|c|c|c|c|c|}
\hline & & Survival & $\begin{array}{l}\text { Volume } \\
\text { Index } 1^{\ddagger}\end{array}$ & SE & $\begin{array}{l}\text { Volume } \\
\text { Index } 2^{€}\end{array}$ & $\begin{array}{c}\text { Volume } \\
\text { Difference }\end{array}$ \\
\hline \multirow[t]{3}{*}{ Substrate } & & $\%$ & $\mathrm{~cm}^{3}$ & & $\mathrm{~cm}^{3}$ & $\%$ \\
\hline & Brown & 83 & $5333^{a}{ }^{\mp}$ & 480 & $4670^{\mathrm{a}}$ & 18 \\
\hline & Gray & 72 & $3031^{\mathrm{b}}$ & 524 & $2553^{b}$ & 29 \\
\hline \multicolumn{7}{|l|}{ Mulch } \\
\hline & Mulch & 81 & $6187^{\mathrm{a}}$ & 825 & $5219^{\mathrm{a}}$ & 18 \\
\hline & No mulch & 78 & $4194^{b}$ & 420 & $3701^{b}$ & 19 \\
\hline \multicolumn{7}{|c|}{ Hydroseed } \\
\hline & Hydroseed & 82 & $5809^{a}$ & 608 & $5015^{\mathrm{a}}$ & 22 \\
\hline & No hydroseed & 76 & $3403^{b}$ & 402 & $3001^{b}$ & 16 \\
\hline \multicolumn{7}{|l|}{ Interaction } \\
\hline & $\mathrm{B} \S$ & 87 & $3316^{\mathrm{ab}}$ & 491 & $2864^{\mathrm{ab}}$ & 17 \\
\hline & $\mathrm{BM}$ & 100 & $5563^{\mathrm{a}}$ & 1431 & $4952^{\mathrm{a}}$ & 15 \\
\hline & $\mathrm{BMH}$ & 77 & $7717^{\mathrm{a}}$ & 1957 & $6102^{a}$ & 21 \\
\hline & $\mathrm{BH}$ & 76 & $6243^{a}$ & 794 & $5557^{\mathrm{a}}$ & 19 \\
\hline & $\mathrm{G}$ & 63 & $818^{\mathrm{c}}$ & 261 & $733^{b c}$ & 16 \\
\hline & GM & 70 & $4897^{\mathrm{a}}$ & 1210 & $4377^{\mathrm{a}}$ & 14 \\
\hline & GMH & 100 & $7334^{\mathrm{a}}$ & 2116 & $5827^{\mathrm{a}}$ & 24 \\
\hline & $\mathrm{GH}$ & 100 & $1663^{\mathrm{bc}}$ & 569 & $1335^{\mathrm{c}}$ & 32 \\
\hline \multicolumn{7}{|l|}{ Species } \\
\hline & Black cherry & 86 & $6971^{a}$ & 1621 & $6112^{a}$ & 16 \\
\hline & Black locust & 100 & $6620^{\mathrm{ab}}$ & 713 & $5849^{\mathrm{ab}}$ & 18 \\
\hline & Redbud & 33 & $2789^{\mathrm{abc}}$ & 1356 & $2126^{\mathrm{abc}}$ & 21 \\
\hline & Red oak & 64 & $1949^{\mathrm{ab}}$ & 270 & $1637^{\mathrm{ab}}$ & 18 \\
\hline & Sugar maple & 52 & $417^{\mathrm{c}}$ & 84 & $334^{\mathrm{c}}$ & 29 \\
\hline & Sycamore & 69 & $4957^{\mathrm{a}}$ & 1379 & $4056^{\mathrm{ab}}$ & 20 \\
\hline & Tulip-poplar & 86 & $5962^{\mathrm{ab}}$ & 1908 & $4941^{\mathrm{ab}}$ & 22 \\
\hline & White ash & 75 & $1897^{\mathrm{abc}}$ & 347 & $1536^{\mathrm{ab}}$ & 22 \\
\hline & White oak & 75 & $1495^{\mathrm{bc}}$ & 265 & $1266^{\mathrm{bc}}$ & 23 \\
\hline & White pine & 78 & $2762^{\mathrm{ab}}$ & 441 & $2337^{\mathrm{ab}}$ & 13 \\
\hline
\end{tabular}

$\S$ see Table 3-3 for treatment descriptions.

$¥$ diameter measured at $2.5 \mathrm{~cm}$ above soil surface.

${ }^{€}$ diameter measured at $10 \mathrm{~cm}$ above soil surface.

$\dagger$ percent difference between volume index 1 and volume index 2 .

${ }^{\mathrm{I}}$ means for each treatment within column group with the same letter are not significantly different at $\mathrm{p}$ $<0.05$. 


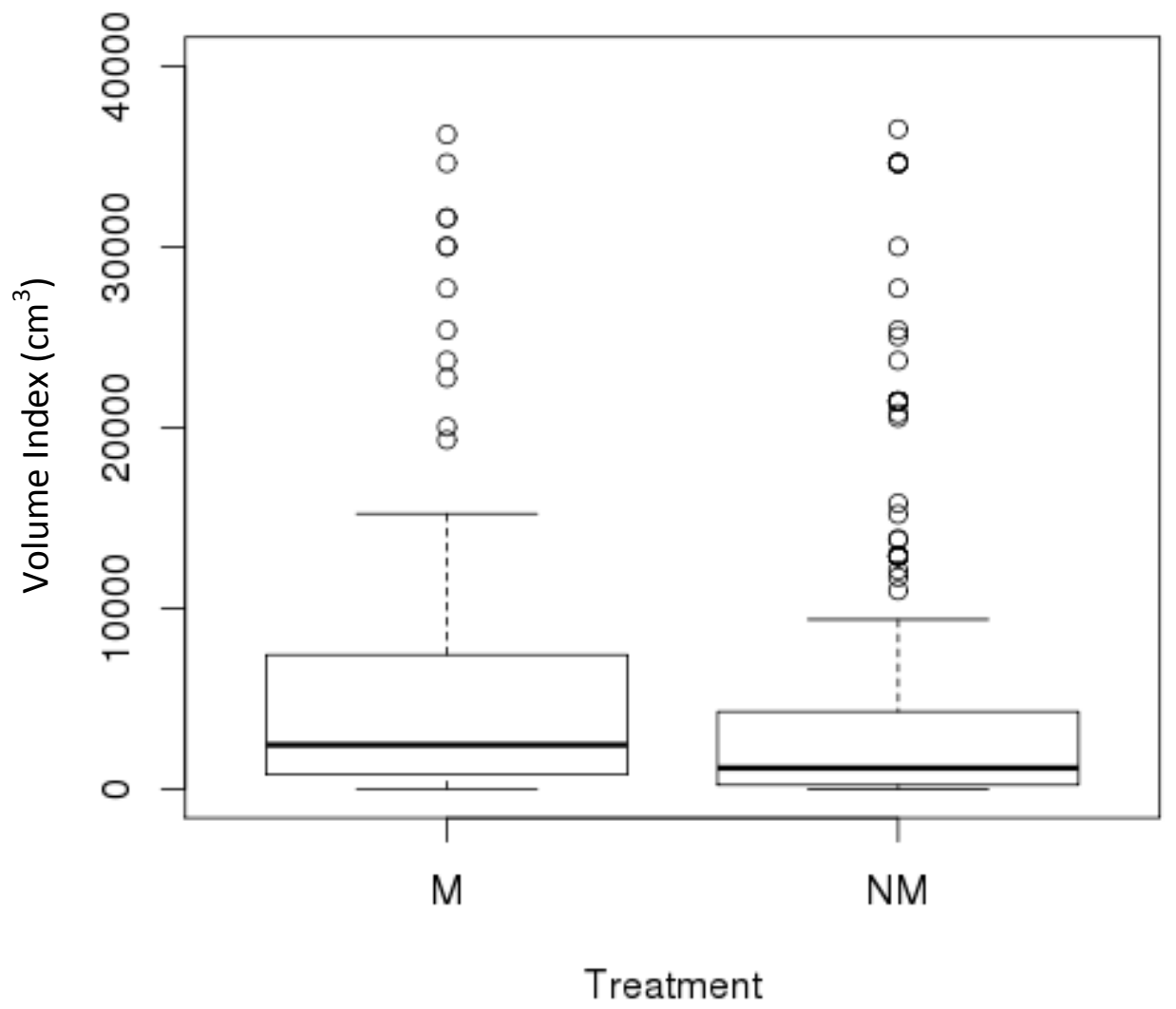

Figure 3-2. Boxplot of tree volume index on mulched (M) and non-mulched (NM) treatments at Arch Coal's Birch River mine in Webster County, WV. Black lines within boxes indicate the mean volume index, boxes indicate the upper and lower quartile, and bars outside the box give $99 \%$ of all values (three standard deviations) and circles represent outliers.

Similar studies comparing the two types of sandstone reported that trees grown on weathered brown sandstone supported faster growth and produced greater tree volumes than trees grown on unweathered gray sandstone (Angel et al., 2008; Emerson et al., 2009). Angel et al. (2006) found that mine spoils amended with bark mulch produced greater tree height growth than trees grown on non-amended mine spoils; on average, trees on bark mulch were $50 \mathrm{~cm}$ taller than trees with no soil amendment. Currently on mulched treatments, tree growth was not significantly different between sandstone substrates and tree volume indices on brown-mulch 
(BM) treatments were very similar to those on gray-mulch (GM) treatments (Table 3-4). It is possible that the young trees were predominantly relying on the mulch as the growth medium. Based on other studies, the type of sandstone will eventually influence tree growth once the roots become more established and reach into the soil below the bark mulch.

Aggressive herbaceous vegetation has been shown to out-compete tree seedlings for nutrients, water, and solar energy when seeded at high densities (Fields-Johnson et al., 2010). However, when tree-compatible species such as birdsfoot trefoil (Lotus corniculatus L.) and ladino clover (Trifolium repens L.) are seeded, they can benefit tree seedling growth by reducing evapotranspiration, shading the soil surface, and increasing the soil water holding capacity through adding organic matter to the soil via root decay (Franklin et al., 2012). Vogel (1973) reported that tree growth on legume-dominated plots exceeded tree growth on grass-dominated plots in Kentucky after the fourth growing season. After four years, Virginia pine (Pinus virginiana Mill.) grown on legume-dominated plots was, on average, $30 \mathrm{~cm}$ taller than Virginia pine grown on grass-dominated plots.

The average tree survival was slightly higher on brown sandstone treatments $(83 \%)$ compared with gray sandstone treatments (72\%) (Table 3-4). Average tree survival on mulched treatments was $81 \%$ compared to $78 \%$ on non-mulched treatments. Average tree survival on hydroseeded treatments was $82 \%$ while non-hydroseeded treatments averaged $76 \%$. Black locust (Robinia pseudoacacia L.) had the highest survival rate at $100 \%$ followed by black cherry (Prunus serotina Ehrh.) and tulip-poplar (Liriodendron tulipifera L.) which both had the second highest survival rates at 86\% (Table 3-4). Sugar maple (Acer saccharum Marsh.) and Eastern redbud (Cercis canadensis L.) had the lowest survival rates at 52\% and 33\%, respectively (Table 3-4). In general, most treatments (substrate, mulch, and hydroseeding) did not appear to affect overall tree survival with the exception of the gray sandstone only $(G)$ treatment which had a survival of only $63 \%$. One explanation for this result is that the low percentage of fines and lack of organic matter decreased the soil's ability to hold plant-available water and nutrients (Miller et al., 2010). 
For treatment interactions, the gray sandstone only (G) and gray sandstone with hydroseeding $(\mathrm{GH})$ treatments displayed the poorest overall tree volume indices, $818 \mathrm{~cm}^{3}$ and $1,663 \mathrm{~cm}^{3}$, respectively (Table 3-4). Mulch application on gray sandstone yielded tree volume indices that were statistically similar to tree volume indices measured on all brown sandstone treatment combinations at $\mathrm{p}<0.05$ (Table3-4). This trend was evident in the 2011 growing season and continues to hold true for the 2012 growing season (Table 3-5 and Figure 3-3). Several studies have shown that the addition of organic mulch or topsoil greatly improved tree height even on unfavorable mine soil substitutes (Angel et al., 2006; Showalter et al., 2010; Kost et al., 1998). The low percentage of fines on the $\mathrm{G}$ and $\mathrm{GH}$ treatments likely reduced the plantavailable water holding capacity and negatively affected tree growth. The mulch amendment to the gray sandstone could have increased the water holding capacity as well as provided plantavailable nutrients which would ultimately have a positive influence on tree growth. The mulch application did not increase tree growth on brown sandstone as dramatically as on gray sandstone. This may be due to the brown sandstone already having a greater percent fines and some organic matter which limited some of the positive effects of the mulch on this substrate compared to the coarse-textured and no organic matter containing gray sandstone.

Table 3-5. Mean tree volume index ${ }^{¥}$ for $2008-2012$ growing seasons in eight soil treatments at Arch Coal's Birch River mine in Webster County, WV. 2008 to 2011 data are from DeLong (2010) and Thomas (2012).

\begin{tabular}{|c|c|c|c|c|c|c|c|c|}
\hline \multirow[b]{2}{*}{ Year } & \multicolumn{8}{|c|}{ Treatments $\S$} \\
\hline & B & $\mathbf{B M}$ & BMH & BH & $\mathbf{G}$ & GM & GMH & GH \\
\hline 2008 & $43^{\mathrm{a}+}$ & $36^{\mathrm{a}}$ & $27^{\mathrm{a}}$ & $50^{\mathrm{a}}$ & $27^{\mathrm{a}}$ & $48^{\mathrm{a}}$ & $14^{\mathrm{a}}$ & $17^{\mathrm{a}}$ \\
\hline 2009 & $218^{\mathrm{ab}}$ & $299^{a}$ & $507^{\mathrm{a}}$ & $293^{\mathrm{abc}}$ & $30^{\mathrm{c}}$ & $218^{\mathrm{ab}}$ & $63^{\mathrm{bc}}$ & $40^{\mathrm{c}}$ \\
\hline 2010 & $582^{\mathrm{ab}}$ & $1047^{\mathrm{a}}$ & $705^{\mathrm{abc}}$ & $712^{a}$ & $72^{\mathrm{d}}$ & $765^{\mathrm{ab}}$ & $182^{\mathrm{bcd}}$ & $229^{\mathrm{cd}}$ \\
\hline 2011 & $2086^{\mathrm{a}}$ & $2929^{a}$ & $2044^{\mathrm{a}}$ & $1687^{\mathrm{a}}$ & $248^{\mathrm{b}}$ & $1852^{\mathrm{a}}$ & $1077^{\mathrm{a}}$ & $163^{\mathrm{b}}$ \\
\hline 2012 & $3316^{\mathrm{ab}}$ & $5563^{\mathrm{a}}$ & $7717^{\mathrm{a}}$ & $6243^{\mathrm{a}}$ & $818^{c}$ & $4897^{\mathrm{a}}$ & $7334^{\mathrm{a}}$ & $1663^{b c}$ \\
\hline
\end{tabular}

$\S$ see Table 3-3 for treatment descriptions

$¥$ diameter measured at 2.5 -cm above soil surface

${ }^{\mathrm{I}}$ means for each volume index within rows (years) with the same letter are not significantly different at $\mathrm{p}<0.05$. 


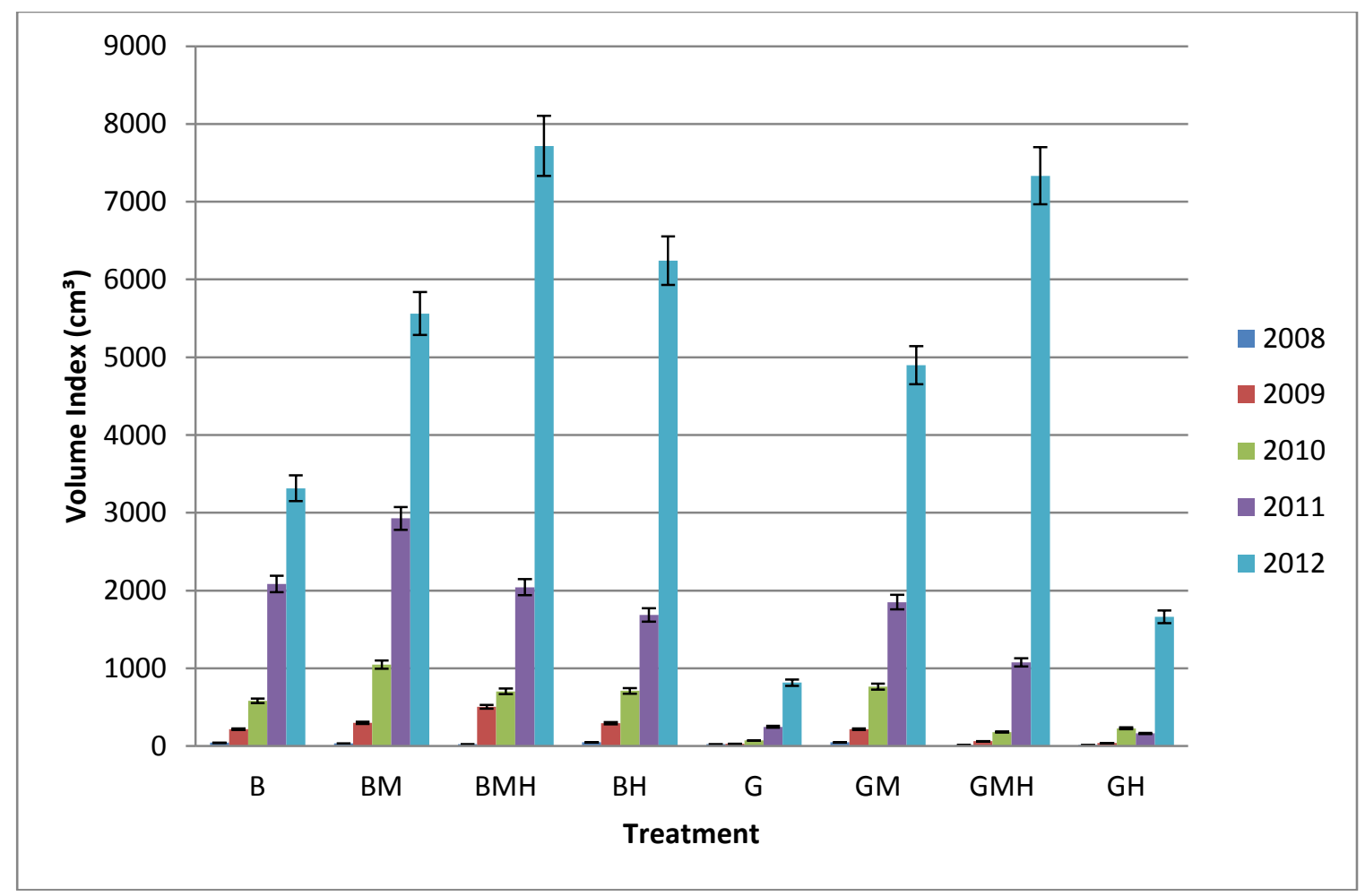

Figure 3-3. Mean tree volume index 1 with error bars at $5 \%$ after six growing seasons for eight treatments at Arch Coal's Birch River mine in Webster County, WV in 2012.

For individual tree species, black cherry had the highest average tree volume index at $6,971 \mathrm{~cm}^{3}$ (Table 3-6). Black cherry had a wide range of values across treatments with the highest mean volume index on the GMH treatment (Figure 3-4). Overall, this species seemed to perform well on mulched treatments and had a healthy appearance. Black cherry is an earlysuccessional species that grows on a wide range of sites and has the potential to establish rapidly on disturbed sites (Hicks Jr., 1998). Although black cherry can tolerate a variety of soil conditions it prefers deep, well-drained soils and, apparently, preferred the mulch treatment. 


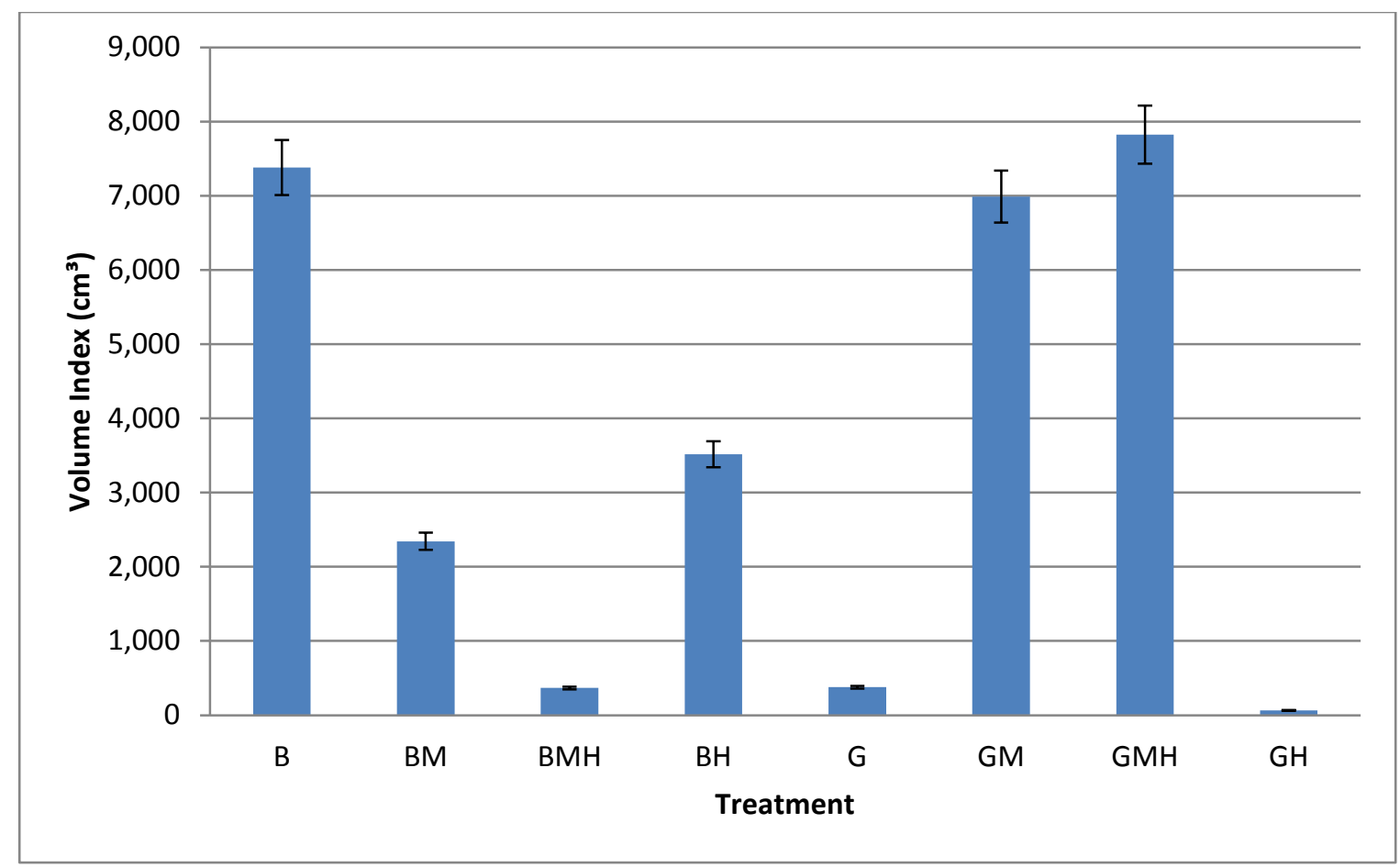

Figure 3-4. Mean tree volume index 1 with error bars at 5\% for black cherry in 2012 on eight treatments at Arch Coal's Birch River mine in Webster County, WV.

Black locust had the second highest mean volume index at $6,620 \mathrm{~cm}^{3}$ (Table 3-4). Figure 3-5 illustrates the difference in volume indices across all treatments. The GMH treatment displayed the lowest mean volume index at $121 \mathrm{~cm}^{3}$, however only 2 specimens were measured on this treatment (Tables 3-6 and 3-7). The BH treatment demonstrated the highest mean volume index at 9,250 $\mathrm{cm}^{3}$ and had the largest number of black locust sampled, 94 (Tables 3-6 and 3-7). To date, black locust has been the only tree species in this study to voluntarily establish new tree seedlings therefore increasing the total number of black locust measured each year. Black locust is another early-successional tree that has repeatedly performed well on mined lands (Emerson et al., 2009; Miller et al., 2010). Its excellent performance on mined land is most likely due to its ability to grow on a variety of soil types and its tolerance to a $\mathrm{pH}$ range of 4.6 to 8.2 (Huntley, 1990). Black locust is ecologically important to forest ecosystems because it provides shelter for many animals as well as food for mammals and birds (Larkin et al., 2008). It also serves as a nitrogen-fixer which can be beneficial to drastically disturbed lands with marginally available nutrients. 


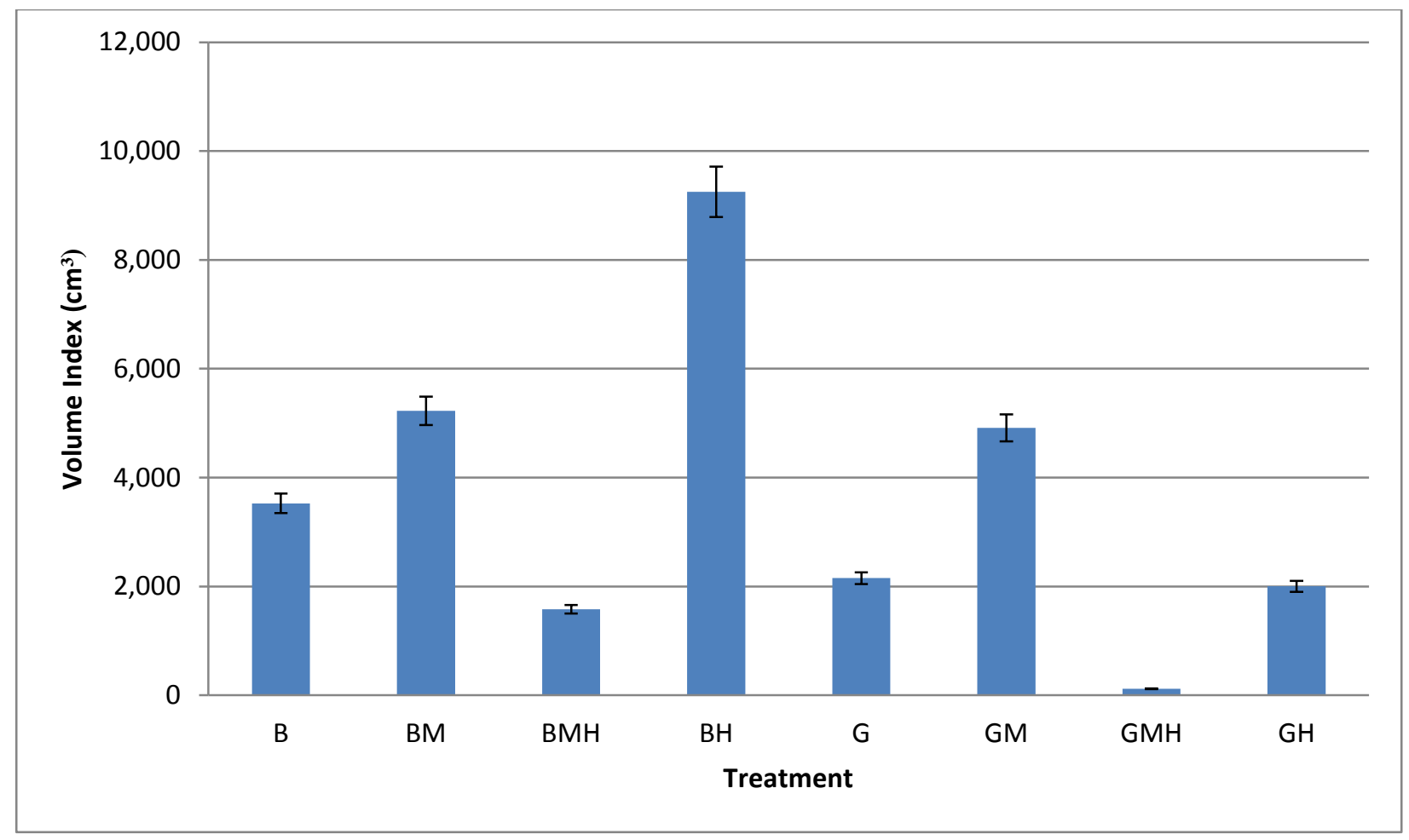

Figure 3-5. Mean tree volume index 1 with error bars at 5\% for black locust in 2012 on eight treatments at Arch Coal's Birch River mine in Webster County, WV.

Tulip-poplar had the second highest survival rate at $86 \%$ and a mean volume index of $5,962 \mathrm{~cm}^{3}$ (Table 3-4). While tulip-poplar was persistent on the G and GH treatments it still demonstrated a low mean volume index, $605 \mathrm{~cm}^{3}$ and $149 \mathrm{~cm}^{3}$, respectively (Table 3-6 and Figure 3-6). Tulip-poplar is a major tree species found in the southern Appalachian forests (Lux and Cumming, 1999). While the tulip-poplar tree is often planted for reforestation purposes due to its rapid growth and commercial importance, it performs best on moderately moist, deep, welldrained, loose textured soils and tolerates a pH range of 4.5 to 7.5 (USDA NRCS, 2012). One explanation for the poor growth on the $\mathrm{G}$ and $\mathrm{GH}$ treatments could be due to the low percentage of fines which would have reduced the amount of plant-available water (Table 3-8). 


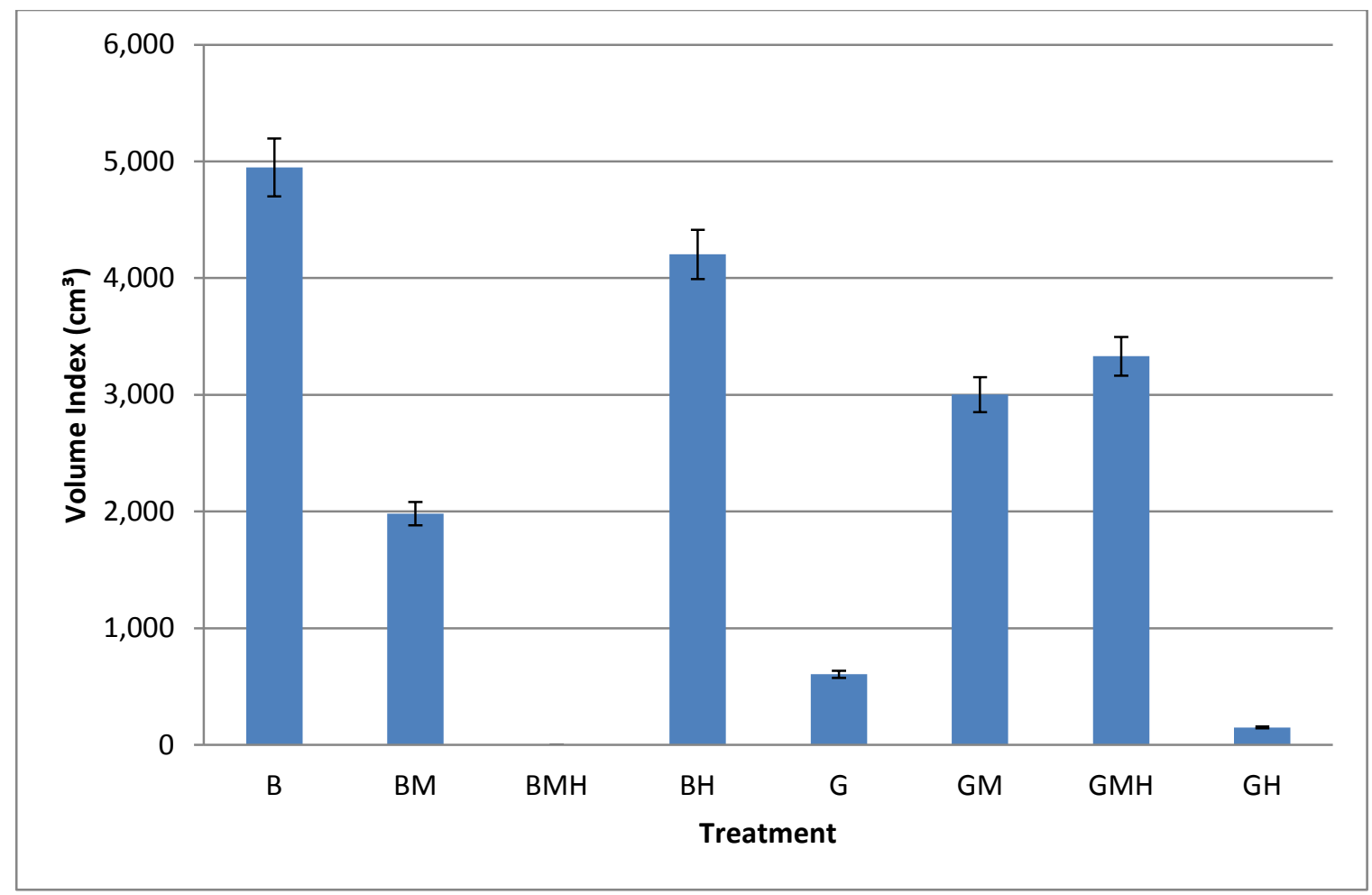

Figure 3-6. Mean tree volume index 1 with error bars at 5\% for tulip-poplar in 2012 on seven treatments at Arch Coal's Birch River mine in Webster County, WV. No specimens were sampled on the BMH treatment.

Eastern redbud had the lowest survival rate of all species at 33\%. Only three specimens were measured; one each on B, BM, and GM treatments (Figure 3-7). While survival was low, mean volume index was reasonable at 2,789 $\mathrm{cm}^{3}$. Miller et al. (2010) reported that redbud experienced a low survival rate of $58 \%$ on gray sandstone and an average height of $35 \mathrm{~cm}$ after two growing seasons. Eastern redbud is an understory tree found on moist, loam or sandy soils and can tolerate a wide range of $\mathrm{pH}$ but prefers a $\mathrm{pH}$ of 7.5 or higher (USDA NRCS, 2012). Like black locust, Eastern redbud is ecologically important to forest ecosystems as a food source for many mammals and birds and it serves as a nitrogen-fixer which can be beneficial to drastically disturbed lands with marginally available nutrients (USDA NRCS, 2012). 


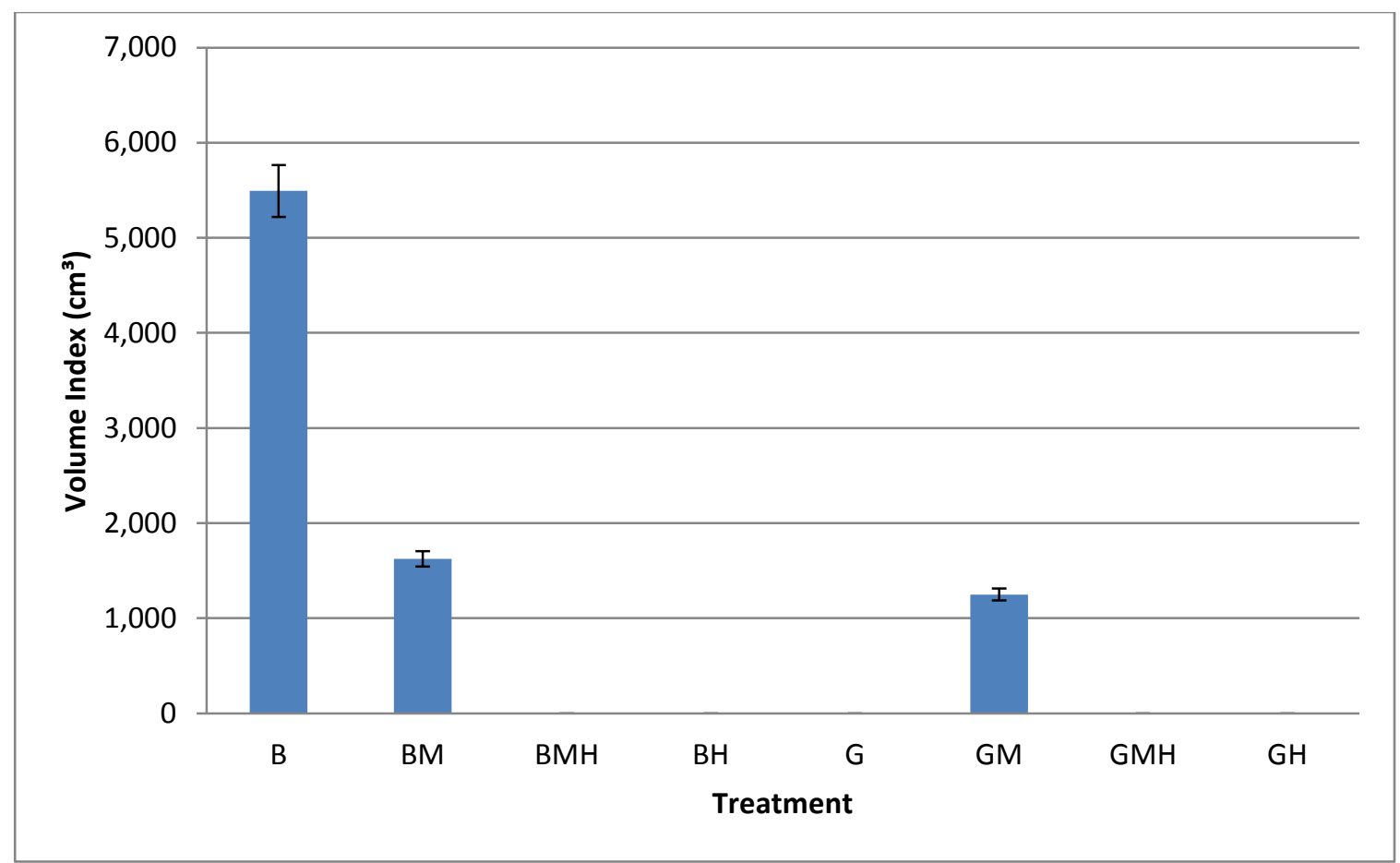

Figure 3-7. Mean tree volume index 1 with error bars at 5\% for redbud in 2012 on three treatments at Arch Coal's Birch River mine in Webster County, WV. No specimens were sampled on the BMH, BH, G, GMH, and GH treatments.

Sugar maple displayed the poorest growth of all species with an average volume index of $417 \mathrm{~cm}^{3}$. Sugar maple has consistently exhibited poor growth across all treatment combinations in this study (Figure 3-8). Miller et al. (2010) reported that sugar maple grew poorly on both brown sandstone and gray sandstone mine spoils with little height difference between trees grown on brown and gray sandstone. Normally, forest ecosystems dominated by sugar maple have a high nitrogen availability and high nitrogen mineralization rate which suggests that nitrogen deficiencies would limit sugar maple growth on marginal sites (Pastor et al., 1982; Whitney, 1997). While sugar maple trees can tolerate a $\mathrm{pH}$ range of 3.7 to 7.3 , they grow best on deep, moist, well-drained, fine-textured soils with pH 5.5 to 7.3 (Godman, 1965). Nowak, 1996, reported that on marginal sites, sugar maple typically has a slow growth rate and deteriorates at an early age. 


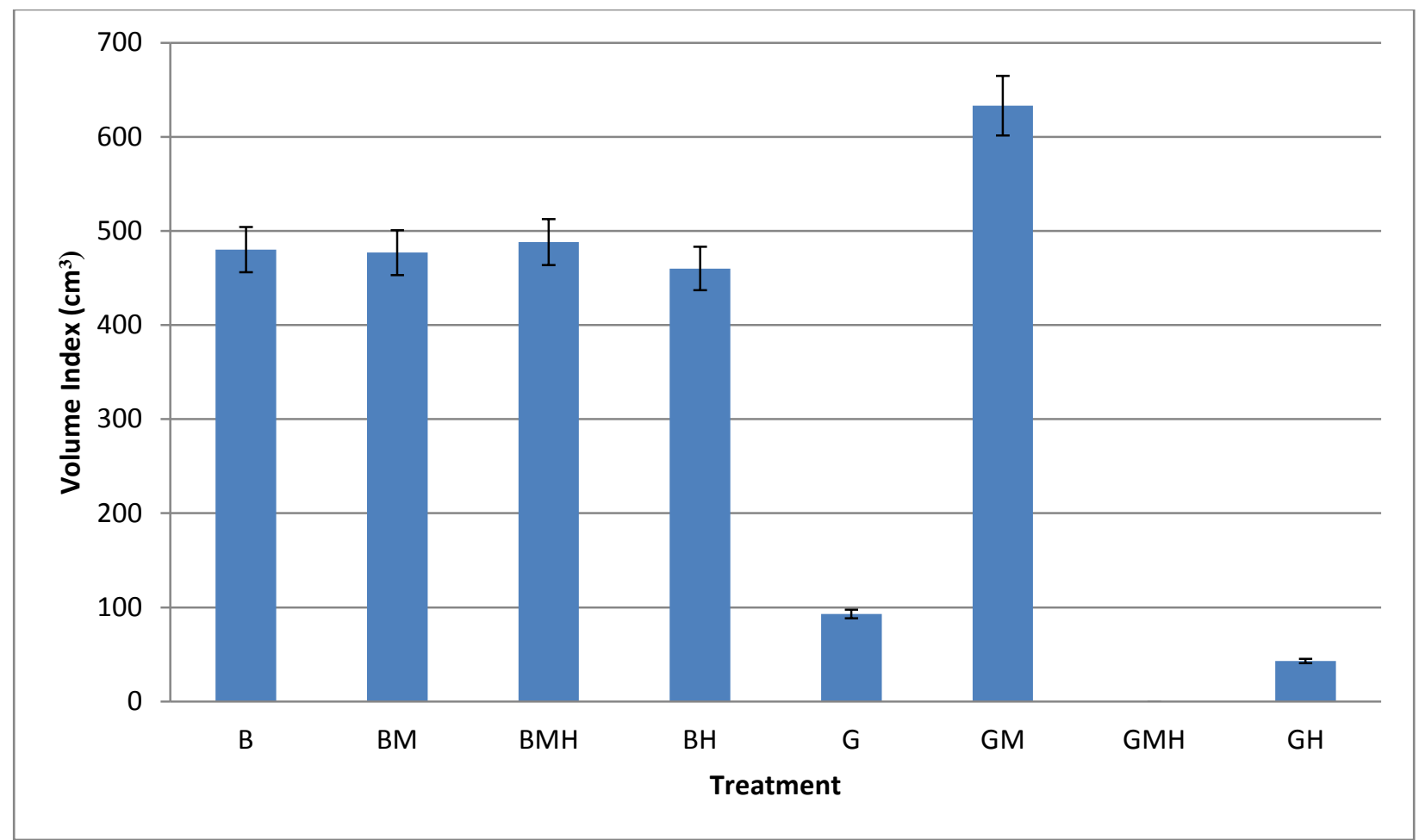

Figure 3-8. Mean tree volume index 1 with error bars at $5 \%$ for sugar maple in 2012 on seven treatments at Arch Coal's Birch River mine in Webster County, WV. No specimens were sampled on the GMH treatment.

All tree species showed a wide range of volume indices among treatment combinations. Black locust had the largest difference for average volume index, which ranged from 121 to $9,250 \mathrm{~cm}^{3}$ across treatments (Table 3-6). Sugar maple had the smallest difference of average tree volume indices ranging from 43 to $633 \mathrm{~cm}^{3}$ (Table 3-6). Due to the limitations of planting strategy, tree species were unevenly distributed among treatments. This uneven distribution could have misrepresented tree growth in specific treatment combinations because some trees grew larger than others (Table 3-7). If large-growing trees were planted more and overrepresented in a particular treatment combination, the average volume index for that particular treatment combination may have been significantly higher than another simply because it had large-growing trees within its boundaries. For example, black locust, one of the largest growing trees, had much higher numbers planted in the brown treatment (n from 11 to 94), while fewer locust trees were found in gray treatments (except for gray-hydroseed) (Table 3-7). A better comparison to show the effects of tree growth across treatment combinations may be to look at 
species with similar numbers across treatments like black cherry and red oak. With black cherry, clearly all treatments with brown sandstone $(\mathrm{B}, \mathrm{BM}, \mathrm{BMH}$, and $\mathrm{BH})$ and gray-mulch $(\mathrm{GM})$ and gray-mulch-hydroseed (GMH) showed the greatest volume index. For red oak, similar treatments gave similar volume indices. With white pine, all treatments except gray sandstone alone gave good tree growth.

Table 3-6. Mean tree volume index ${ }^{¥}$ of each tree species in 2012 after six growing seasons in eight soil treatments at Arch Coal's Birch River mine in Webster County, WV.

\begin{tabular}{lccccccccc}
\hline & \multicolumn{8}{c}{ Treatments $\$$} \\
\cline { 2 - 8 } Species & B & BM & BMH & BH & G & GM & GMH & GH & AVG. \\
\hline Black cherry & 7,380 & 2,344 & 366 & 3,516 & 377 & 6,988 & 7,825 & 64 & 6,971 \\
Black locust & 3,528 & 5,228 & 1,583 & 9,250 & 2,155 & 4,913 & 121 & 2,003 & 6,620 \\
Redbud & 5,492 & 1,625 & --- & --- & --- & 1,249 & --- & --- & 2,789 \\
Red oak & 3,612 & 2,440 & 1,594 & 2,020 & 361 & 3,503 & 726 & 16 & 1,949 \\
Sugar maple & 480 & 477 & 488 & 460 & 93 & 633 & --- & 43 & 417 \\
Sycamore & 2,674 & --- & 3,828 & 2,412 & 8,784 & --- & 1,789 & 208 & 4,957 \\
Tulip-poplar & 4,948 & 1,981 & --- & 4,203 & 605 & 3,001 & 3,330 & 149 & 5,962 \\
White ash & 2,508 & 3,904 & 790 & 1,121 & 932 & 2,056 & --- & 1,262 & 1,897 \\
White oak & 2,180 & 3,749 & 1,094 & 1,340 & 114 & 1,067 & 3,104 & 111 & 1,495 \\
White pine & 4,073 & 1,931 & 6,896 & 2,424 & 629 & 4,358 & 4,586 & 5,372 & 2,762 \\
\hline
\end{tabular}

${ }^{\ddagger}$ diameter measured at $2.5 \mathrm{~cm}$ above soil surface.

$\S$ see Table 3-3 for treatment descriptions. 
Table 3-7. Distribution of tree species in 2012 after six growing seasons in eight soil treatments at Arch Coal's Birch River mine in Webster County, WV.

\begin{tabular}{|c|c|c|c|c|c|c|c|c|c|}
\hline & \multicolumn{9}{|c|}{ Treatments $\S$} \\
\hline & B & $\mathbf{B M}$ & BMH & BH & $\mathbf{G}$ & GM & GMH & GH & Total \\
\hline Total Area $\left(\mathrm{m}^{2}\right)$ & 6,025 & 1,100 & 1,100 & 7,525 & 6,525 & 1,100 & 1,100 & 3,525 & 28,000 \\
\hline $\begin{array}{l}\text { Area Sampled } \\
(\%)\end{array}$ & 11 & 12 & 7 & 10 & 11 & 12 & 7 & 10 & 10 \\
\hline \multicolumn{10}{|l|}{ Species } \\
\hline Black cherry & 7 & 3 & 1 & 7 & 3 & 4 & 6 & 1 & 32 \\
\hline Black locust & 41 & 22 & 11 & 94 & 4 & 7 & 2 & 22 & 203 \\
\hline Redbud & 1 & 1 & --- & --- & --- & 1 & --- & --- & 3 \\
\hline Red oak & 6 & 1 & 2 & 15 & 7 & 3 & 2 & 1 & 37 \\
\hline Sugar maple & 11 & 1 & 1 & 8 & 2 & 1 & --- & 2 & 26 \\
\hline Sycamore & 8 & --- & 1 & 4 & 1 & --- & 3 & 1 & 18 \\
\hline Tulip-poplar & 3 & 1 & --- & 6 & 7 & 1 & 5 & 4 & 24 \\
\hline White ash & 11 & 2 & 1 & 7 & 4 & 6 & --- & 2 & 33 \\
\hline White oak & 6 & 3 & 2 & 13 & 6 & 1 & 3 & 3 & 37 \\
\hline White pine & 8 & 6 & 2 & 7 & 11 & 2 & 2 & 2 & 40 \\
\hline Total & 102 & 40 & 21 & 161 & 45 & 26 & 23 & 35 & 453 \\
\hline
\end{tabular}

$\S$ see Table 3-3 for treatment descriptions.

\subsubsection{Soil}

The $\mathrm{pH}$ values for non-mulched brown sandstone treatments were the lowest of all treatment combinations, 5.0 for $\mathrm{B}$ and 5.4 for $\mathrm{BH}$ (Table 3-8). All gray sandstone treatment combinations and the BM treatment were statistically similar at the level $\mathrm{p}<0.05$ and ranged from 6.9 to 8.0 (Table 3-8). The $\mathrm{BMH}$ treatment had the lowest $\mathrm{pH}$ (6.3) of all mulched treatments and was statistically similar to the non-mulched brown sandstone treatments (Table 38).

The mean $\mathrm{pH}$ ranges for non-mulched brown sandstone treatments in this study fell within the typical range for weathered sandstones ( $\mathrm{pH} 4.5$ to 5.5) while the non-mulched gray sandstone treatments ranged from slightly below to well within the typical range for unweathered sandstones (pH 7.5 to 8.0) (Emerson et al., 2009; Haering et al., 2004). Average pH values have fluctuated slightly over the years since this study began in 2008. Mulched treatments have continually exhibited elevated $\mathrm{pH}$ values because of the presence of limestone gravel in the bark mulch. Limestone gravel is commonly added as an aggregate on log landings and becomes incorporated into the mulch as it is weathered and broken by traffic at the sawmill. 
Percent fines across treatment combinations were not significantly different except for gray sandstone with hydroseeding $(\mathrm{GH})$. Average percent fines for $\mathrm{GH}$ were $25 \%$ while percent fines ranged from 40 to $63 \%$ for all other treatment combinations (Table 3-8). While there was little statistical difference in percent fines among treatments, the non-mulched gray sandstone treatments continued to have a lower percentage of percent fines than non-mulched brown sandstone treatments over the course of this study. Miller et al. (2010) found that gray sandstone rocks exhibited a higher durability in a slake-durability test and were highly resistant to weathering during the freeze-thaw test. Zipper et al. (2011) reported that soils derived from gray sandstone would continue to have coarse fragments as they age. High percentages of coarse fragments have shown reduced water holding capacities which can negatively influence a site's productivity (Rodrigue and Burger, 2004).

The electrical conductivity (EC) values for 2012 were all low. The average EC ranged from $0.06 \mathrm{dS} \mathrm{m}^{-1}$ to $0.37 \mathrm{dS} \mathrm{m}^{-1}$ (Table 3-8). Treatment combinations with mulch application had significantly higher EC than treatments without mulch application $\left(0.18 \mathrm{dS} \mathrm{m}^{-1}\right.$ to $\left.0.37 \mathrm{dS} \mathrm{m}^{-1}\right)$ (Table 3-8). These results are consistent with previous years' findings (Table 3-8). All EC values in 2012 were $<0.40 \mathrm{dS} \mathrm{m}^{-1}$ which is still well below the level at which sensitive species such as sugar maple and white pine experience reduced tree growth and survival; EC values $>1-3 \mathrm{dS} \mathrm{m}^{-1}$ can have detrimental effects on plant growth (McFee et al., 1981; Whiting et al., 2010). 
Table 3-8. 2008-2012 soil properties of samples from eight soil treatments at Arch Coal's Birch River mine in Webster County, WV. 2008 and 2009 data are from DeLong (2010). 2010 and 2011 data are from Thomas (2012).

\begin{tabular}{|c|c|c|c|c|c|c|c|c|}
\hline \multirow[b]{2}{*}{ Properties } & \multicolumn{8}{|c|}{ Treatments $\S$} \\
\hline & B & BM & BMH & BH & G & GM & GMH & GH \\
\hline $\mathrm{pH}$ & & $-\cdots$ & & & - -su--. & - & - & ----- \\
\hline 2008 & $4.7^{\mathrm{b} \mathrm{I}}$ & $7.1^{\mathrm{a}}$ & $8.0^{\mathrm{a}}$ & $4.8^{\mathrm{b}}$ & $7.9^{\mathrm{a}}$ & $7.0^{\mathrm{a}}$ & $6.9^{\mathrm{a}}$ & $7.3^{\mathrm{a}}$ \\
\hline 2009 & $4.8^{\mathrm{b}}$ & $7.5^{\mathrm{a}}$ & $7.7^{\mathrm{a}}$ & $5.4^{\mathrm{b}}$ & $7.8^{\mathrm{a}}$ & $7.5^{\mathrm{a}}$ & $7.0^{\mathrm{a}}$ & $7.7^{\mathrm{a}}$ \\
\hline 2010 & $5.0^{\mathrm{b}}$ & $6.7^{\mathrm{ab}}$ & $7.6^{\mathrm{a}}$ & $5.3^{\mathrm{b}}$ & $7.4^{\mathrm{a}}$ & $7.6^{\mathrm{a}}$ & $7.6^{\mathrm{a}}$ & $7.1^{\mathrm{a}}$ \\
\hline 2011 & $5.1^{\mathrm{b}}$ & $7.7^{\mathrm{a}}$ & $7.6^{\mathrm{a}}$ & $5.4^{\mathrm{b}}$ & $7.5^{\mathrm{a}}$ & $7.7^{\mathrm{a}}$ & $7.7^{\mathrm{a}}$ & $7.3^{\mathrm{a}}$ \\
\hline 2012 & $5.0^{\mathrm{c}}$ & $7.2^{\mathrm{ab}}$ & $6.4^{\mathrm{bc}}$ & $5.4^{\mathrm{c}}$ & $7.0^{\mathrm{ab}}$ & $7.8^{\mathrm{ab}}$ & $8.0^{\mathrm{a}}$ & $7.7^{\mathrm{ab}}$ \\
\hline $\mathrm{EC}$ & & & & & $\mathrm{dS} \mathrm{m}^{-1}$ & & & \\
\hline 2008 & $0.12^{\mathrm{bc}}$ & $0.28^{\mathrm{ab}}$ & $0.39^{\mathrm{a}}$ & $0.06^{\mathrm{c}}$ & $0.12^{\mathrm{bc}}$ & $0.28^{\mathrm{ab}}$ & $0.40^{\mathrm{a}}$ & $0.12^{\mathrm{bc}}$ \\
\hline 2009 & $0.05^{\mathrm{b}}$ & $0.31^{\mathrm{a}}$ & $0.30^{\mathrm{a}}$ & $0.07^{\mathrm{b}}$ & $0.08^{\mathrm{b}}$ & $0.33^{\mathrm{a}}$ & $0.29^{\mathrm{a}}$ & $0.11^{\mathrm{b}}$ \\
\hline 2010 & $0.08^{c}$ & $0.35^{\mathrm{ab}}$ & $0.42^{\mathrm{a}}$ & $0.08^{\mathrm{c}}$ & $0.09^{c}$ & $0.49^{\mathrm{a}}$ & $0.53^{\mathrm{a}}$ & $0.16^{\mathrm{bc}}$ \\
\hline 2011 & $0.04^{\mathrm{a}}$ & $0.38^{\mathrm{b}}$ & $0.34^{\mathrm{b}}$ & $0.04^{\mathrm{a}}$ & $0.05^{\mathrm{a}}$ & $0.35^{\mathrm{b}}$ & $0.48^{\mathrm{b}}$ & $0.04^{\mathrm{a}}$ \\
\hline 2012 & $0.06^{\mathrm{c}}$ & $0.28^{\mathrm{ab}}$ & $0.18^{\mathrm{abc}}$ & $0.07^{b c}$ & $0.11^{\mathrm{bc}}$ & $0.37^{\mathrm{a}}$ & $0.36^{\mathrm{a}}$ & $0.09^{b c}$ \\
\hline Fines & & & & & $--\%$ & & & \\
\hline 2008 & $58^{\mathrm{a}}$ & $25^{\mathrm{b}}$ & $27^{\mathrm{b}}$ & $47^{\mathrm{ab}}$ & $42^{\mathrm{ab}}$ & $34^{\mathrm{ab}}$ & $32^{\mathrm{b}}$ & $34^{\mathrm{ab}}$ \\
\hline 2009 & $53^{a}$ & $37^{\mathrm{ab}}$ & $41^{\mathrm{ab}}$ & $49^{\mathrm{ab}}$ & $41^{\mathrm{ab}}$ & $42^{\mathrm{ab}}$ & $35^{\mathrm{b}}$ & $37^{\mathrm{ab}}$ \\
\hline 2010 & $38^{\mathrm{a}}$ & $33^{\mathrm{a}}$ & $31^{\mathrm{a}}$ & $42^{\mathrm{a}}$ & $25^{\mathrm{a}}$ & $24^{\mathrm{a}}$ & $25^{\mathrm{a}}$ & $27^{\mathrm{a}}$ \\
\hline 2011 & $47^{\mathrm{a}}$ & $34^{\mathrm{a}}$ & $37^{\mathrm{a}}$ & $47^{\mathrm{a}}$ & $37^{\mathrm{a}}$ & $38^{\mathrm{a}}$ & $36^{\mathrm{a}}$ & $43^{\mathrm{a}}$ \\
\hline 2012 & $63^{\mathrm{a}}$ & $50^{\mathrm{ab}}$ & $57^{\mathrm{a}}$ & $55^{\mathrm{ab}}$ & $40^{\mathrm{ab}}$ & $59^{\mathrm{ab}}$ & $42^{\mathrm{ab}}$ & $25^{\mathrm{b}}$ \\
\hline
\end{tabular}

$\S$ see Table 3-3 for treatment descriptions.

${ }_{\mathrm{I}}^{\mathrm{I}}$ means for each treatment combination within rows with the same letter are not significantly different at $\mathrm{p}<0.05$.

Extractable calcium concentrations were significantly higher in treatments with mulch applications than in treatments without mulch application. For mulched treatment combinations, average calcium concentration ranged from 41 to $78 \mathrm{cmol}_{\mathrm{c}} \mathrm{kg}^{-1}$ compared to 3 to $6 \mathrm{cmol}_{\mathrm{c}} \mathrm{kg}^{-1}$ on non-mulched treatments (Table 3-9). The high concentrations of extractable calcium in the mulched treatments are most likely due to the limestone gravel which was added as aggregate at the loading site and which became incorporated into the mulch at the sawmill. A negative effect of high calcium concentration in the mulched treatments is that phosphorus may be bound with the calcium to create calcium-phosphate complexes rendering phosphorus unavailable to plants (Lopez-Bucio et al., 2000). Overall, calcium concentrations for non-mulched treatments have declined since 2008 even in gray sandstone treatments which initially had higher concentrations than brown sandstone treatments.

Aluminum, iron, phosphorus, and zinc concentrations were all significantly lower in mulched treatments than in non-mulched treatments with the exception of the brown mulched 
treatment with hydroseeding $(\mathrm{BMH})$. Aluminum concentrations were below detection limits in the GM and GMH treatments (Table 3-9). Iron concentrations ranged from 5 to $22 \mathrm{mg} \mathrm{kg}^{-1}$ in gray sandstone treatments with a mulch application (GM) and in the brown sandstone with mulch (BM) treatment (Table 3-9). Phosphorus concentrations ranged from 2 to $4 \mathrm{mg} \mathrm{kg}^{-1}$ and zinc concentrations averaged $1 \mathrm{mg} \mathrm{kg}^{-1}$ in both gray sandstone mulch treatment combinations (GM and GMH) and the brown sandstone with mulch (BM) treatment (Table 3-9). The BMH treatment had extractable nutrient concentrations that were statistically similar to extractable nutrient concentrations found in brown sandstone only (B) and brown sandstone with hydroseeding $(\mathrm{BH})$ treatments. Aluminum concentrations in $\mathrm{B}, \mathrm{BMH}$, and $\mathrm{BH}$ treatments ranged from 412 to $489 \mathrm{mg} \mathrm{kg}^{-1}$ while $\mathrm{G}$ and $\mathrm{GH}$ treatments ranged from 51 to $85 \mathrm{mg} \mathrm{kg}^{-1}$ (Table 3-9). Iron concentrations were statistically similar in non-mulched treatments as well as the BMH treatment (104 to $280 \mathrm{mg} \mathrm{kg}^{-1}$ ) (Table 3-9).

It is possible that aluminum, iron, and zinc are forming humic substance-metal complexes which will reduce the concentration of exchangeable metals. Thomas (1975) found that increases in soil organic matter resulted in a significant reduction in exchangeable aluminum and therefore inferred that any lack of deleterious effects on plant growth were due to humic substance-metal complexations that removed aluminum and other toxic metals from the soil solution.

As mentioned before, the BMH treatment did not exhibit soil chemical properties similar to other mulched treatments. The 2012 growing season is the first instance since this study began in 2008 that a mulched treatment began to show characteristics of its underlying sandstone type. The EC and $\mathrm{pH}$ values have decreased in this treatment and are beginning to resemble values measured in the non-mulched brown sandstone treatments. Extractable aluminum, iron, phosphorus, and zinc concentrations have greatly increased and favor a similarity to the elemental concentrations of non-mulched brown sandstone treatments. Although the soil chemical properties of this treatment appear to have taken on the features of the underlying sandstone parent material, there were no evident advantageous or deleterious effects to tree growth. Future monitoring will provide better details as to how the underlying sandstone will affect tree growth. 
Table 3-9. 2008 and 2012 soil properties of samples from eight treatments at Arch Coal's Birch River mine in Webster County, WV. 2008 data are from DeLong (2010).

\begin{tabular}{|c|c|c|c|c|c|c|c|c|}
\hline \multirow[b]{2}{*}{ Element } & \multicolumn{8}{|c|}{ Treatments $\S$} \\
\hline & B & $\mathbf{B M}$ & BMH & BH & $\mathbf{G}$ & GM & GMH & GH \\
\hline & ----- & - & ------- & -------- & $\mathrm{ckg}^{-1}-$ & $-\cdots$ & ---------- & ----- \\
\hline \multicolumn{9}{|l|}{$\mathrm{Mg}$} \\
\hline 2008 & $8^{\mathrm{cd} \mathrm{I}}$ & $7^{\mathrm{abcd}}$ & $14^{\mathrm{abc}}$ & $2^{\mathrm{d}}$ & $6^{\mathrm{bcd}}$ & $19^{\mathrm{ab}}$ & $25^{\mathrm{a}}$ & $10^{\mathrm{abc}}$ \\
\hline 2012 & $3^{\mathrm{a}}$ & $9^{\mathrm{a}}$ & $7^{\mathrm{a}}$ & $4^{\mathrm{a}}$ & $4^{\mathrm{a}}$ & $7^{\mathrm{a}}$ & $7^{\mathrm{a}}$ & $5^{\mathrm{a}}$ \\
\hline \multicolumn{9}{|l|}{ K } \\
\hline 2008 & $0.65^{\mathrm{b}}$ & $0.91^{\mathrm{ab}}$ & $1.40^{\mathrm{a}}$ & $0.73^{\mathrm{ab}}$ & $0.71^{\mathrm{ab}}$ & $1.01^{\mathrm{ab}}$ & $1.40^{\mathrm{a}}$ & $0.91^{\mathrm{ab}}$ \\
\hline 2012 & $0.32^{\mathrm{ab}}$ & $0.16^{\mathrm{ab}}$ & $1.09^{\mathrm{a}}$ & $0.36^{\mathrm{ab}}$ & $0.09^{\mathrm{b}}$ & $0.13^{\mathrm{b}}$ & $0.26^{\mathrm{ab}}$ & $0.17^{\mathrm{ab}}$ \\
\hline \multicolumn{9}{|l|}{$\mathrm{Ca}$} \\
\hline 2008 & $5^{\mathrm{de}}$ & $26^{\mathrm{bc}}$ & $81^{\mathrm{ab}}$ & $2^{\mathrm{e}}$ & $7^{\mathrm{cd}}$ & $57^{\mathrm{ab}}$ & $92^{\mathrm{a}}$ & $13^{\mathrm{cd}}$ \\
\hline 2012 & $3^{b}$ & $78^{\mathrm{a}}$ & $41^{\mathrm{ab}}$ & $4^{b}$ & $4^{b}$ & $72^{\mathrm{a}}$ & $65^{\mathrm{a}}$ & $6^{\mathrm{b}}$ \\
\hline \multicolumn{9}{|l|}{$\mathrm{Al}$} \\
\hline 2008 & $69^{c}$ & $81^{\mathrm{bc}}$ & $337^{\mathrm{a}}$ & $178^{\mathrm{abc}}$ & $271^{\mathrm{a}}$ & $269^{a}$ & $213^{\mathrm{ab}}$ & $282^{\mathrm{a}}$ \\
\hline 2012 & $489^{\mathrm{a}}$ & $58^{\mathrm{bc}}$ & $528^{\mathrm{ab}}$ & $412^{\mathrm{ab}}$ & $51^{\mathrm{abc}}$ & $0^{c}$ & $0^{c}$ & $85^{\mathrm{abc}}$ \\
\hline \multicolumn{9}{|l|}{$\mathrm{Fe}$} \\
\hline 2008 & $384^{\mathrm{b}}$ & $314^{\mathrm{b}}$ & $37^{\mathrm{c}}$ & $497^{\mathrm{b}}$ & $1608^{\mathrm{ab}}$ & $1034^{\mathrm{ab}}$ & $454^{\mathrm{b}}$ & $3270^{\mathrm{a}}$ \\
\hline 2012 & $132^{\mathrm{a}}$ & $22^{\mathrm{b}}$ & $168^{\mathrm{a}}$ & $142^{\mathrm{a}}$ & $104^{\mathrm{a}}$ & $5^{b}$ & $7^{\mathrm{b}}$ & $280^{\mathrm{a}}$ \\
\hline \multicolumn{9}{|l|}{$\mathrm{Mn}$} \\
\hline 2008 & $144^{\mathrm{d}}$ & $217^{\mathrm{bcd}}$ & $273^{b c d}$ & $168^{\mathrm{cd}}$ & $336^{\mathrm{abc}}$ & $589^{\mathrm{ab}}$ & $873^{a}$ & $510^{\mathrm{ab}}$ \\
\hline 2012 & $14^{\mathrm{ab}}$ & $27^{\mathrm{ab}}$ & $182^{\mathrm{a}}$ & $102^{\mathrm{ab}}$ & $19^{\mathrm{ab}}$ & $13^{\mathrm{b}}$ & $13^{\mathrm{b}}$ & $29^{\mathrm{ab}}$ \\
\hline \multicolumn{9}{|l|}{$\mathrm{P}$} \\
\hline 2008 & $22^{\mathrm{cd}}$ & $32^{\mathrm{bc}}$ & $7^{\mathrm{e}}$ & $15^{\text {cde }}$ & $96^{\mathrm{a}}$ & $38^{\mathrm{abc}}$ & $10^{\mathrm{de}}$ & $101^{\mathrm{ab}}$ \\
\hline 2012 & $10^{\mathrm{abc}}$ & $4^{\mathrm{bcd}}$ & $22^{\mathrm{ab}}$ & $35^{\mathrm{ab}}$ & $33^{\mathrm{a}}$ & $2^{\mathrm{d}}$ & $2^{\mathrm{cd}}$ & $52^{\mathrm{a}}$ \\
\hline \multicolumn{9}{|l|}{$\mathrm{Zn}$} \\
\hline 2008 & $21^{\mathrm{ab}}$ & $33^{\mathrm{a}}$ & $9^{b}$ & $16^{\mathrm{ab}}$ & $26^{\mathrm{ab}}$ & $29^{\mathrm{ab}}$ & $10^{\mathrm{b}}$ & $30^{\mathrm{ab}}$ \\
\hline 2012 & $3^{\mathrm{ab}}$ & $1^{\mathrm{bc}}$ & $12^{\mathrm{a}}$ & $19^{\mathrm{a}}$ & $1^{\mathrm{ab}}$ & $1^{\mathrm{c}}$ & $1^{\mathrm{c}}$ & $3^{\mathrm{a}}$ \\
\hline
\end{tabular}

$\S$ see Table 3-3 for treatment descriptions.

${ }_{\mathrm{t}}$ means for each treatment combination within rows with the same letter are not significantly different at $\mathrm{p}<0.05$.

\subsubsection{Ground Cover}

Treatments with mulch and hydroseeding applications had the highest average total ground cover percentages; $60 \%$ for brown sandstone with mulch and hydroseeding (BMH) and $66 \%$ for gray sandstone with mulch and hydroseeding (GMH) (Table 3-10). The gray sandstone only (GSS) treatment had the lowest average total ground cover at $11 \%$ while all other treatment combinations averaged 30 to $42 \%$ total ground cover (Table 3-10). 
Table 3-10. Mean ground cover on eight soil treatments in 2012 at Arch Coal's Birch River mine in Webster County, WV.

\begin{tabular}{lllllllll}
\hline & & \multicolumn{7}{c}{ Treatments $\$$} \\
Cover & B & BM & BMH & BH & G & GM & GMH & GH \\
\hline Herbaceous & $12^{\text {de } \mathrm{f}}$ & $18^{\mathrm{bcde}}$ & $34^{\mathrm{ab}}$ & $30^{\mathrm{abc}}$ & $3^{\mathrm{e}}$ & $16^{\text {cde }}$ & $39^{\mathrm{a}}$ & $22^{\text {bcd }}$ \\
Litter & $3^{\mathrm{ab}}$ & $5^{\mathrm{ab}}$ & $7^{\mathrm{a}}$ & $3^{\mathrm{ab}}$ & $0^{\mathrm{b}}$ & $4^{\mathrm{ab}}$ & $10^{\mathrm{a}}$ & $1^{\mathrm{b}}$ \\
Tree & $15^{\mathrm{a}}$ & $15^{\mathrm{a}}$ & $19^{\mathrm{a}}$ & $9^{\mathrm{a}}$ & $8^{\mathrm{a}}$ & $21^{\mathrm{a}}$ & $17^{\mathrm{a}}$ & $9^{\mathrm{a}}$ \\
Total & $30^{\mathrm{b}}$ & $38^{\mathrm{b}}$ & $60^{\mathrm{a}}$ & $42^{\mathrm{b}}$ & $11^{\mathrm{c}}$ & $41^{\mathrm{b}}$ & $66^{\mathrm{a}}$ & $32^{\mathrm{b}}$ \\
Cover & & & & & & & & \\
Bare/Rock & $70^{\mathrm{ab}}$ & $62^{\mathrm{b}}$ & $40^{\mathrm{cd}}$ & $55^{\mathrm{bc}}$ & $88^{\mathrm{a}}$ & $59^{\mathrm{b}}$ & $34^{\mathrm{d}}$ & $68^{\mathrm{b}}$ \\
Water & $0^{\mathrm{a}}$ & $0^{\mathrm{a}}$ & $0^{\mathrm{a}}$ & $3^{\mathrm{a}}$ & $1^{\mathrm{a}}$ & $0^{\mathrm{a}}$ & $0^{\mathrm{a}}$ & $0^{\mathrm{a}}$ \\
\hline
\end{tabular}

$\S$ see Table 3-3 for treatment descriptions.

${ }_{\mathrm{I}}^{\mathrm{I}}$ means for each treatment combination within rows with the same letter are not significantly different at $\mathrm{p}<0.05$.

\subsection{Conclusions}

Overall, sandstone type, bark mulch application, and hydroseed application all greatly influenced tree growth. Brown sandstone produced greater tree volume indices than gray sandstone, $5,333 \mathrm{~cm}^{3}$ vs. $3,031 \mathrm{~cm}^{3}$, and continues to show that it is a more suitable topsoil substitute than unweathered gray sandstone when forestry is the assigned post-mining land use. Mulch application significantly altered the brown and gray sandstone chemical properties in a way that masked the features of the underlying sandstone with the exception of the BMH treatment. The BMH treatment, for the first time since 2008, displayed soil chemical properties that resembled its sandstone parent material. However, this shift in chemical properties did not appear to influence overall tree volume index. Topsoil substitutes (gray sandstone) amended with bark mulch seem to support healthy tree growth and may be an advisable reclamation method for reforestation. Hydroseed application did not inhibit tree growth, but appeared to have positive effects on tree volume index: $5,809 \mathrm{~cm}^{3}$ compared to $3,403 \mathrm{~cm}^{3}$. 


\subsection{Literature Cited}

Angel, P.N., D.H. Graves, C. Barton, R.C. Warner, P.W. Conrad, R.J. Sweigard, and C. Agouridis. 2006. Evaluation of tree responses to low compaction surface mine reclamation. P. 45-58. In: Barnhisel, R. (ed.), Proceedings, 2006 American Society of Mining and Reclamation, March 26-30, 2006, St. Louis, MO.

Angel, P.N., C.D. Barton, R.C. Warner, C. Agouridis, T. Taylor, and S.L. Hall. 2008. Tree growth, natural regeneration, and hydrologic characteristics of three loose-graded surface mine spoil types in Kentucky. p. 28-65. In: Barnhisel R. (ed), Proceedings, 2008 American Society of Mining and Reclamation, June 14-18, 2008, Richmond, VA.

Bendfeldt, E.S., J.A. Burger, and W.L. Daniels. 2001. Quality of amended mine soils after sixteen years. Soil Sci. Soc. Am. J. 65: 1736-1744.

Conrad, P.W., R.J. Sweigard, V. Badaker, D.H. Graves, and C.D. Barton. 2008. The impact of surface applied mulches on selected physical properties of reclaimed mountaintop removal sites. Intern. J. Mining, Reclamation and Environment 22: 222-236.

Daniels, W.L., and C.E. Zipper. 1988. Improving coal surface mine reclamation in the Central Appalachian region. p. 139-162. In: Cairns, J. (ed.), Rehabilitating damaged ecosystems. Vol. I. CRC Press, Boca Raton, FL.

DeLong, C. 2010. Evaluation of reforestation efforts on two reclaimed surface mines in West Virginia. M.S. Thesis, West Virginia University, Morgantown, WV.

Emerson, P., J. Skousen, and P. Ziemkiewicz. 2009. Survival and growth of hardwoods in brown versus gray sandstone on a surface mine in West Virginia. J. Environ. Qual. 38:18211829

Fields-Johnson, C., C.E. Zipper, J.A. Burger, and D.M. Evans. 2010. Second year response of Appalachian mixed hardwoods to soil surface grading and herbaceous ground cover. p. 305-318. In: Barnhisel, R. (ed.), Proceedings, 2010 American Society of Mining and Reclamation, June 5-11, 2010, Pittsburgh, PA.

Fields-Johnson, C.W., C.E. Zipper, J.A. Burger, and D.M. Evans. 2012. Forest restoration on steep slopes after coal surface mining in Appalachian USA: Soil grading and seeding effects. Forest Ecol. Manage. 270: 126-134.

Franklin, J.A., C.E. Zipper, J.A. Burger, J.G. Skousen, and D.F. Jacobs. 2012. Influence of herbaceous ground cover on forest restoration of eastern US coal surface mines. New Forests 43: 905-924. 
Godman, R. M. 1965. Sugar maple (Acer saccharum Marsh.). p. 673. In: Fowells, H. (ed.), Silvics of forest trees of the United States. U.S. Department of Agriculture, Forest Service, Agric. Handb. 271. U.S. Government Printing Office, Washington, DC.

Haering, K.C., W.L. Daniels, and J.M. Galbraith. 2004. Appalachian mine soil morphology and properties: Effects of weathering and mining method. Soil Sci. Soc. Am. J. 68: 13151325.

Harman, G., R. Patrick, and T. Spittler. 2007. Removal of heavy metals from polluted waters using lignocellulosic agricultural waste products. Industrial Biotechnology 3: 366-374.

Hicks Jr., R.R., 1998. Ecology and management of central hardwood forests. John Wiley \& Sons, New York.

Holl, K.D. 2002. Long-term vegetation recovery on reclaimed coal surface mines in the eastern USA. J. Appl. Ecol. 39: 960-970.

Huntley, J.C. 1990. Robinia pseudoacacia L. Black Locust. P. 605-613. Burns, R., and Honkala, B. (eds.), In: Silvics of North America, Vol. 2, Hardwoods. U.S. Department of Agriculture, Forest Service, Agric. Handb. 654, U.S. Government Printing Office, Washington, DC.

Kost, D.A., J.P. Vimmerstedt, and J.H. Brown. 1998. Topsoil, ripping, and fertilization effects on tree growth and nutrition on calcareous minesoils. For. Ecol. Manage. 103: 307-319.

Larkin, J.L., D. Maehr, J. Krupa, J. Cox, K. Alexy, D. Unger, and C. Barton. 2008. Small mammal response to vegetation and spoil conditions on a reclaimed surface mine in Eastern Kentucky. Southeastern Naturalist 3: 401-412.

Loch, R.I. 2000. Effects of vegetation cover on runoff and erosion under simulated rain and overland flow on a rehabilited site on the Meanda Mine, Tarong, Queensland. Australian J. Soil Research 38: 299-312.

Lopez-Bucio, J., O. Martinez de la Vega, A. Guevara-Garcia, and L. Herrera-Estrella. 2000. Enhanced phosphorus uptake in transgenic tobacco plants that overproduce citrate. Nature Biotechnology 18: 450-453.

Lux, H.B. and J.R. Cumming. 1999. Effect of aluminum on the growth and nutrition of tulippoplar seedlings. Can. J. For. Res. 29: 2003-2007.

McFee, W.W., W.R. Byrnes, and J.G. Stockton. 1981. Characteristics of coal mine overburden important to plant growth. J. Environ. Qual. 10: 300-308. 
Miller, J., C. Barton, C. Agourdis, A. Fogel, T.Dowdy, and P. Angel. 2010. Evaluating soil genesis and reforestation success on a surface coal mine in Appalachia. Soil Sci. Soc. Am. J. 76: 950-960.

Neumann, U. 1973. Succession of soil fauna in afforested spoil banks of the brown-coal mining district of Cologne. p. 335-348. In: Ecology and Reclamation of Devastated Land. Vol. I. Gordon and Breach, New York.

Nowak, C.A. 1996. Wood volume increment in thinned, 50-55-year old, mixed species Allegheny hardwoods. Can. J. For. Res. 26: 819-835.

Parr, J.F., and S.B. Hornick. 1992. Agricultural use of organic amendments: A historical perspective. Am. J. Alternative Agric. 7: 181-189.

Pastor, J., J.D. Aber, C.A. McClaugherty, J.M. Melillo. 1982. Geology, soils, and vegetation of Black Hawk Island, Wisconsin. Am. Midland Nat. 108: 266-277.

R Development Core Team. 2012. R: A language and environment for statistical computing, reference index version 2.13.0. R Foundation for Statistical Computing, Vienna, Austria. ISBN 3-90051-08-9, URL http://www.R-project.org. Accessed April 1, 2013.

Rodrigue, J.A., and J.A. Burger. 2004. Forest soil productivity of mined land in the Midwestern and Eastern coalfield regions. Soil Sci. Soc. Am. J. 68: 833-844.

Showalter, J.M., J.A. Burger, and C.E. Zipper. 2010. Hardwood seedling growth on different mine spoil types with and without amendment. J. Environ. Qual. 39: 483-491.

Thomas, C. 2012. Evaluation of tree growth and chemical, physical and biochemical soil properties of two reclaimed surface mines in West Virginia. M.S. Thesis, West Virginia University, Morgantown, WV.

Thomas, C., and J. Skousen. 2011. Hardwood tree performance on amended brown and gray mine spoils after four years. p. 655-675. In: Barnhisel, R. (ed.), Proceedings, 2011 American Society of Mining and Reclamation, June 12-16, 2011. Bismarck, ND.

Thomas, G.W. 1975. Relationship between organic matter content and exchangeable aluminum in acid soil. Soil Sci. Soc. Am. Proc. 39: 591- 599.

Torbert, J.L., J.A. Burger, and W.L. Daniels. 1989. Pine growth variation associated with overburden rock type on a reclaimed surface mine in Virginia. J. Environ. Qual. 19: 8892.

Torbert, J.L., A.R. Tuladhar, J.A. Burger, and J.C. Bell. 1988. Mine soil property effects on the height of 10-year-old white pine. J. Environ. Qual. 17: 189-192. 
United States Department of Agriculture, Natural Resources Conservation Service. 2012. PLANTS Database. Available at http://plants.usda.gov/java/ Accessed 15 February 2013.

Vogel, W.G. 1973. Effect of herbaceous vegetation on survival and growth of trees planted on coal-mine spoils. p. 197-207. In: Res. Appl. Technol. Symp., Mined-Land Reclamation, March 1973, Pittsburgh, PA. United States Department of Agriculture. Washington, DC.

Whiting, D., A. Card, C. Wilson, and J. Reeder. 2010. Saline soils. Colorado Master Gardener Program, Colorado State University Extension. Available at: http://www.cmg.colostate.edu/gardennotes/224.html. Accessed April 1, 2013.

Whitney, G.G. 1997. Sugar maple: Abundance and site relationships in the pre- and postsettlement forest. p. 14-18. In: Sugar maple ecology and health: Proceedings of an International Symposium. U.S. Department of Agriculture, Forest Service, Northeastern Research Station, Warren, PA. June 2-4.

Zipper, C.E., J.A. Burger, J.G. Skousen, P.N. Angel, C.D. Barton, V. Davis, J.A. Franklin. 2011. Restoring forests and associated ecosystem services on Appalachian coal surface mines. Environmental Management 47: 751-765. 


\section{Tree Foliar Nutrient Study}

\subsection{Literature Review and Objectives}

Research involving tree growth on mined lands examines the many physical and chemical properties of mine soils which affect tree survival and development. Often these studies focus on compaction, soil particle size, electrical conductivity, $\mathrm{pH}$, and available nutrients (Rodrigue and Burger, 2004; Emerson et al., 2009; Conrad et al., 2008). Few studies have been conducted which compare the mine soil nutrient availability and tree foliar nutrient concentrations in trees grown on the mined sites to those of an unmined forest.

Torbert et al. (1990) found nutrient availability in the soil varied with $\mathrm{pH}$ of overburden materials, which influenced the overall tree volume of pitch X loblolly hybrid pine (Pinus X rigitaeda). It was reported that mine soil $\mathrm{pH}$ had the greatest effect on available manganese. Manganese availability decreased as soil $\mathrm{pH}$ increased and resulted in low concentrations in the soil and foliage. This deficiency directly affected tree volume (Torbert et al., 1990). Showalter et al. (2007) found a correlation between nutrient availability in mine soil and foliar nutrient concentration of white oak (Quercus alba). The researchers reported that soil nitrogen levels were deficient and that foliar nitrogen levels were significantly lower when compared to white oak tree leaves growing in a nearby native Appalachian hardwood forest.

The objectives of this study were to determine the effect of overburden type (brown sandstone vs. gray sandstone) and amendment (bark mulch vs. no bark mulch) on soil nutrient concentrations and foliar nutrient concentrations in three deciduous hardwood tree species at the Birch River mine in Webster County, West Virginia, and to compare them to soil and foliar nutrient concentrations in a nearby unmined forest.

\subsection{Methods}

\subsubsection{Study Site}

The location for this study was Arch Coal's Birch River Operation located near Cowen in Webster County, West Virginia ( $38^{\circ} 26^{\prime} 33.324^{\prime \prime} \mathrm{N} 080^{\circ} 36^{\prime} 41.4^{\prime \prime} \mathrm{W}$ ). Details of the site are 
explained in Chapter 3. For the purpose of this experiment, only four of the eight treatments were used: brown sandstone, brown with mulch, gray sandstone, and gray with mulch $(B, B M, G$, and GM) (Table 4-1).

Trees from an unmined section of the Birch River mine were used as a control site for the collection of soil and foliar samples for nutrient analyses (38 $\left.28^{\circ} 22.476^{\prime \prime} \mathrm{N} 080^{\circ} 40^{\prime} 4.44^{\prime \prime} \mathrm{W}\right)$. Figure 4-1 illustrates the location of the forest in relation to the experimental plot. The predominant soil type in the forested area sampled is Dekalb channery sandy loam with naturally low fertility and extremely acid to strongly acid. However, the potential productivity for trees on this soil is considered moderately high (Carpenter, 1992).

Table 4-1. Soil type descriptions at Arch Coal's Birch River mine in Webster County, WV.

\begin{tabular}{lc}
\hline Soil Type & Abbreviation \\
\hline Brown sandstone & $\mathrm{B}$ \\
Brown sandstone with mulch & $\mathrm{BM}$ \\
Gray sandstone & $\mathrm{G}$ \\
Gray sandstone with mulch & $\mathrm{GM}$ \\
Unmined forest & FOR \\
\hline
\end{tabular}




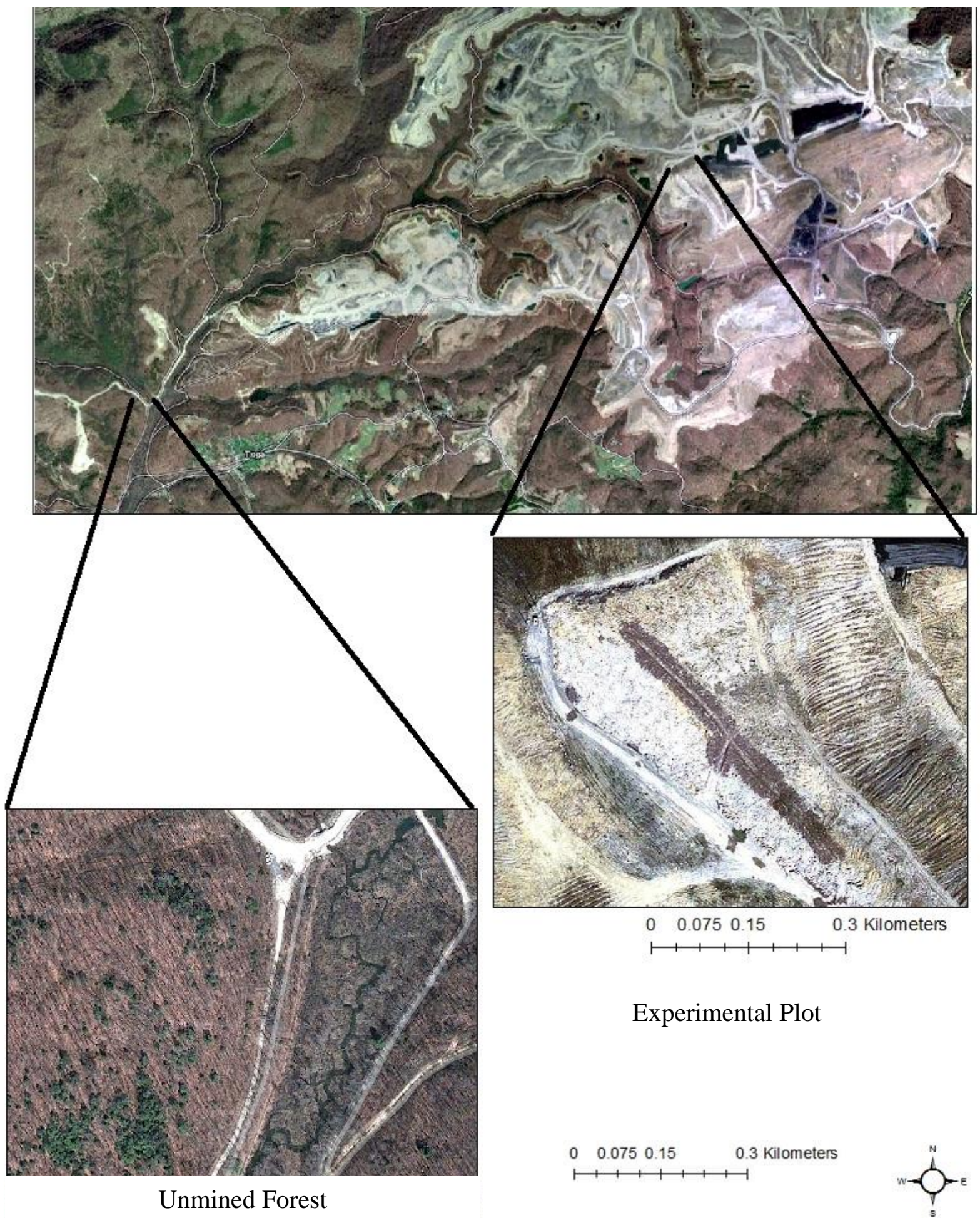

Figure 4-1. Aerial view of Arch Coal's Birch River mine with close-up views of the experimental plot and the unmined forested area in Webster County, WV (Google Maps, 2013). 


\subsubsection{Trees}

Black cherry (Prunus serotina Ehrh.), tulip-poplar (Liriodendron tulipifera L.), and red oak (Quercus rubra L.) were selected for this study due to their importance within the forest ecosystem and their commercial value. Three trees of each species were randomly selected from each treatment type (brown sandstone with and without bark mulch, and gray sandstone with and without bark mulch). Three trees of each species were randomly selected from an unmined forested area within the permitted boundary of Arch Coal's Birch River mine for comparison. A minimum of ten leaves were collected from the mid-section of the current season's terminal shoot growth from the upper portion of the crown. Two leaves from each terminal shoot were sampled. Foliage samples were used for analyzing foliar nutrient concentrations. Soil samples were collected to a depth of $15 \mathrm{~cm}$ and within a $50-\mathrm{cm}$ radius from the base of each tree.

\subsubsection{Foliar Nutrient Testing}

The harvested leaves were oven-dried at $65^{\circ} \mathrm{C}$ for 24 -hrs. Dry foliage was ground with a Capresso Cool Grind Blade coffee grinder to pass a 1-mm sieve. Precisely $0.50 \mathrm{~g}$ of foliage were digested overnight in $10 \mathrm{~mL}$ concentrated $\mathrm{HNO}_{3}$, followed by microwave assisted acid digestion (Showalter et al., 2010). Digests were diluted to $50 \mathrm{~mL}$ with DDI water and filtered through Whatman No. 42 filter paper. Potassium, calcium, magnesium, manganese, phosphorus, aluminum, and iron were determined using a Perkin Elmer Optima DV 2100 emission spectrophotometer (Perkin-Elmer Corp., Norwalk, CT). Peach leaf standards from the National Institute of Standards and Technology (SRM 1547) were digested along with blank samples for control comparison.

\subsubsection{Soil}

Collected soil samples were air dried and sieved to pass a 2-mm screen. The fine soil fraction was used for measuring $\mathrm{pH}$ and extractable nutrients. Soil $\mathrm{pH}$ was determined using $5 \mathrm{~g}$ of soil with $5 \mathrm{ml}$ of DDI water with a Fisher Scientific Accumet pH meter model 915 (Thermo Fisher Scientific Inc., Pittsburgh, PA). Extractable nutrients were determined using a Mehlich 1 extracting solution $\left(0.025 \mathrm{~N} \mathrm{H}_{2} \mathrm{SO}_{4}+0.05 \mathrm{~N} \mathrm{HCl}\right)$. The extracted solution was analyzed for 
potassium, calcium, magnesium, manganese, phosphorous, iron, and aluminum using a Perkin Elmer Optima DV 2100 emission spectrophotometer (Perkin-Elmer Corp., Norwalk, CT).

\subsubsection{Statistical Analysis}

A one-way ANOVA was used to analyze soil and foliar nutrient concentrations. A Tukey's HSD test was used to determine significant differences at a level of $\mathrm{p}<0.05$. All statistical analyses were conducted using the R language (R Core Development Team, 2013).

\subsection{Results and Discussion}

\subsubsection{Black cherry}

Foliar and soil phosphorus concentrations were significantly lower on all four mine soils compared with foliar and soil phosphorus concentrations found in the unmined forest (FOR) (Table 4-2). Concentrations were especially low for black cherry growing on the gray sandstone treatment $(\mathrm{G})$ with a mean foliar phosphorus concentration of $888 \mathrm{mg} \mathrm{kg}^{-1}$ (Table 4-2). Among the four mine soils, large differences were found for foliar phosphorus concentrations. Phosphorus in trees growing in brown sandstone alone were more than double the phosphorus concentrations in trees growing in gray alone. In previous chapters, it was suggested that soil phosphorus on gray sandstone may be unavailable to plants. Similar studies have reported deficient concentrations of foliar phosphorus in hardwood species and have determined that low phosphorus availability on mine soils limits tree growth (Showalter et al., 2010; Torbert et al., 1988; Andrews et al., 1998). 
Table 4-2. Mean foliar nutrient concentrations of black cherry in five soil types.

\begin{tabular}{|c|c|c|c|c|c|}
\hline \multirow[b]{2}{*}{ Nutrient } & \multicolumn{5}{|c|}{ Soil Type § } \\
\hline & G & B & GM & BM & FOR \\
\hline & \multicolumn{5}{|c|}{ ר } \\
\hline $\mathrm{P}$ & $888^{\mathrm{ct}}$ & $2145^{\mathrm{ab}}$ & $1756^{\mathrm{bc}}$ & $1065^{\mathrm{c}}$ & $2798^{\mathrm{a}}$ \\
\hline $\mathrm{K}$ & $10,659^{\mathrm{b}}$ & $14,980^{\mathrm{ab}}$ & $15,893^{\mathrm{ab}}$ & $14,982^{\mathrm{ab}}$ & $20,621^{\mathrm{a}}$ \\
\hline $\mathrm{Ca}$ & 8,755 & 8,880 & 9,230 & 6,186 & 7,063 \\
\hline $\mathrm{Mg}$ & $4158^{\mathrm{c}}$ & $2052^{\mathrm{a}}$ & $3490^{\mathrm{b}}$ & $4175^{\mathrm{bc}}$ & $3009^{\mathrm{ab}}$ \\
\hline $\mathrm{Al}$ & $105^{\mathrm{ab}}$ & $152^{\mathrm{a}}$ & $69^{\mathrm{b}}$ & $59^{\mathrm{b}}$ & $143^{\mathrm{a}}$ \\
\hline $\mathrm{Fe}$ & $83^{\mathrm{ab}}$ & $97^{\mathrm{a}}$ & $69^{\mathrm{b}}$ & $61^{\mathrm{b}}$ & $69^{\mathrm{ab}}$ \\
\hline Mn & $66^{\mathrm{b}}$ & $2051^{\mathrm{a}}$ & $73^{\mathrm{b}}$ & $259^{\mathrm{b}}$ & $145^{\mathrm{b}}$ \\
\hline
\end{tabular}

§ See Table 4-1 for soil type descriptions

${ }^{1}$ means for each element within rows with the same letter are not significantly different at $\mathrm{p}<0.05$.

Foliar potassium concentrations on $\mathrm{G}$ were significantly lower than foliar potassium concentrations in black cherry grown in FOR, $10,659 \mathrm{mg} \mathrm{kg}^{-1}$ compared to $20,621 \mathrm{mg} \mathrm{kg}^{-1}$ (Table 4-2). The $\mathrm{G}$ treatment also had the lowest soil potassium levels, $0.24 \mathrm{cmol}_{\mathrm{c}} \mathrm{kg}^{-1}$, (Table 43 ), and as stated earlier in a previous chapter, low levels of potassium in gray sandstone may be due to leaching which would inevitably cause a decrease in plant uptake of potassium (Bradshaw, 1997). Potassium deficiencies are not commonly reported in mine soil studies, however Showalter et al. (2010) found that foliar potassium concentrations were below literature-based values for white ash (Fraxinus americana L.) grown on weathered and unweathered sandstone overburden derived from a surface mine in West Virginia. 
Table 4-3. Soil chemical properties of five soil types surrounding black cherry at Arch Coal's Birch River mine in Webster County, WV.

\begin{tabular}{|c|c|c|c|c|c|}
\hline \multirow[b]{2}{*}{ Property } & \multicolumn{5}{|c|}{ Soil Type § } \\
\hline & G & B & GM & BM & FOR \\
\hline $\mathrm{pH}$ & $7.4^{\mathrm{at}}$ & $4.5^{\mathrm{b}}$ & $7.8^{\mathrm{a}}$ & $7.7^{\mathrm{a}}$ & $4.7^{\mathrm{b}}$ \\
\hline $\mathrm{Mg}$ & $3.9^{\mathrm{ab}}$ & $1.1^{\mathrm{b}}$ & $5.5^{\mathrm{a}}$ & $5.8^{\mathrm{a}}$ & $2.4^{\mathrm{ab}}$ \\
\hline $\mathrm{K}$ & $0.24^{\mathrm{c}}$ & $0.32^{\mathrm{bc}}$ & $0.84^{\mathrm{at}}$ & $1.0^{\mathrm{a}}$ & $0.84^{\mathrm{ab}}$ \\
\hline $\mathrm{Ca}$ & $7.5^{\mathrm{b}}$ & $3.3^{\mathrm{b}}$ & $57.0^{\mathrm{a}}$ & $45.3^{\mathrm{a}}$ & $5.2^{\mathrm{b}}$ \\
\hline $\mathrm{Al}$ & $45^{\mathrm{b}}$ & $384^{\mathrm{ab}}$ & $-\mathrm{mg}$ & $10^{\mathrm{b}}$ & $1531^{\mathrm{a}}$ \\
\hline $\mathrm{Fe}$ & $98^{\mathrm{ab}}$ & $97^{\mathrm{ab}}$ & $9^{\mathrm{b}}$ & $9^{\mathrm{b}}$ & $158^{\mathrm{a}}$ \\
\hline $\mathrm{Mn}$ & 115 & 34 & 72 & 72 & 256 \\
\hline $\mathrm{P}$ & $38^{\mathrm{a}}$ & $80^{\mathrm{a}}$ & $10^{\mathrm{a}}$ & $15^{\mathrm{a}}$ & $153^{\mathrm{b}}$ \\
\hline
\end{tabular}

$\S$ See Table 4-1 for plot descriptions

${ }^{\mathrm{I}}$ means for each property within rows with the same letter are not significantly different at $\mathrm{p}<$ 0.05 .

Foliar calcium concentrations on the mine soils were above the mean foliar calcium concentration in the unmined forest, $7,063 \mathrm{mg} \mathrm{kg}^{-1}$, with the exception of the BM treatment (Table 4-2). It is unknown why foliar concentrations were so low on BM when soil calcium concentrations were high, $45 \mathrm{cmol}_{\mathrm{c}} \mathrm{kg}^{-1}$, and soil $\mathrm{pH}$ was suitable for plant-availability of the nutrient (Table 4-3). Mean foliar calcium concentrations ranged from $6,186 \mathrm{mg} \mathrm{kg}^{-1}$ on BM to 9,230 $\mathrm{mg} \mathrm{kg}^{-1}$ on GM, although there was no statistically significant difference (Table 4-2).

Foliar magnesium concentrations were significantly lower on B compared to FOR, 2052 $\mathrm{mg} \mathrm{kg}^{-1}$ vs. $3009 \mathrm{mg} \mathrm{kg}^{-1}$, however, the highest magnesium concentration was on BM, 4,175 mg $\mathrm{kg}^{-1}$ (Table 4-2). Low foliar magnesium on $\mathrm{B}$ is most likely due to the strongly acidic $\mathrm{pH}$ value measured on this soil, 4.5 (Table 4-3). The B mine soil also had the lowest soil magnesium concentrations (Table 4-3). Table 4-4 lists the range of foliar values for the four mine soils and the unmined forest. 
Table 4-4. Range of values for foliar nutrient concentrations of black cherry in five soil types.

\begin{tabular}{lccccc}
\hline \multirow{2}{*}{ Nutrient } & \multicolumn{5}{c}{ Soil Type $\$$} \\
\cline { 2 - 6 } & $\mathbf{G}$ & $\mathbf{B}$ & $\mathbf{G M}$ & BM & FOR \\
\hline & $--------------------------------\mathrm{mg} \mathrm{kg}^{-1}-------------------------------$ \\
$\mathrm{P}$ & $555-1600$ & $1606-2588.6$ & $1655-1933$ & $489.9-1658$ & $2016-3605$ \\
$\mathrm{~K}$ & $9895-12325$ & $13401-16561$ & $13818-17472$ & $6767-19712$ & $17160-24173$ \\
$\mathrm{Ca}$ & $8063-9379$ & $7543-11017$ & $8823-10019$ & $3432-10228$ & $4442-9727$ \\
$\mathrm{Mg}$ & $3135-5092$ & $908.5-2905$ & $2294-4656.5$ & $3611-5386$ & $2991.3-3031$ \\
$\mathrm{Al}$ & $70-137.9$ & $118.1-234$ & $55.5-85.4$ & $23.2-89.6$ & $58.8-218$ \\
$\mathrm{Fe}$ & $72.6-98.1$ & $79.3-124.4$ & $63.1-78.8$ & $24.9-85.9$ & $53.6-78.1$ \\
$\mathrm{Mn}$ & $17.6-151.6$ & $1207-2851$ & $24.32-138.6$ & $89.4-608.1$ & $55.1-236.3$ \\
\hline
\end{tabular}

$\S$ See Table 4-1 for soil type descriptions

Mean foliar aluminum concentrations ranged from $59 \mathrm{mg} \mathrm{kg}^{-1}$ on $\mathrm{BM}$ to $152 \mathrm{mg} \mathrm{kg}^{-1}$ on B (Table 4-2). The highest values were on B and FOR which also had the lowest soil pH values and hence the highest soil aluminum values (Table 4-3). Currently, no literature is available which list the concentration at which aluminum becomes toxic to black cherry growth. Henry (1973) reported that black cherry requires an average of $32 \mathrm{mg} \mathrm{kg}^{-1}$ for healthy growth, a value that all soil types exceeded in this study. Schaedle et al. (1988) described black cherry as highly resistant to aluminum toxicity. However, without literature-based values it is uncertain if the measured foliar aluminum concentrations on B and FOR are growth limiting.

\subsubsection{Red oak}

Measured foliar phosphorus concentrations indicated that available soil phosphorus was possibly deficient on G compared with foliar phosphorus concentrations in FOR (Table 4-5). All the treatments were significantly different from one another with regards to foliar phosphorus levels, and the GM treatment had the highest concentration at $1,583 \mathrm{mg} \mathrm{kg}^{-1}$ compared to $621 \mathrm{mg}$ $\mathrm{kg}^{-1}$ on $\mathrm{G}$ (Table 4-5). Showalter et al. (2010) reported similar findings for red oak grown on forest topsoil, weathered sandstone, unweathered sandstone, and unweathered shale. The results showed that foliar phosphorus concentrations were inadequate on all four soil types and that those levels were strongly correlated with tree growth suggesting that phosphorus was a growth limiting factor on those mine soils (Showalter et al., 2010). For this study, soil phosphorus 
concentrations were greatest for the unmined forest (FOR), $652 \mathrm{mg} \mathrm{kg}^{-1}$, however foliar phosphorus concentrations were significantly lower than two of the mine soils, B and GM (Table 4-5). The lower phosphorus uptake on FOR may be due to extremely high concentrations of soil aluminum at 2,122 mg kg${ }^{-1}$ and a soil $\mathrm{pH}$ of 3.7. At $\mathrm{pH}$ less than 5.8, phosphorus can react with aluminum and iron to produce insoluble aluminum and iron phosphates (Table 4-6) (Abaye et al., 2006).

Table 4-5. Mean foliar nutrient concentrations of red oak in five soil types.

\begin{tabular}{lccccc}
\hline & \multicolumn{5}{c}{ Soil Type $\S$} \\
\cline { 2 - 6 } Nutrient & $\mathbf{G}$ & $\mathbf{B}$ & $\mathbf{G M}$ & $\mathbf{B M}$ & FOR \\
\hline & $--1^{\mathrm{d} \mathrm{d}}$ & $1393^{\mathrm{ab}}$ & $1583^{\mathrm{a}}$ & $923^{\mathrm{c}}$ & $1266^{\mathrm{b}}$ \\
$\mathrm{P}$ & $62,083^{\mathrm{c}}$ & $8,528^{\mathrm{b}}$ & $10,591^{\mathrm{a}}$ & $11,535^{\mathrm{a}}$ & $9,529^{\mathrm{ab}}$ \\
$\mathrm{K}$ & $7,879^{\mathrm{abc}}$ & $6,591^{\mathrm{bc}}$ & $11,356^{\mathrm{a}}$ & $11,760^{\mathrm{ab}}$ & $5,281^{\mathrm{c}}$ \\
$\mathrm{Ca}$ & $5,740^{\mathrm{a}}$ & $1,960^{\mathrm{cd}}$ & $2,446^{\mathrm{c}}$ & $3,577^{\mathrm{b}}$ & $1,331^{\mathrm{d}}$ \\
$\mathrm{Mg}$ & 108 & 138 & 94 & 100 & 99 \\
$\mathrm{Al}$ & 96 & 108 & 122 & 119 & 109 \\
$\mathrm{Fe}$ & $275^{\mathrm{b}}$ & $4,714^{\mathrm{a}}$ & $624^{\mathrm{b}}$ & $771^{\mathrm{b}}$ & $740^{\mathrm{b}}$ \\
$\mathrm{Mn}$ & & & & &
\end{tabular}

$\S$ See Table 4-1 for soil type descriptions

${ }^{\mathrm{t}}$ means for each property within rows with the same letter are not significantly different at $\mathrm{p}<0.05$.

Table 4-6. Soil chemical properties of five soil types surrounding red oak at Arch Coal's Birch River mine in Webster County, WV.

\begin{tabular}{lccccc}
\hline & \multicolumn{5}{c}{ Soil Type $\S$} \\
\cline { 2 - 6 } Property & G & B & GM & BM & FOR \\
\hline & $-1.3^{\mathrm{a}}$ & $4.5^{\mathrm{b}}$ & $7.7^{\mathrm{a}}$ & $7.7^{\mathrm{a}}$ & $3.7^{\mathrm{c}}$ \\
$\mathrm{nyy}$ & $--6^{\mathrm{bc}}$ & $1.7^{\mathrm{c}}$ & $6.9^{\mathrm{ab}}$ & $7.8^{\mathrm{a}}$ & $0.64^{\mathrm{c}}$ \\
$\mathrm{Mg}$ & $0.27^{\mathrm{b}}$ & $0.30^{\mathrm{b}}$ & $0.66^{\mathrm{a}}$ & $0.63^{\mathrm{a}}$ & $0.51^{\mathrm{ab}}$ \\
$\mathrm{Ca}$ & $9.8^{\mathrm{b}}$ & $1.3^{\mathrm{b}}$ & $74.0^{\mathrm{a}}$ & $55.3^{\mathrm{a}}$ & $1.2^{\mathrm{b}}$ \\
$\mathrm{Al}$ & $45^{\mathrm{c}}$ & $212^{\mathrm{b}}$ & $45^{\mathrm{c}}$ & $59^{\mathrm{c}}$ & $2122^{\mathrm{a}}$ \\
$\mathrm{Fe}$ & $131^{\mathrm{c}}$ & $67^{\mathrm{c}}$ & $5^{\mathrm{b}}$ & $49^{\mathrm{b}}$ & $461^{\mathrm{a}}$ \\
$\mathrm{Mn}$ & 106 & 32 & 119 & 159 & 36 \\
$\mathrm{P}$ & $50^{\mathrm{b}}$ & $6^{\mathrm{b}}$ & $7^{\mathrm{b}}$ & $16^{\mathrm{b}}$ & $652^{\mathrm{a}}$ \\
\hline
\end{tabular}

$\S$ See Table 4-1 for plot descriptions

${ }^{\mathrm{I}}$ means for each property within rows with the same letter are not significantly different at $\mathrm{p}<$ 0.05 . 
Foliar potassium concentrations were the lowest on $\mathrm{G}, 6,083 \mathrm{mg} \mathrm{kg}^{-1}$ (Table 4-5). The $\mathrm{G}$ mine soil also had the lowest soil potassium levels at $0.27 \mathrm{cmol}_{\mathrm{c}} \mathrm{kg}^{-1}$ (Table 4-6). This study found that red oak growing on mulched treatments, GM and BM, had significantly higher foliar potassium concentrations than red oak growing in the unmined forest (Table 4-5).). Showalter et al. (2010) reported that foliar potassium concentrations in red oak grown on unweathered sandstone, 5,900 $\mathrm{mg} \mathrm{kg}^{-1}$, were below literature-based norms.

Foliar calcium and magnesium concentrations were significantly greater on mulched treatments, GM and BM, than on FOR and B (Table 4-5). The B and FOR soils also had the lowest mean soil calcium and soil magnesium concentrations compared to G, GM, and BM (Table 4-6). Mean pH values on the B and FOR soils were very strongly to extremely acidic, 4.5 and 3.7, respectively (Table 4-6). On acidic soils, calcium and magnesium become less plantavailable (Abaye et al., 2006). Calcium aids in cell elongation and division, membrane permeability, and enzyme activation (Brady and Weil, 2008). When calcium is deficient, the rooting system is negatively affected thereby making the roots shorter and denser than normal and it makes plants more susceptible to aluminum toxicity on very acidic soils (Abaye et al., 2006; Brady and Weil, 2008).

While it is unclear at what point aluminum becomes toxic to red oak, the B mine soil had the highest concentration of foliar aluminum with a mean of $138 \mathrm{mg} \mathrm{kg}^{-1}$ (Table 4-5). However, the range of foliar aluminum concentrations in FOR included samples with values which measured up to $172.3 \mathrm{mg} \mathrm{kg}^{-1}$ (Table 4-7).

Table 4-7. Range of values for foliar nutrient concentrations of red oak in five soil types.

\begin{tabular}{|c|c|c|c|c|c|}
\hline \multirow[b]{2}{*}{ Nutrient } & \multicolumn{5}{|c|}{ Soil Type $\S$} \\
\hline & $\mathbf{G}$ & B & GM & BM & FOR \\
\hline & & & $-\mathrm{mg} \mathrm{kg}^{-1}$ & & \\
\hline $\mathrm{P}$ & $568.8-674$ & $1214.1-1632$ & $1535-1645$ & $649.2-1063$ & $1179-1371$ \\
\hline $\mathrm{K}$ & $5665-6330$ & $7415-9469$ & $9105-12316$ & $8853-13028$ & $7771-10797$ \\
\hline $\mathrm{Ca}$ & $6539-10058$ & $6236-6903$ & $8151-15427$ & $7280-19633$ & $4043-6704$ \\
\hline $\mathrm{Mg}$ & $5556-6026$ & $1570-2161.5$ & $1995-3294$ & $2937-4138.3$ & $1210-1453$ \\
\hline $\mathrm{Al}$ & $92.9-146.5$ & $120.1-156.1$ & $75.9-117.6$ & $59.9-131.9$ & $52.6-172.3$ \\
\hline $\mathrm{Fe}$ & $83.8-109.3$ & $93.6-133.6$ & $89.1-238.4$ & $104.7-146.7$ & $58.8-166.2$ \\
\hline Mn & $150.8-522.4$ & $3665-5925$ & $204.6-870$ & $81.8-1858$ & $467.8-921.5$ \\
\hline
\end{tabular}

$\S$ See Table 4-1 for soil type descriptions 


\subsubsection{Tulip-poplar}

As with the previous two tree species, foliar phosphorus levels were significantly lower in tulip-poplar growing on the mine soils than in the unmined forest with the lowest concentrations on $\mathrm{G}$ (Table 4.8). Tulip-poplar trees growing in the unmined forest (FOR) contained a mean foliar phosphorus concentration of $2,356 \mathrm{mg} \mathrm{kg}^{-1}$ compared to mean concentrations less than $1,600 \mathrm{mg} \mathrm{kg}^{-1}$ on the mine soils (Table 4-8). Showalter et al. (2010) reported deficient foliar phosphorus concentrations in tulip-poplar grown on forest topsoil, weathered sandstone, unweathered sandstone, and unweathered shale. Mean values ranged from $680 \mathrm{mg} \mathrm{kg}^{-1}$ on unweathered sandstone to $980 \mathrm{mg} \mathrm{kg}^{-1}$ on weathered sandstone. Although the mean foliar phosphorus concentrations on the four mine soils were not significantly different, each treatment had a wide range of values (Table 4-9). As expected, the soil phosphorus concentrations were significantly higher on FOR than on the four mine soils (Table 4-10).

Table 4-8. Mean foliar nutrient concentrations of tulip-poplar in five soil types.

\begin{tabular}{|c|c|c|c|c|c|}
\hline \multirow[b]{2}{*}{ Nutrient } & \multicolumn{5}{|c|}{ Soil Type $\S$} \\
\hline & $\mathbf{G}$ & $\overline{\mathbf{B}}$ & GM & BM & FOR \\
\hline & & & $--m g ~ k g$ & & \\
\hline $\mathrm{P}$ & $927^{\mathrm{bt}}$ & $1,102^{\mathrm{b}}$ & $1,552^{\mathrm{b}}$ & $1,173^{\mathrm{b}}$ & $2,356^{\mathrm{a}}$ \\
\hline $\mathrm{K}$ & $10,285^{\mathrm{a}}$ & $11,382^{b}$ & $13,909^{\mathrm{ab}}$ & $14,650^{\mathrm{ab}}$ & $21,251^{\mathrm{a}}$ \\
\hline $\mathrm{Ca}$ & $12,505^{\mathrm{a}}$ & $7,010^{\mathrm{bc}}$ & $12,941^{\mathrm{a}}$ & $9,581^{\mathrm{ab}}$ & $5,548^{\mathrm{c}}$ \\
\hline $\mathrm{Mg}$ & $8,596^{\mathrm{a}}$ & $7,058^{\mathrm{a}}$ & $3,909^{b}$ & $3,268^{b}$ & $2,076^{\mathrm{b}}$ \\
\hline $\mathrm{Al}$ & $64^{c}$ & $313^{\mathrm{b}}$ & $100^{\mathrm{c}}$ & $53^{\mathrm{c}}$ & $404^{\mathrm{a}}$ \\
\hline $\mathrm{Fe}$ & 94 & 79 & 83 & 74 & 85 \\
\hline Mn & $49^{\mathrm{b}}$ & $1,098^{\mathrm{a}}$ & $113^{\mathrm{b}}$ & $76^{\mathrm{b}}$ & $444^{\mathrm{a}}$ \\
\hline
\end{tabular}

$\S$ See Table 4-1 for soil type descriptions

${ }^{\mathrm{t}}$ means for each property within rows with the same letter are not significantly different at $\mathrm{p}<0.05$. 
Table 4-9. Range of values for foliar nutrient concentrations of tulip-poplar in five soil types.

\begin{tabular}{|c|c|c|c|c|c|}
\hline \multirow[b]{2}{*}{ Nutrient } & \multicolumn{5}{|c|}{ Soil Type § } \\
\hline & G & B & GM & BM & FOR \\
\hline & & & $\mathrm{kg}^{-1}-$ & & \\
\hline $\mathrm{P}$ & $727-1150.2$ & $1082.4-1147$ & $1299-1954$ & $827.3-1330$ & $1720-3343$ \\
\hline $\mathrm{K}$ & $6882-12800$ & $7502-13384$ & $10780-14938$ & $11344-16691$ & $17906-24121$ \\
\hline $\mathrm{Ca}$ & $8183-16084$ & $5937-7998.2$ & $10952-15021$ & $9285-10078$ & $2206-7657$ \\
\hline $\mathrm{Mg}$ & $5451-10662$ & $5782-7893$ & $3013-5257$ & $2537-3832$ & $1749-2264$ \\
\hline $\mathrm{Al}$ & $24-109.5$ & $304.2-320.5$ & $44.9-197.1$ & $24.8-84.4$ & $363.7-439$ \\
\hline $\mathrm{Fe}$ & $85.9-100.5$ & $72.9-89.7$ & $73.1-91.6$ & $62-103.8$ & $70.3-112.8$ \\
\hline $\mathrm{Mn}$ & $27.2-88.8$ & $776-1435$ & $32.1-212.3$ & $38.06-188.4$ & $351.1-556.1$ \\
\hline
\end{tabular}

$\S$ See Table 4-1 for soil type descriptions

Table 4-10. Soil chemical properties of five soil types surrounding tulip-poplar at Arch Coal's Birch River mine in Webster County, WV.

\begin{tabular}{|c|c|c|c|c|c|}
\hline \multirow[b]{2}{*}{ Property } & \multicolumn{5}{|c|}{ Soil Type $\S$} \\
\hline & G & B & GM & BM & FOR \\
\hline $\mathrm{pH}$ & $7.1^{\mathrm{at}}$ & $4.9^{\mathrm{b}}$ & $7.8^{\mathrm{a}}$ & $7.7^{\mathrm{a}}$ & $3.8^{\mathrm{c}}$ \\
\hline $\mathrm{Mg}$ & $3.3^{\mathrm{b}}$ & $3.6^{\mathrm{b}}$ & $6.1^{\mathrm{a}}$ & $5.4^{\mathrm{a}}$ & $0.50^{\mathrm{c}}$ \\
\hline $\mathrm{K}$ & $0.28^{\mathrm{b}}$ & $0.42^{\mathrm{b}}$ & $0.89^{\mathrm{ab}}$ & $0.71^{\mathrm{a}}$ & $0.46^{\mathrm{ab}}$ \\
\hline $\mathrm{Ca}$ & $7.0^{\mathrm{c}}$ & $2.7^{\mathrm{c}}$ & $67.3^{\mathrm{a}}$ & $81.5^{\mathrm{a}}$ & $0.8^{\mathrm{c}}$ \\
\hline $\mathrm{Al}$ & $38^{\mathrm{b}}$ & $274^{c}$ & $49^{\mathrm{b}}$ & $35^{\mathrm{b}}$ & $2179^{\mathrm{a}}$ \\
\hline $\mathrm{Fe}$ & $87^{\mathrm{b}}$ & $80^{\mathrm{b}}$ & $8^{c}$ & $11^{\mathrm{c}}$ & $442^{\mathrm{a}}$ \\
\hline $\mathrm{Mn}$ & $99^{\mathrm{a}}$ & $62^{\mathrm{b}}$ & $53^{\mathrm{b}}$ & $67^{\mathrm{ab}}$ & $15^{\mathrm{c}}$ \\
\hline $\mathrm{P}$ & $31^{\mathrm{b}}$ & $7^{\mathrm{b}}$ & $10^{\mathrm{b}}$ & $11^{\mathrm{b}}$ & $528^{\mathrm{a}}$ \\
\hline
\end{tabular}

$\S$ See Table 4-1 for plot descriptions

${ }^{\mathrm{t}}$ means for each property within rows with the same letter are not significantly different at $\mathrm{p}<$ 0.05 .

Foliar potassium concentrations on $\mathrm{G}$ and $\mathrm{B}$ were significantly lower than in the FOR. The mean foliar concentrations for $\mathrm{G}$ and $\mathrm{B}$ were $10,285 \mathrm{mg} \mathrm{kg}^{-1}$ and $11,382 \mathrm{mg} \mathrm{kg}^{-1}$, respectively (Table 4-8). The G and B soils also had the lowest soil potassium levels (Table 410). Showalter et al. (2010) reported that foliar potassium concentrations in tulip-poplar grown on weathered and unweathered sandstone were below literature-based norms; $5,810 \mathrm{mg} \mathrm{kg}^{-1}$ on weathered sandstone and 4,400 $\mathrm{mg} \mathrm{kg}^{-1}$ on unweathered sandstone. 
Foliar calcium concentrations were the highest in tulip-poplar growing on G and GM soils. Tulip-poplar is a calcium-demanding species which requires high levels of calcium for adequate growth (Craul, 1992; Adams et al., 2006). The soil calcium concentrations were the greatest in G, GM, and BM and may be able to adequately meet the calcium demands of tulippoplar (Table 4-10). Not surprisingly, foliar calcium concentrations were the lowest where soil and foliar aluminum concentrations were the highest, i.e., in B and FOR soils (Tables 4-8 and 410). Other studies dealing with foliar nutrient status in native hardwood species reported decreased foliar calcium with increases in foliar aluminum on acidic forest soils (White et al., 1999; Adams et al., 2006).

For tulip-poplar, foliar magnesium concentrations were the lowest on FOR. Soil magnesium concentrations were also the lowest on FOR, $0.50 \mathrm{cmol}_{\mathrm{c}} \mathrm{kg}^{-1}$, compared to the four mine soils, which ranged from 3.3 to $6.1 \mathrm{cmol}_{\mathrm{c}} \mathrm{kg}^{-1}$ (Table 4-10). The native forest soil may contain little magnesium due to its highly weathered nature therefore causing reduced foliar magnesium concentrations.

The B and FOR soils produced tulip-poplar which had mean foliar aluminum concentrations which were significantly higher than G, GM, and BM, $313 \mathrm{mg} \mathrm{kg}^{-1}$ and $404 \mathrm{mg}$ $\mathrm{kg}^{-1}$, respectively. The B and FOR soils once again contained the highest mean soil aluminum

concentrations at $274 \mathrm{mg} \mathrm{kg}^{-1}$ and $2,179 \mathrm{mg} \mathrm{kg}^{-1}$ and the lowest soil $\mathrm{pH}$ values at 4.9 and 3.8 , respectively (Table 4-10). As mentioned in a previous chapter, aluminum may be forming humic substance-metal complexes in the mulched treatments which could reduce the concentration of exchangeable aluminum (Thomas, 1975) and thereby reducing deleterious effects on plant growth due to high levels of aluminum.

\subsection{Conclusions}

This study found that foliar phosphorus concentrations were significantly lower in all three tree species growing in the four mine soils compared to trees growing in the unmined forest. Mine soils are known to have phosphorus deficiencies and even when phosphorus is present in soil solution it tends to sorb to fine soil particles rendering it unavailable to plants. Foliar potassium concentrations were consistently low on the gray sandstone soil treatment for 
all three tree species and soil potassium concentrations were always lowest on gray sandstone which may be due to excessive leaching on rocky, coarse-textured soils. Foliar calcium and magnesium concentrations were variable depending on tree species and soil type; abundant for some and lower for others. Foliar aluminum concentrations were consistently highest on brown sandstone and the unmined forest for all tree species. Brown sandstone demonstrated many foliar and soil nutrient values which were statistically close to values measured on the unmined forest. Mulched treatments supplied potassium and magnesium for all three tree species comparable to the FOR soil and significantly reduced foliar uptake of aluminum for black cherry. Gray sandstone displayed low concentrations of several nutrients, which may be indicative of nutrient deficiencies and may limit hardwood tree growth. Poor soil water availability on these coarsetextured mine soils may exacerbate these nutrient deficiencies.

Overall, this study showed that nutrient availability in mine soils for tree growth is usually low compared to concentrations found in native unmined forest soils. Coal mine operators should work closely with foresters and soil scientists to ensure that adequate amounts of original topsoil with organic matter are being replaced and that fertilizer is applied to increase the amount of plant-available nutrients to ultimately re-establish a healthy, productive forest ecosystem. 


\subsection{Literature Cited}

Abaye, A.O., T.J. Basden, D. Beegle, G.D. Bindord, W.L. Daniels, S.W. Duiker, G.K. Evanylo, K.C. Haering, D.J. Hansen, G. Mullins, and R.W. Taylor. 2006. The Mid-Atlantic nutrient management handbook. U. S. Department of Agriculture, Agric. Handb. \#06-02 Government Printing Office, Washington, DC.

Adams, M.B., W.T. Peterjohn, and F.S. Gilliam. 2006. Acidification and nutrient cycling. p. 207-236. In: The Fernow Watershed Acidification Study, U.S. Department of Agriculture, Forest Service, Northeastern Research Station, Parsons, WV. Environmental Pollution Vol. 11, New York, NY.

Andrews, J.A., J.E. Johnson, J.L. Torbert, J.A. Burger, and D.L. Kelting. 1998. Mine soil and site properties associated with early height growth of eastern white pine. J. Environ. Qual. 27: 192-199.

Bradshaw, A. 1997. Restoration of mined lands using natural processes. Ecol. Engineering 8: 255-269.

Brady, N.C., and R.R. Weil. 2002. The nature and properties of soil. Thirteenth ed. Prentice Hall, Upper Saddle River, N.J.

Carpenter, S. 1992. Soil survey of Nicholas County, West Virginia. United States Department of Agriculture, Natural Resources Conservation Service. U.S. Government Printing Office, Washington, DC. Available at http://soildatamart.nrcs.usda.gov/Manuscripts/WV067/0/nicholas.pdf Accessed on June $18,2013$.

Conrad, P.W., R.J. Sweigard, V. Badaker, D.H. Graves, and C.D. Barton. 2008. The impact of surface applied mulches on selected physical properties of reclaimed mountaintop removal sites. Intern. J. Mining, Reclamation and Environment 22: 222-236.

Craul, P.J. 1992. Urban soil in landscape design. Wiley \& Sons, New York, NY. 
Emerson, P., J. Skousen, and P. Ziemkiewicz. 2009. Survival and growth of hardwoods in brown versus gray sandstone on a surface mine in West Virginia. J. Environ. Qual. 38: 18211829.

Google Maps. 2013. Commonwealth of Virginia. DigitalGlobe, GeoEye. USDA Farm Service Agency. Available at http://maps.google.com/maps?hl=en\&tab=wl. Accessed 25 March 2013.

Henry, D.G. 1973. Foliar nutrient concentrations of some Minnesota forest species. Univ. Minn., College of Forestry, Minn. Forestry Res. Notes No. 241. Minneapolis, MN.

R Development Core Team. 2013. R: A language and environment for statistical computing, reference index version 2.13.0. R Foundation for Statistical Computing, Vienna, Austria. ISBN 3-90051-08-9, URL http://www.R-project.org. Accessed 15 February 2013.

Rodrigue, J.A., and J.A. Burger. 2004. Forest soil productivity of mined land in the Midwestern and Eastern coalfield regions. Soil Sci. Soc. Am. J. 68:833-844.

Schaedle, M., F.C. Thornton, D.J. Raynel, and H.B. Tepper. 1988. Response of tree seedlings to aluminum. Tree Physiology 5: 337-356.

Showalter, J.M., J.A. Burger, C.E. Zipper, J.M. Galbraith, and P.F. Donovan. 2007. Influence of mine soil properties on white oak seedling growth: A proposed mine soil classification model. Northern J. Appl. For. 31: 99-107.

Showalter, J.M., J.A. Burger, and C.E. Zipper. 2010. Hardwood seedling growth on different mine spoil types with and without amendment. J. Environ. Qual. 39: 483-491.

Thomas, G.W. 1975. Relationship between organic matter content and exchangeable aluminum in acid soil. Soil Sci. Soc. Am. Proc. 39: 591- 599.

Torbert, J.L., A.R. Tuladhar, J.A. Burger, and J.C. Bell. 1988. Mine soil property effects on the height of 10-year-old white pine. J. Environ. Qual. 17: 189-192.

Torbert, J.L., J.A. Burger, W.L. Daniels. 1990. Pine growth variation with overburden rock type on a reclaimed surface mine in Virginia. J. Environ. Qual. 19: 88-92. 
White, G., I.J. Fernandez, and G. Wiersma. 1999. Impacts of ammonium sulfate treatment on the foliar chemistry of forest trees at the Bear Brook Watershed in Maine (BBWM). Environ. Monitor. Assess. 55: 235-250. 